\title{
Developed a Remote Technique to Assess the Effectiveness of Thermal Insulation in Households in West Virginia
}

Prateek Vaish

Follow this and additional works at: https://researchrepository.wvu.edu/etd

\section{Recommended Citation}

Vaish, Prateek, "Developed a Remote Technique to Assess the Effectiveness of Thermal Insulation in Households in West Virginia" (2014). Graduate Theses, Dissertations, and Problem Reports. 6857. https://researchrepository.wvu.edu/etd/6857

This Thesis is protected by copyright and/or related rights. It has been brought to you by the The Research Repository @ WVU with permission from the rights-holder(s). You are free to use this Thesis in any way that is permitted by the copyright and related rights legislation that applies to your use. For other uses you must obtain permission from the rights-holder(s) directly, unless additional rights are indicated by a Creative Commons license in the record and/ or on the work itself. This Thesis has been accepted for inclusion in WVU Graduate Theses, Dissertations, and Problem Reports collection by an authorized administrator of The Research Repository @ WVU. For more information, please contact researchrepository@mail.wvu.edu. 
Developed a Remote Technique to Assess the Effectiveness of Thermal Insulation in Households in West Virginia

By

Prateek Vaish

Thesis submitted to the College of Engineering and Mineral Resources

At West Virginia University

in partial fulfillment of the requirements

for the degree of

Master of Science

in

Mechanical and Aerospace Engineering

Kenneth H Means, Ph.D, P.E

Bhaskaran Gopalakrishnan, Ph.D., P.E, CEM, CPEnMS., LEED GA

Terence Musho, Ph.D

Mechanical and Aerospace Engineering

Morgantown, West Virginia

2014

Keywords: Insulation, Response, Predictors, Empirical Equation, MLR

Copyright 2014 (Prateek Vaish) 


\author{
ABSTRACT \\ Developing a Remote Technique to Assess the Effectiveness of Thermal Insulation in \\ Households in West Virginia \\ Prateek Vaish
}

Physical energy audits and interventional methods cannot sustain the increasing demand of assessing the effectiveness of existing thermal insulation in households. As for now, there does not exist a sufficiently accurate remote technology or method to assess the efficiency of a thermal envelope. Usually, the energy bills and the age of the furnace are good indicators of the performance of insulation in houses. To overcome the lack of availability of a proper framework to calculate the effectiveness of the thermal envelope, a standard methodology using multiple linear regression and temperature data acquired from a house has been developed. The major aim of the experiment was to develop a model equation which will assess the effectiveness of insulation in a house in West Virginia. If developed futher, the model will be a very useful tool for energy auditors and consultants to help house owners understand the behavior of thermal insulation in their house.

The model requires four variables for input which are: 1) area of the house, 2) number of people in the house, 3) temperature difference (inside and ambient) and 4) air changes per hour inside the house. Extensive data acquisition was performed to develop a robust model. The model can now be used with minimum understanding of underlying concepts and can assess the effectiveness of thermal barrier which otherwise is very difficult to determine. 


\section{ACKNOWLEDGEMENT}

I would like to thank my advisor Dr. Kenneth Means and Dr Bhaskaran Gopalakrishnan for their continued support, guidance and encouragement during the course of this research. I also wish to thank Dr. Terence Musho and Mr Subodh Chaudhari for their advice and support. I wish to extend my special thanks to Dr Chris Haddox for his invaluable help and support for the success of this project.

Above all, I wish to thank God and my family for their constant support and blessings, enabling my success and happiness in all my pursuits and endeavors in life. 


\section{Nomenclature}

$\begin{array}{lll}\text { HVAC } & - & \text { Heating, Ventilation and Air Conditioning } \\ \text { ASHRAE } & - & \text { American Society of Heating Refrigeration and Air Conditioning } \\ & & \text { Engineers } \\ \text { CD }_{D} & - & \text { Drag Coefficient } \\ \text { MLR } & - & \text { Multiple Linear Regression } \\ \text { LCC } & - & \text { Life Cycle Cost } \\ \text { NC } & - & \text { Nonconformance } \\ \text { kWh } & - & \text { Kilo Watt Hour }\end{array}$




\section{Table of Contents}

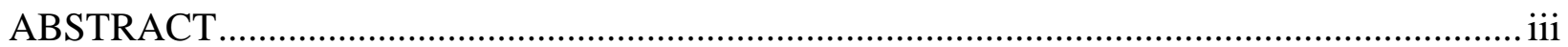

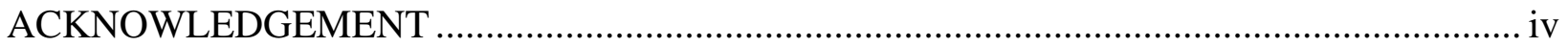

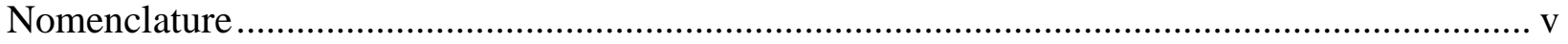

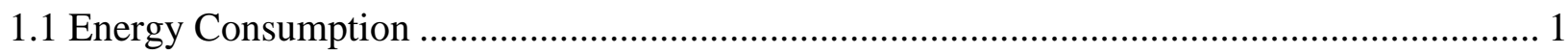

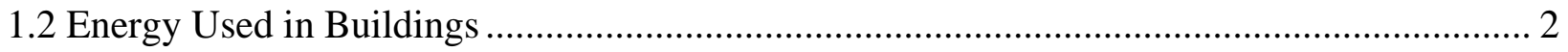

1.3 Residential Energy Consumption ....................................................................................... 3

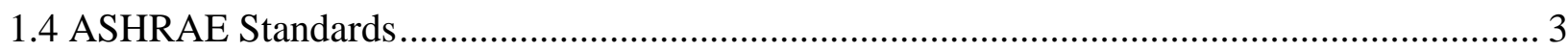

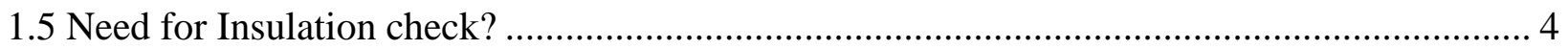

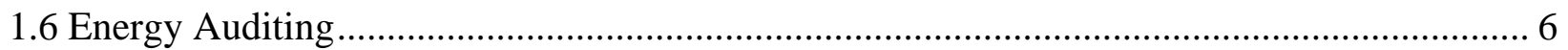

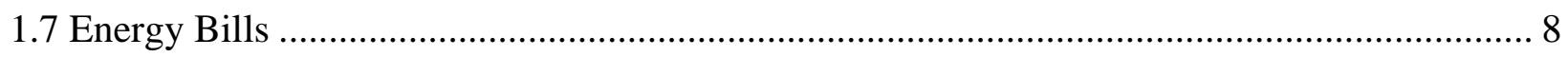

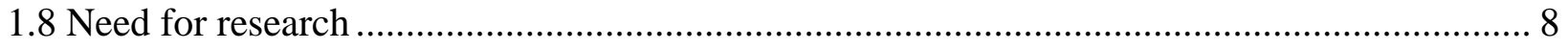

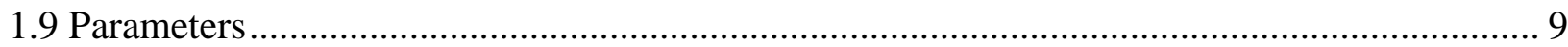

1.9.1 Actual Energy Consumption ................................................................................. 9

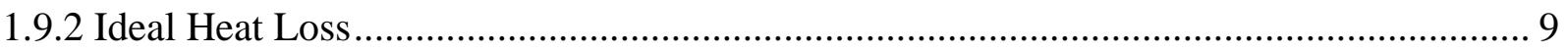

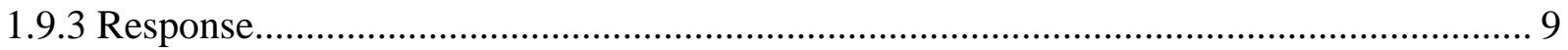

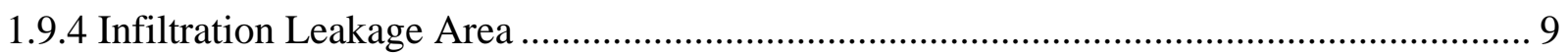

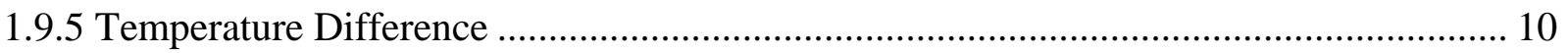

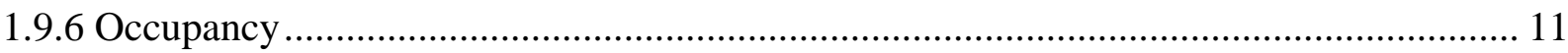

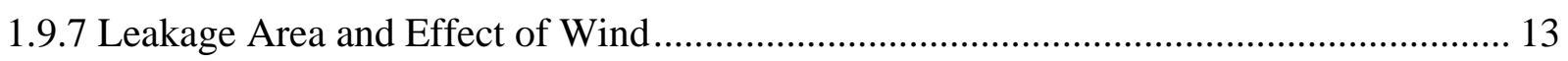

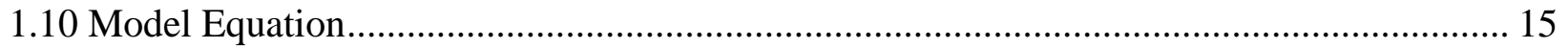

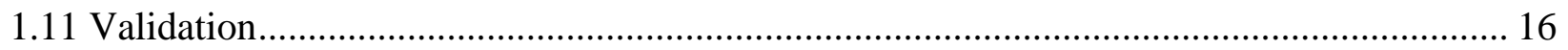

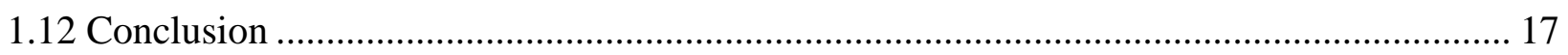

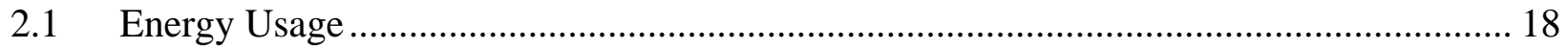

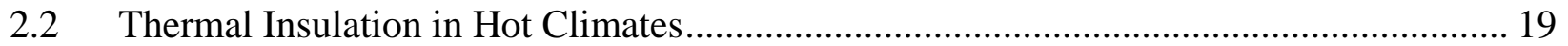

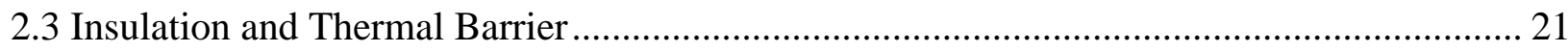

2.4 Effect on Energy Consumption........................................................................................ 24

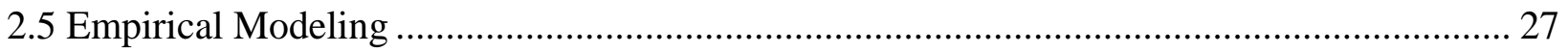

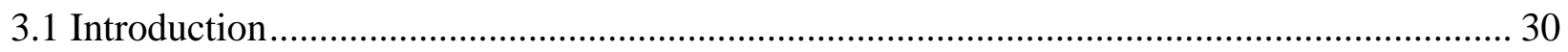

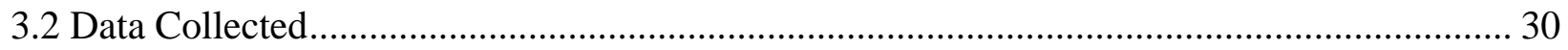

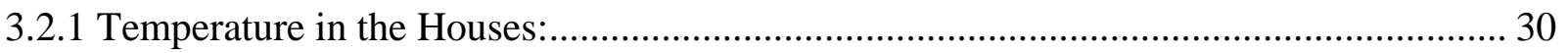


3.2.2 Weather Data.......................................................................................................... 32

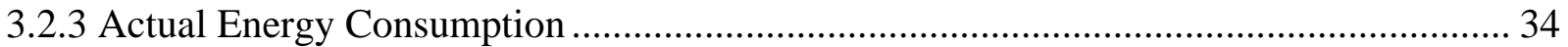

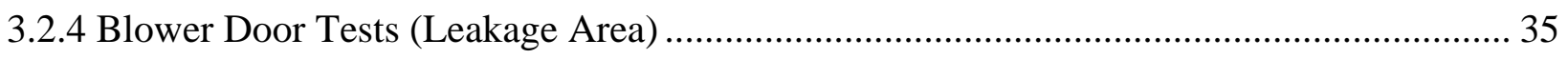

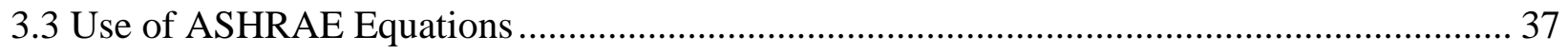

3.3.1 Heat Loss or Ideal Furnace Consumption ..................................................................... 37

3.3.2 Response

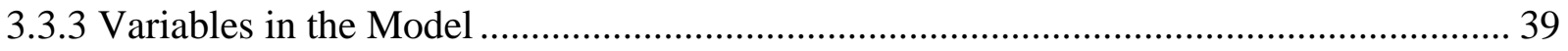

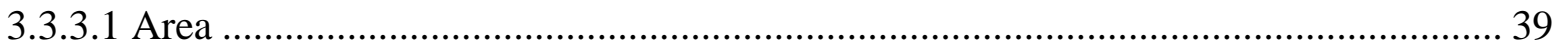

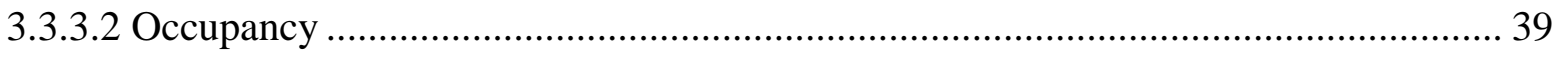

3.3.3.3 Air Changes Per Hour................................................................................. 40

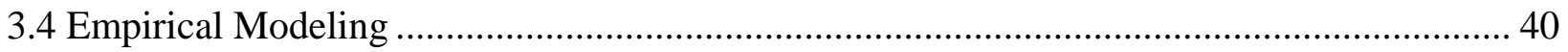

4.1 Insulation Effectiveness Study Data Analysis ...................................................................... 43

4.2 Predictors for Multiple Linear Regression.......................................................................... 44

4.3 Using Multiple Linear Regression to Determine First Order Coefficient ............................... 45

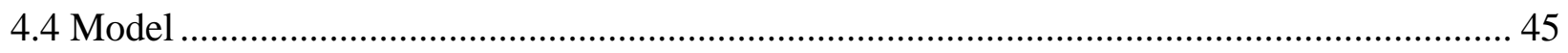

4.4.1 Final Equation, Coefficients and ANOVA ………...................................................... 49

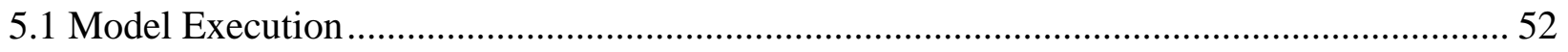

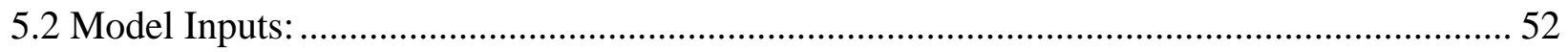

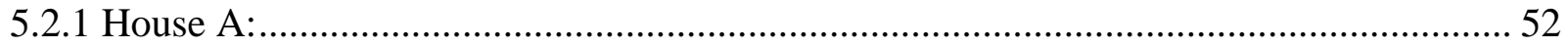

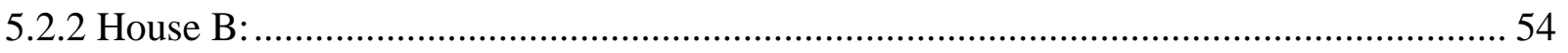

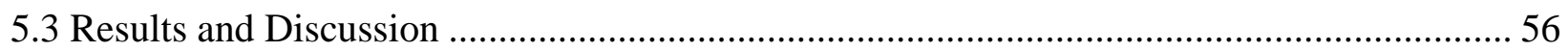

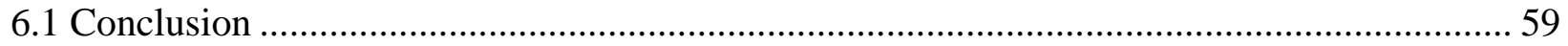

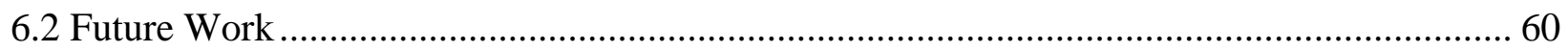




\section{List of Figures}

Figure 1.1 (a): Energy consumption in major G20 countries [2] ........................................... 1

Figure 1.1 (b): Consumption of Energy Source in US - 2009 [3] .......................................... 2

Figure 1.3: Total energy consumption in US homes: 1978 and 2005 ...................................... 3

Figure 1.4: Average Energy Consumption per Home and Number of Housing Units [6] ............ 4

Figure 1.5 (a): Average Energy Consumption per Home and Number of Housing Units [1] ........ 4

Figure 1.5 (b): Heat Loss in a House-Weatherization (Accessed from web, 01/2014) ................ 5

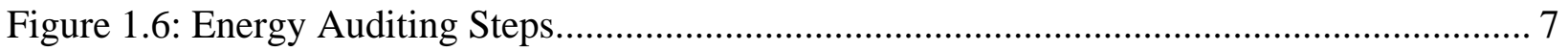

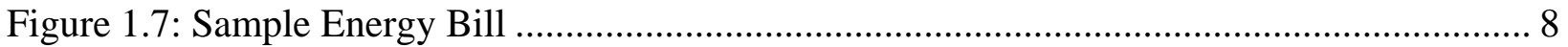

Figure 1.9.4: Effective Air Leakage Areas (Low Rise Residential Applications)..................... 10

Figure 1.9.5 Effect of lowering thermostat setpoint on heat loss ........................................ 11

Figure 1.9.6 (a): Sensible and Latent Heat Loss from People ............................................... 12

Figure 1.9.6 (b): Continuous Whole Building Ventilation Rate ............................................. 13

Figure 1.9.7 (a): Blower Door Test Setup and CFM50 Reading ............................................ 14

Figure 1.9.7 (b): Basic Model Wind and Stack Coefficients ................................................ 15

Figure 2.1: Distribution of Energy between Different Appliances[1] ..................................... 18

Figure 2.2 (a): Annual Energy Savings vs Insulation Type [13] ........................................... 19

Figure 2.2 (c): Heating demand vs wind speed with airtightness 1,3,6 with (a) mechanical exhaust only ventilation system (b) mechanical exhaust supply system ............................... 21

Figure 2.3 (a): Heat Flow through Various Thermal Insulation Systems................................ 22

Figure 2.3 (b): Various Temperatures in the House without Radiant Barrier in Summer........... 23

Figure 2.3 (d): Contour of Temperature Distribution (a) XY plane (b) YZ plane...................... 24

Figure 2.4 (a): The Effect of Occupants on Energy Usage for 1987-1988 Heating Season......... 25

Figure 2.4 (b): Temperature and Heat Gain Components of the exposed wall: (a) No insulation,

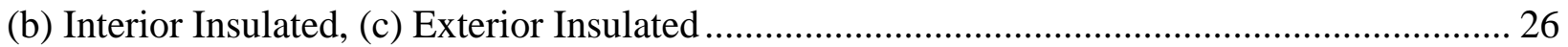

Figure 2.4 (c): Framework of Generating Typical Heating Load Profile ................................. 27

Figure 2.4 (d): Typical Heating Load Profile of a Dwelling ............................................... 27

Figure 2.5 (a): Diagram of delivered heat power in the function of outside temperature (dark line)

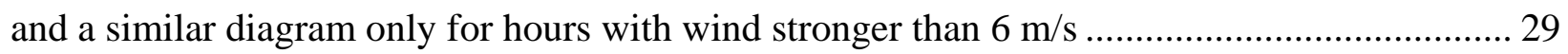

Figure 2.5 (b): Regression Result of Each User Group ..................................................... 29 
Figure 3.2.1 (a) Hourly Temperature Data in Building 775, Apt 1 ........................................ 31

Figure 3.2.1 (b) Hourly Temperature Data in Building 777, Apt 2 ..................................... 31

Figure 3.2.2 Hourly Meteorological Data by NCDC ........................................................ 33

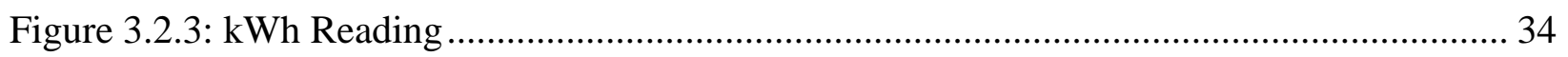

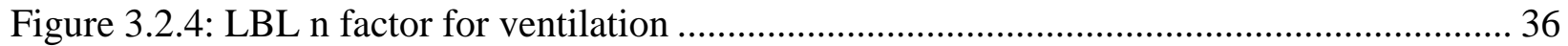

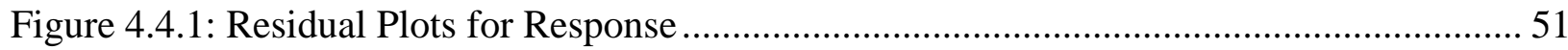




\section{List of Tables}

Table 3.2.3: kWh Usage in Residential Houses.................................................................. 35

Table 3.2.4: Air Leakage in Residential Houses.................................................................... 36

Table 3.3.3.2: Sensible and Latent Heat Loss from Human .................................................... 39

Table 3.4: Data Set for Empirical Modeling ......................................................................... 42

Table 4.4 (a): Predictand and Predictors for Multiple Linear Regression Analysis .................... 46

Table 4.4 (b): Boundary Limits for Variables in the Model ................................................. 46

Table 4.4 (b): Plots of Response (Predictand) with all the variables....................................... 48

Table 4.4.1 (a): Parameter Estimates of the Empirical Model.................................................. 50

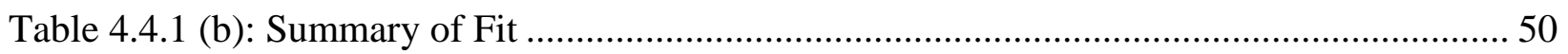

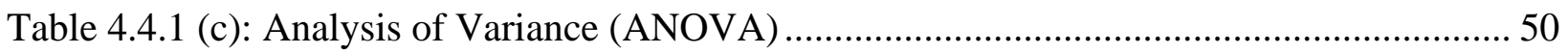

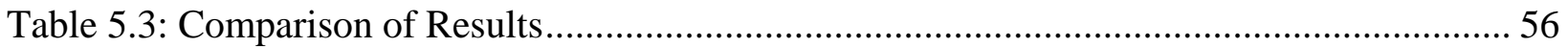

Table 6.1 (a): Effectiveness Rating in Residential Households.............................................. 58

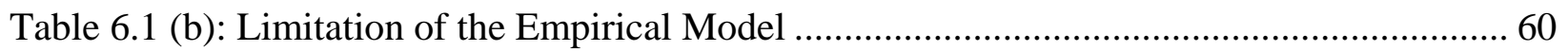




\section{Chapter 1}

\section{Introduction}

\subsection{Energy Consumption}

The energy consumption is increasing tremendously for the last four decades. The deposits of major sources of energy such as petroleum and coal are depleting at an alarming rate. It is estimated that the world energy consumption would increase by $49 \%$ from 2007 to 2035 [1]. In 2009 the world energy consumption decreased by $1.1 \%$ in comparison with 2008 . This decrease in energy consumption was observed after 30 years and was the result of the economic crisis (average GDP drop across the world by 0.6\%). Some Asian countries were not affected by recession and hence still observed increase in annual energy consumption. In North America, Europe and Commonwealth of Independent States, consumptions shrank by $4.5 \%, 5 \%$ and $8.5 \%$ respectively due to the slowdown in economic activity [1].

Due to recovery from recession and crisis, the energy consumption in Asia in 2010 increased by $5 \%$ compared to 2009 [2]. The Figure 1.1 .1 below shows the energy consumption in major G20 countries from $2008-2010$.

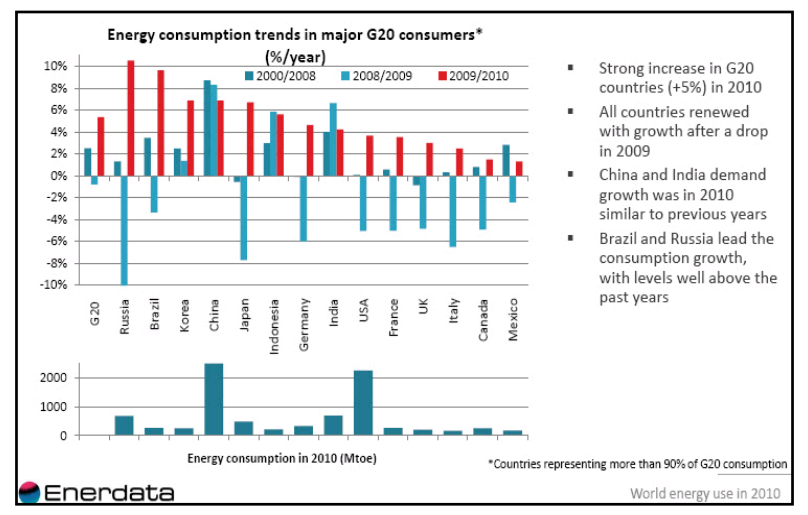

Figure 1.1 (a): Energy consumption in major G20 countries [2]

According to International Energy Agency (IEA), the world population increased by 5\%, annual $\mathrm{CO}_{2}$ emissions increased by $10 \%$ and the gross energy production increased $10 \%$ in four years (2004-2008) [2]. Despite advances in efficiency and sustainability, since the industrial revolution in the last two decades more than half of the world energy reserve has been consumed [2]. 
Till this date, dependence on oil is inevitable as an energy source even though there has been a tremendous advancement in alternate fuels. . The US consumes $25 \%$ of the world's energy with a share of global GDP at 22\% [1,2]. Figure 1.1.2 [3] shows the consumption of various energy sources in US in 2009 [Ramamoorthy, R, A Structured Approach for Facilitating the Implementation of ISO 50001 Standard in Manufacturing Industries, 2011].

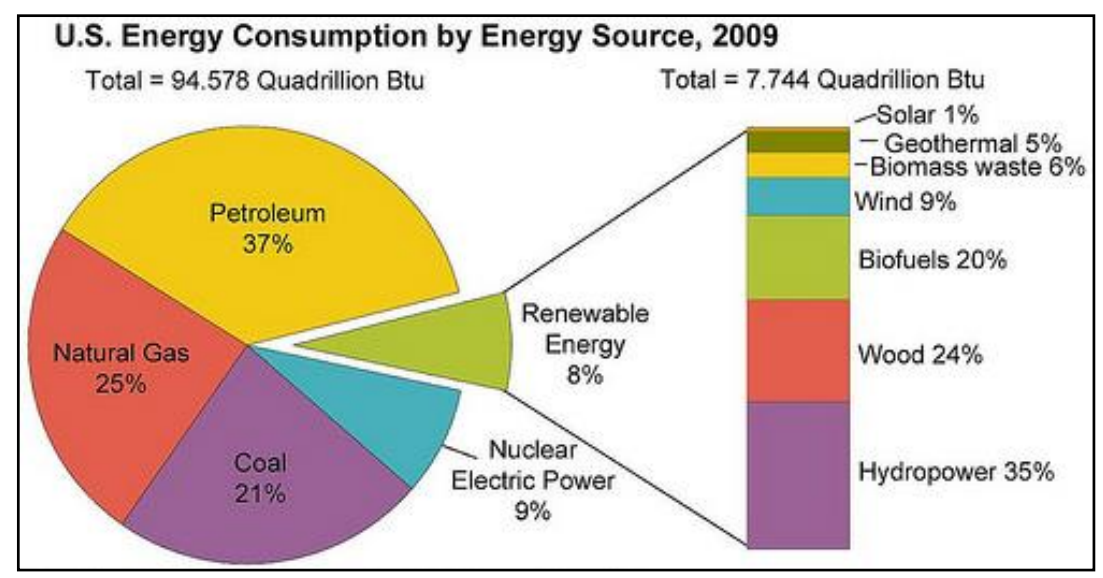

Figure 1.1 (b): Consumption of Energy Source in US - 2009 [3]

\subsection{Energy Used in Buildings}

The energy consumed by the commercial sector is almost $20 \%$ of total energy consumption in United States. The top three uses of energy uses in commercial sector are space heating, cooling and lighting comprising of more than $50 \%$ of energy usage. It was found that there was a $69 \%$ increase in the commercial floor space and 58\% increase in primary energy consumption, between the years 1980 and 2009. The EIA (Energy Information Administration), the primary energy consumption in commercial buildings will increase by $22 \%$ between the years 2009 and 2035. Commercial buildings consumed 17.9 quads of primary energy in 2009, representing $46.0 \%$ of building energy consumption and $18.9 \%$ of U.S. energy consumption. [4] 


\subsection{Residential Energy Consumption}

Residential buildings include homes, apartments and mobile homes. In the recent years, an increase in energy consumption has been noticed in residential buildings. One of the reasons for increase energy consumption is that the standard of living has been increased too in recent years. This has led to increased usage of electric appliances and HVAC applications.

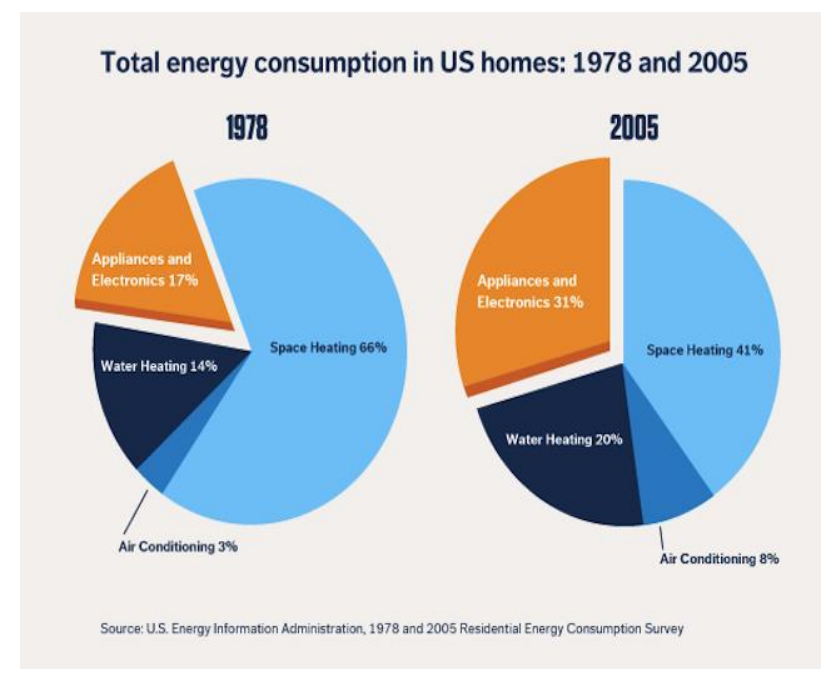

Figure 1.3: Total energy consumption in US homes: 1978 and 2005

\subsection{ASHRAE Standards}

ASHRAE 90.2 is a residential standard published by American Society of Heating, Refrigerating and Air Conditioning Engineers (ASHRAE) that provides guidance for meeting minimum energy efficiency requirements in low-rise buildings. ASHRAE 90.2 covers the seven climatic zones and has laid down 37 separate prescriptive paths. ASHRAE 90.2 energy efficient design of low rise buildings provides minimum requirement for such building designs [5]. The energy requirements are intented to be an advancement in energy efficiency, as well as being economical. Compliance is achieved through either the prescriptive or the systems analysis methods. The prescriptive criterion contains an independent energy requirement for each building component, such as exterior walls or duct insulation. This method is the easiest to use, but is the most stringent and offers the least design flexibility. The systems analysis approach bases compliance on achieving an acceptable annual energy cost for the building. This method 
requires a detailed analysis, but allows for increased design flexibility, as well as accounting for energy efficient features such as passive solar or innovative designs. [6]

Figure 1-Exterior Wall Required U-Factors

Copyright 1993 by the American Society of Heating, Refrigerating and Air-Conditioning Engineers, Inc. from ASHRAE Standard 90.2-1993. Used by permission.

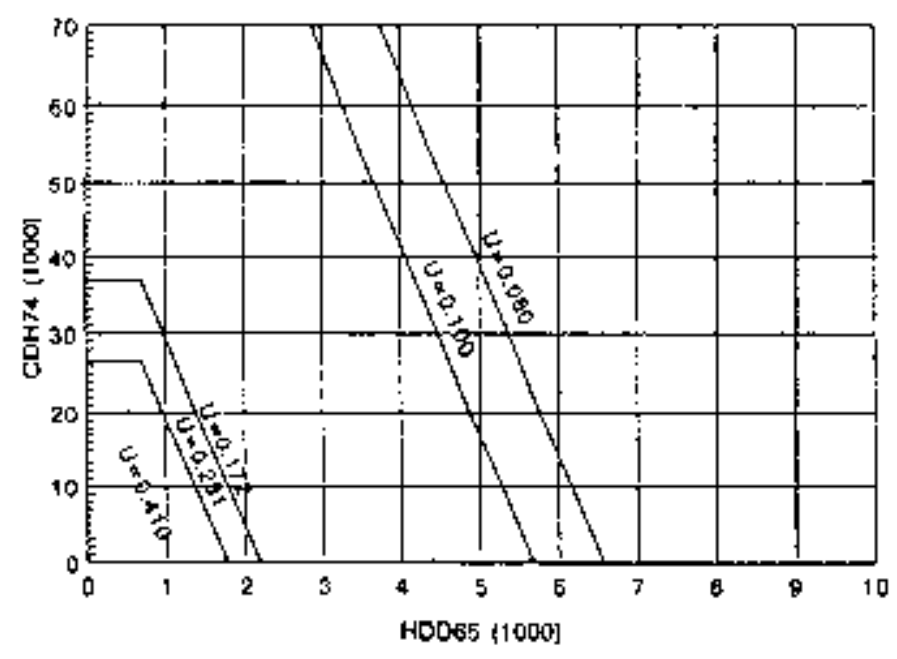

Figure 1.4: Average Energy Consumption per Home and Number of Housing Units [6]

\subsection{Need for Insulation check?}

Energy used for heating accounts for almost $41 \%$ in United States. So there is a huge opportunity for energy savings by reducing heat loss. The purpose of insulation is to reduce this heat loss in winters acting as a thermal barrier.

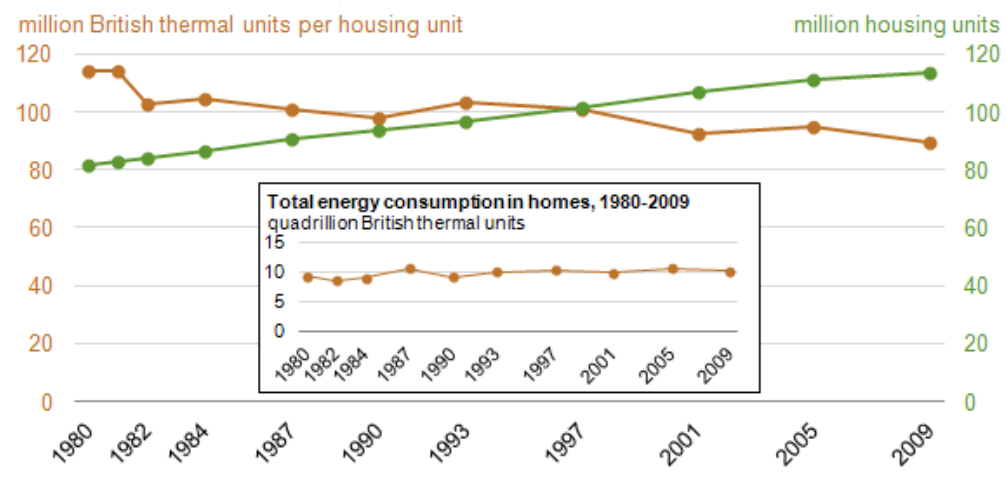

Figure 1.5 (a): Average Energy Consumption per Home and Number of Housing Units [1] 
The graph shows that the number of houses from 1980 has increased to 2009 and the energy usage per house has decreased from 1980 to 2009. Also it should be noted that the total amount of energy consumed is almost the same from 1980 to 2009. This shows that much has been done to reduce heat loss or in other words to improve insulation of a house.

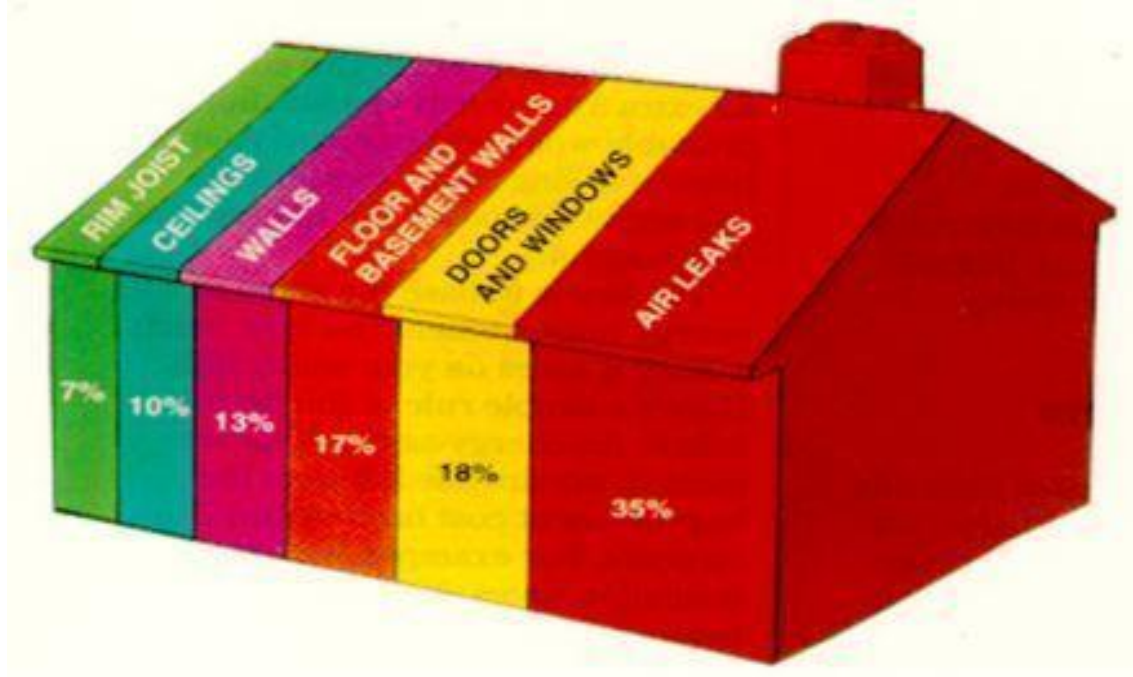

Figure 1.5 (b): Heat Loss in a House-Weatherization (Accessed from web, 01/2014)

The figure shows the places which accounts for heat loss. These areas are to be addressed while checking for insulation. The major heat loss is due to infiltration or weatherization which accounts for almost 35\% heating energy loss. Walls and floors account for $13 \%$ and $17 \%$ respectively.

Check for insulation is necessary to minimize the loss of energy from these areas. This loss can be reduced by retrofitting the insulation in various areas of the house.

In general it is more cost-effective to upgrade insulation than it is to upgrade the furnace. However, if the furnace is old, it is recommended to upgrade the furnace if you have to choose between the two options. The average lifetime for a furnace is between 15 and 20 years. The efficiency of furnaces has increased over the years, so the older the furnace, more likely it is that furnace will be inefficient. The average efficiency of new furnaces has increased from $63 \%$ (1972) to 83\% (1995). Older furnaces, and furnaces which are used a lot are more cost-effective to replace than newer or infrequently used furnaces. Also, if the house is insulated at the time of furnace replacement, it may be possible to replace the existing system with a smaller capacity 
furnace and save money on the price. The same holds true for $\mathrm{A} / \mathrm{C}$ and other heating and cooling equipment. [7]

\subsection{Energy Auditing}

A home energy audit is a process to evaluate the energy consumption in the house. This process involves the energy auditor to analyze the past year energy bills and benchmark the energy profile. The next step involves a short interview with the building / home owner about the operation schedule of the main energy consuming appliances and the problems (if any) about them. The auditor then does a walk through in the house to note down readings and install data loggers or sub-meters to calculate the energy consumed by the equipment individually.

A home energy audit also involves a blower door test to assess the leakage in the house. The major part of this process is assessing the utilization of the HVAC unit because heating and cooling comprise of more than $60 \%$ of the energy used in a residential house. The final step is to develop a comprehensive report including all the energy conservation measures and an approximate implementation cost and payback period. The figure 1.5.1 shows a flow chart of the home energy audit process. 
Figure 1.6: Energy Auditing Steps

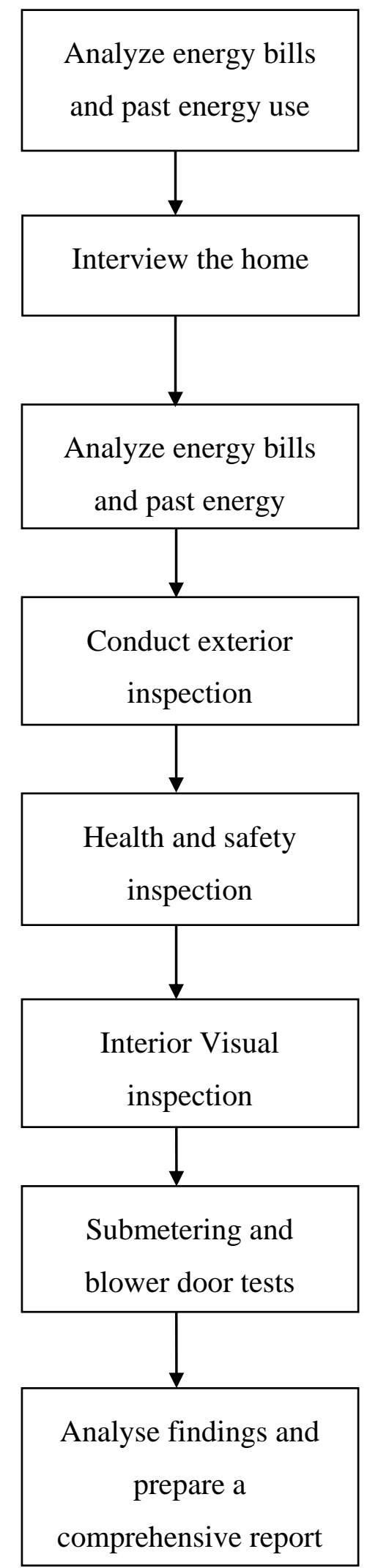




\subsection{Energy Bills}

A residential electric bill is charged according to the number of kilowatt hours of power used during a period of one or two months. And the billing amount is generated by multiplying the rate per kilowatt hour with the total kilowatt hours used. Figure 1.6.1 shows a sample electric and a gas bill.

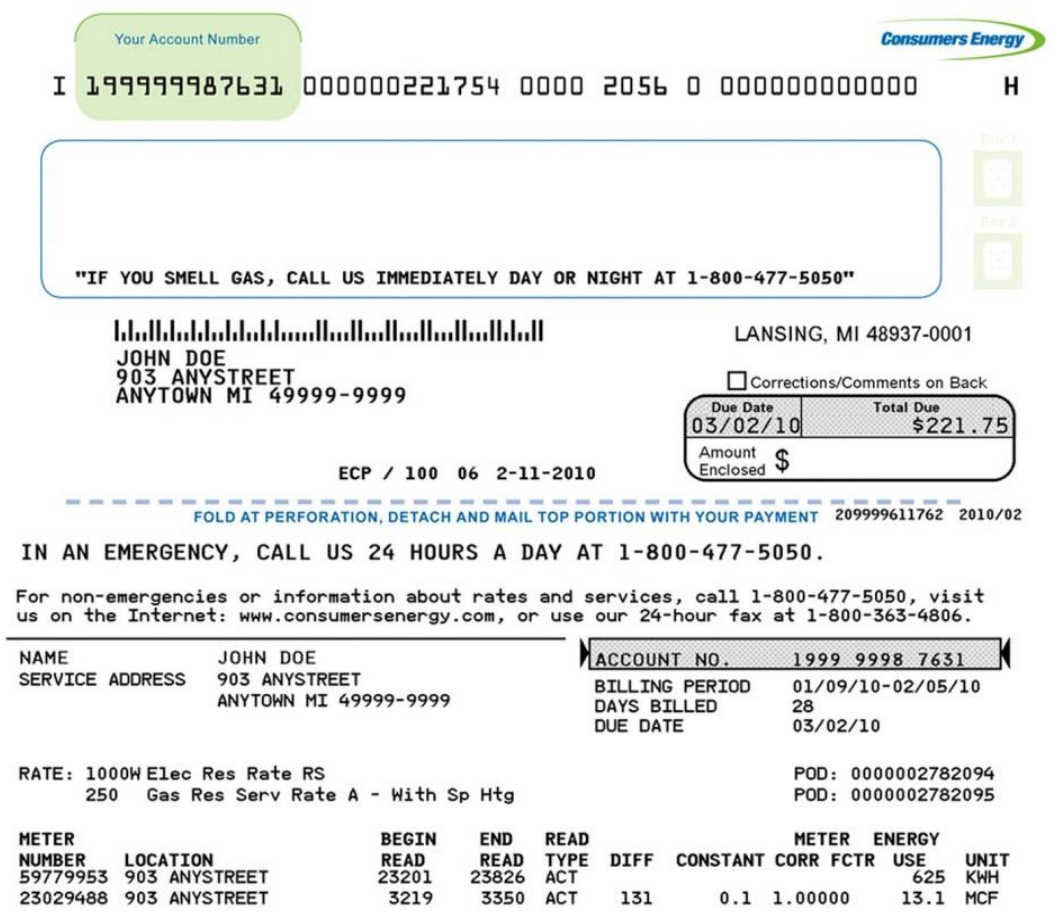

Figure 1.7: Sample Energy Bill

In this study, the readings from the electric bills and readings from actual meters are used to estimate the energy used by the HVAC units. It was estimated that the out of total electricity charge, $41 \%$ was used for space heating and out of total gas bill (if any), $60 \%$ was used for space heating.

\subsection{Need for research}

Till this date, there is no non-invasive method or straight forward formula to assess the effectiveness of the insulation of a house. The only possible way is to get an energy audit done which cost, anywhere from $\$ 300-\$ 1,000$, depending on the size of the house. So, the whole idea of this research is to do a remote audit which will include only the use of energy bills and the drawing of the house. The equation developed from this research will give a rating of the 
effectiveness of the thermal blanket of the residential house or in other words, will show how good the insulation is. This method will be very cost effective and will give an idea to the homeowner about what to do next.

\subsection{Parameters}

During this research some parameters were selected which effect the insulation or heating loads in a house. There are many factors on which the heating loads depend but due to some restrictions (explained in upcoming sections), only the following variables were taken into account:

\subsubsection{Actual Energy Consumption}

The energy used in heating is used as a reference in this study. Most of the furnaces in the experiment were electric. The $\mathrm{kWh}$ readings were taken from the utility meters. At the end of experiment the difference of readings from the first day and the last day was used as the actual energy consumption.

\subsubsection{Ideal Heat Loss}

The ideal heat loss is the energy loss from a residential house. This loss is calculated by International Energy Conservation Code (IECC) standards for Monongalia County, WV. This heat loss takes into account the design and size of the house and the $R$ values and $U$ values described the code.

The standard also takes into account the orientation of the windows and doors for solar heat gain. In this study, these variations are assumed to be same for all houses.

\subsubsection{Response}

Response is the ratio of ideal heat loss and the actual energy consumption. The response signifies the effectiveness of the thermal envelope in the house. It gives an idea of how well the house is insulated and if there is a need to make some changes regarding the same.

\subsubsection{Infiltration Leakage Area}

The area of the house is usually directly proportional to the leakage area of the house but this cannot be generalized as the leakage area is also dependent on the make of the house, climatic 
conditions and the yearly maintenance done in the house. ASHRAE Fundamentals Handbook 1997 has specified some values for effective leakage area according to the size and type of walls, roof, floor, windows, electric sockets, doors and vents. These values hold good for low-rise buildings. The effective air leakage area is based on a pressure difference of 0.016 in of water and a $C_{D}$ (drag coefficient) of 1 . So, if estimation has to be made according to the ASHRAE handbook, the leakage will be more if the size of the house is more.

\begin{tabular}{|c|c|c|c|c|}
\hline & Units & Best Estimate & Minimum & Maximum \\
\hline $\begin{array}{c}\text { Ceiling } \\
\text { Woor Frame, }\end{array}$ & in2/ft2 & 0.026 & 0.011 & 0.04 \\
\hline Door, General & in2/ft2 & 0.004 & 0.001 & 0.004 \\
\hline Electrical outlets & in2/ea & 0.023 & 0.012 & 0.021 \\
\hline Ceiling-wall & in2/lfte & 0.07 & 0.0075 & 0.12 \\
\hline joint & in2/ea & 1.6 & 0.39 & 3.1 \\
\hline $\begin{array}{c}\text { Walls, clay brick } \\
\text { cavity wall }\end{array}$ & in2/ft2 & 0.0098 & 0.0007 & 0.033 \\
\hline Windows, not & in2/ft2 & 0.023 & 0.011 & 0.035 \\
\hline
\end{tabular}

Figure 1.9.4: Effective Air Leakage Areas (Low Rise Residential Applications)

\subsubsection{Temperature Difference}

Temperature difference plays a very significant role in determining the effectiveness of the insulation. Temperature difference is calculated by recording the temperatures inside and outside the house. The temperature inside the house is governed by the set point temperature and the temperature inside the house depends on all the factors mentioned above. Figure 1.9.5 shows a graph between heat loss and the set point temperature. 


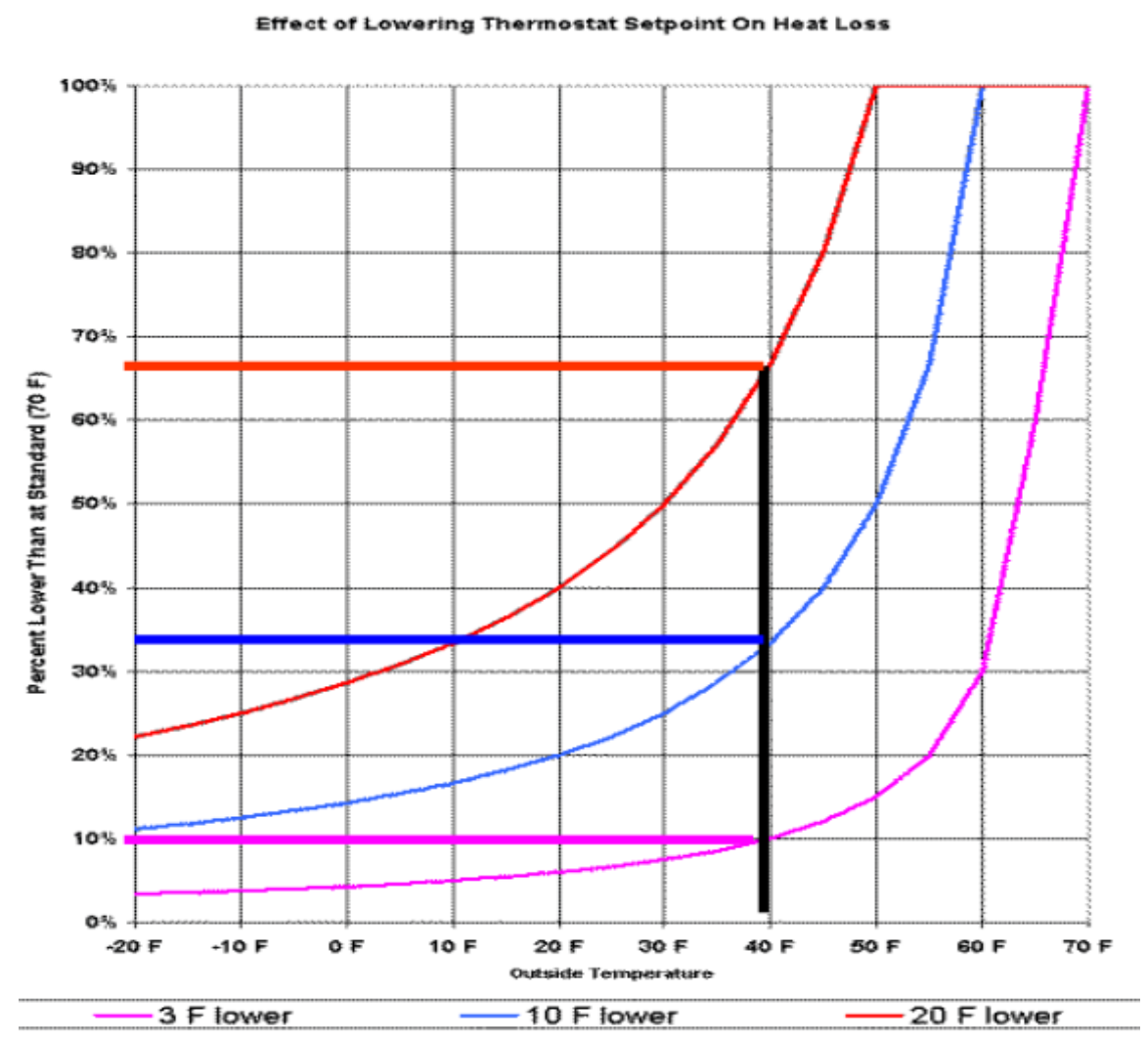

Figure 1.9.5 Effect of lowering thermostat setpoint on heat loss

The graph shows that there is a significant decrease in heat loss as the set temperature is decreased [8]. Decreasing the set point temperature will decrease the temperature inside the house which will bring down the temperature difference. As the temperature difference is decreased, assuming all conditions remain same, the heat loss will be decreased.

\subsubsection{Occupancy}

Metabolic functions dissipate heat from the human body into the rooms in the form of latent heat and sensible heat. The heat from convection and radiation is sensible heat and the heat from evaporation is known as latent heat. Under normal conditions the rate of heat transfer from a human body varies from $100 \mathrm{~W}$ at sedentary conditions to 1,000 watt at high physical work conditions. 


\begin{tabular}{|c|c|c|c|c|c|c|c|c|c|c|c|c|c|c|}
\hline \multirow{3}{*}{$\begin{array}{c}\text { Degree of } \\
\text { Activity }\end{array}$} & \multirow{3}{*}{$\begin{array}{c}\text { Typical } \\
\text { Application }\end{array}$} & $\begin{array}{c}\text { Average } \\
\text { Metabolic } \\
\text { rate - }\end{array}$ & \multicolumn{12}{|c|}{ Room Dry Bulb Temperature $\left({ }^{\circ} \mathrm{C}\right)$} \\
\hline & & $(W)$ & \multicolumn{2}{|c|}{28} & \multicolumn{2}{|c|}{27} & \multicolumn{2}{|c|}{26} & \multicolumn{2}{|c|}{24} & \multicolumn{2}{|c|}{22} & \multicolumn{2}{|c|}{20} \\
\hline & & & Sens. & Lat. & Sens. & Lat. & Sens. & Lat. & Sens. & Lat. & Sens. & Lat. & Sens. & Lat. \\
\hline $\begin{array}{c}\text { Seated at } \\
\text { rest }\end{array}$ & $\begin{array}{l}\text { Cinema, } \\
\text { theatre, } \\
\text { school }\end{array}$ & 100 & 50 & 50 & 55 & 45 & 60 & 40 & 67 & 33 & 72 & 28 & 79 & 21 \\
\hline $\begin{array}{l}\text { Seated, } \\
\text { very light } \\
\text { work }\end{array}$ & $\begin{array}{l}\text { Computer } \\
\text { working }\end{array}$ & 120 & 50 & 70 & 55 & 65 & 60 & 60 & 70 & 50 & 78 & 42 & 84 & 36 \\
\hline $\begin{array}{l}\text { Office } \\
\text { work }\end{array}$ & $\begin{array}{l}\text { Hotel } \\
\text { reception, } \\
\text { cashier }\end{array}$ & 130 & 50 & 80 & 56 & 74 & 60 & 70 & 70 & 60 & 78 & 52 & 86 & 44 \\
\hline $\begin{array}{c}\text { Standing, } \\
\text { walking } \\
\text { slowly }\end{array}$ & $\begin{array}{l}\text { Laboratory } \\
\text { work }\end{array}$ & 130 & 50 & 80 & 56 & 74 & 60 & 70 & 70 & 60 & 78 & 52 & 86 & 44 \\
\hline $\begin{array}{c}\text { Walking, } \\
\text { seated }\end{array}$ & & 150 & 53 & 97 & 58 & 92 & 64 & 86 & 76 & 74 & 84 & 66 & 90 & 60 \\
\hline $\begin{array}{c}\text { Moderate } \\
\text { work }\end{array}$ & $\begin{array}{c}\text { Servant, hair } \\
\text { dresser }\end{array}$ & 160 & 55 & 105 & 60 & 100 & 68 & 92 & 80 & 80 & 90 & 70 & 98 & 62 \\
\hline $\begin{array}{l}\text { Light } \\
\text { bench } \\
\text { work }\end{array}$ & $\begin{array}{l}\text { Mechanical } \\
\text { production }\end{array}$ & 220 & 55 & 165 & 52 & 158 & 70 & 150 & 85 & 135 & 100 & 120 & 115 & 105 \\
\hline $\begin{array}{c}\text { Moderate } \\
\text { Dancing }\end{array}$ & Party & 250 & 62 & 188 & 70 & 180 & 78 & 172 & 94 & 156 & 110 & 140 & 125 & 125 \\
\hline $\begin{array}{c}\text { Fast } \\
\text { walking }\end{array}$ & $\begin{array}{l}\text { Mountain } \\
\text { walking }\end{array}$ & 300 & 80 & 220 & 88 & 212 & 96 & 204 & 110 & 190 & 130 & 170 & 145 & 155 \\
\hline $\begin{array}{c}\text { Heavy } \\
\text { work }\end{array}$ & Athletics & 430 & 132 & 298 & 138 & 292 & 144 & 286 & 154 & 276 & 170 & 260 & 188 & 24 \\
\hline
\end{tabular}

Figure 1.9.6 (a): Sensible and Latent Heat Loss from People

Though the heating load should decrease with increase in number of people, as it will account for more and more heat but it also increases the amount of carbon dioxide and thus it increases the air changes per hour. Thus the heating unit has to work more to meet the ventilation demands. 


\begin{tabular}{|c|c|c|c|c|c|}
\hline \multicolumn{6}{|c|}{$\begin{array}{l}\text { ASHRAE Standard } 62.2 \text { Table } 4.1 \mathrm{a} \\
\text { Continuous Whole-Building Ventilation Rate in cfm }\end{array}$} \\
\hline \multirow{2}{*}{$\begin{array}{l}\text { Floor } \\
\text { Area } \\
\text { (sq ft) }\end{array}$} & \multicolumn{5}{|c|}{ Number of Bedrooms } \\
\hline & 0 - 1 & 3-Feb & 5-Apr & 7-Jun & $>7$ \\
\hline$<1500$ & 30 & 45 & 60 & 75 & 90 \\
\hline $\begin{array}{l}1501- \\
3000\end{array}$ & 45 & 60 & 75 & 90 & 105 \\
\hline $\begin{array}{l}3001- \\
4500\end{array}$ & 60 & 75 & 90 & 105 & 120 \\
\hline $\begin{array}{l}4501- \\
6000\end{array}$ & 75 & 90 & 105 & 120 & 135 \\
\hline $\begin{array}{l}6001- \\
7500\end{array}$ & 90 & 105 & 120 & 135 & 150 \\
\hline$>7500$ & 105 & 120 & 135 & 150 & 165 \\
\hline
\end{tabular}

Figure 1.9.6 (b): Continuous Whole Building Ventilation Rate

\subsubsection{Leakage Area and Effect of Wind}

Leakage area of the house was measured by performing blower door tests. A blower door is a diagnostic tool to assess the air tightness of a house. The test consists of a blower fan which is calibrated and is fitted on the outside door of the house. The door is sealed by a thick cloth as shown in the figure. Before, turning the fan ON, the HVAC unit is turned off, all the vents, windows and openings of the house are sealed with a duct tape. Then the fan is turned on and it creates a pressure difference by blowing the air out of the house. This pressure difference forces air through all holes and penetrations in the building. The reading noted when the pressure becomes $-50 \mathrm{~Pa}$ is known as $\mathrm{CFM}_{50}$. The $\mathrm{CFM}_{50}$ can be used to calculate the $\mathrm{ACH}$ at natural conditions which is further explained in chapter 3. 

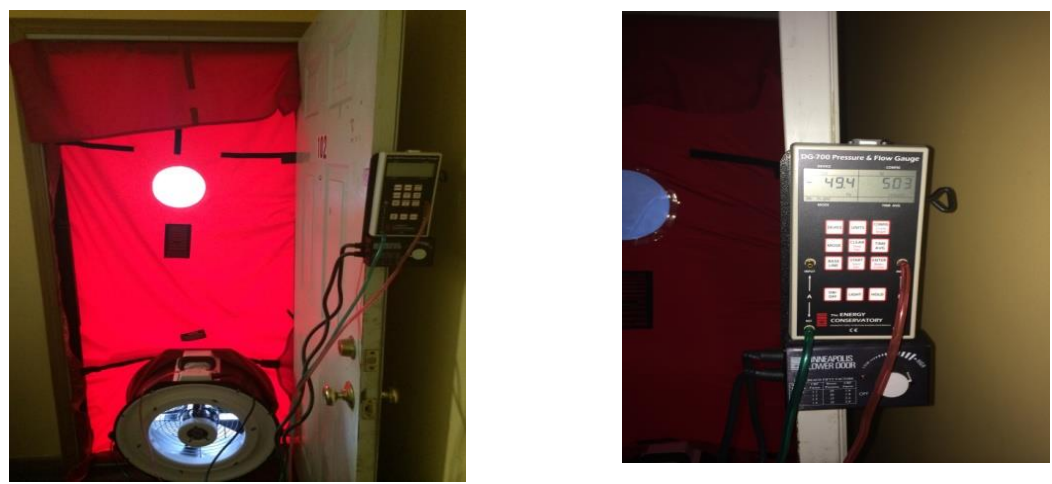

Figure 1.9.7 (a): Blower Door Test Setup and CFM50 Reading

Air infiltration rate can vary from $0.1 \mathrm{ACH}$ to $1.5 \mathrm{ACH}$ depending on the weather conditions. Air infiltration depends on air leakage, pressure difference cause by temperature difference and forces of the wind.

$$
Q=\frac{A C H \cdot A \cdot H}{60}
$$

Where,

$$
\begin{array}{ll}
\mathrm{ACH} & =\text { Air changes per hour } \\
\mathrm{A} & =\text { Area }, \mathrm{ft}^{2} \\
\mathrm{H} & =\text { Height }, \mathrm{ft} \\
\mathrm{Q} & =\text { cubic feet per minute of air }
\end{array}
$$

The speed of wind has a considerable effect on the infiltration rate in the houses. At low wind speeds infiltration occurs mostly via stack effect and at high wind speeds, the enhanced air infiltration is driven by wind and temperature effect [9].

$$
\mathrm{Q}=A_{L} \cdot \sqrt{C s \cdot \Delta T+C w \cdot U^{2}}
$$




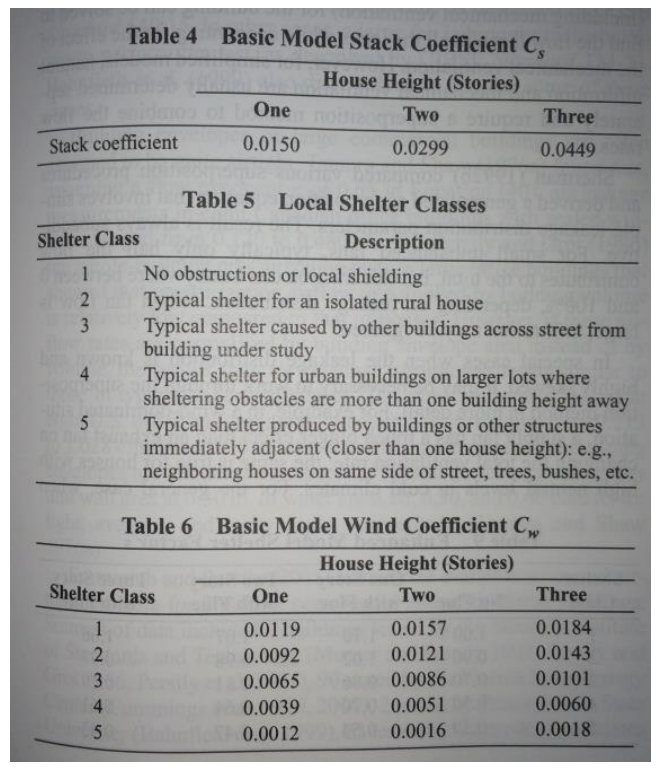

Figure 1.9.7 (b): Basic Model Wind and Stack Coefficients

Where,

$$
\begin{aligned}
& \mathrm{A}_{\mathrm{L}}=\text { Leakage area }, \mathrm{in}^{2} \\
& \mathrm{C}_{\mathrm{S}}=\text { Stack Coefficient } \\
& \Delta T=\text { Temperature Difference } \\
& \mathrm{CW}_{\mathrm{W}}=\text { Wind Coefficient } \\
& \mathrm{U}=\text { Wind Velocity, } \mathrm{mph}
\end{aligned}
$$

As seen in the equations, the frequency of opening and closing of the doors in the house will have an effect on heat loss depending on the average velocity of wind. It will also depend on the pressure difference (inside and outside the house) which is the stack effect

\subsection{Model Equation}

After the data collection and calculations, the final variables are as follows:
a) Response (Ideal energy consumption/Actual Energy consumption)
b) Area of the House
c) Temperature Difference
d) Number of Occupants
e) Air Changes Per Hour 
A statistical technique known as multiple linear regression is utilized in this experiment to establish a relationship between these variables and the response. Multiple linear regression models the relationship of all the variables and response by fitting a linear equation between the observed data. The dependent variable is called a predictand (response) and the independent variable is known as the predictor. Multiple Regression is based on the method of least squares, in which the best fitted of the data is obtained my minimizing the sum of least squares of the vertical deviations from each data point. [10]

It is recommended to use 4-5 data points for every variable in the equation for statistical modeling. In this model, the equation was developed using 15 data points and it was found the adjusted coefficient of determination was a significant value and validation examples yielded satisfactory results.

Multiple Regression is not a time series method and the variables are sometimes not independent of each other. [11] The following equation illustrates the multiple regression model with two variables which describes a space in three dimensional space of $\mathrm{Y}, \mathrm{X}_{1}$ and $\mathrm{X}_{2}$ :

$$
Y=\beta_{0}+\beta_{1} X_{1}+\beta_{2} X_{2}+\varepsilon
$$

Where,

$$
\begin{aligned}
& \beta_{0}=\text { Intercept of the plane } \\
& \beta_{1}=\text { Partial Regression Coefficient } \\
& \beta_{2}=\text { Partial Regression Coefficient } \\
& \beta_{3}=\text { Partial Regression Coefficient } \\
& \beta_{4}=\text { Partial Regression Coefficient }
\end{aligned}
$$

In the experiment, the final regression equation will be:

$$
\mathrm{R}=\beta_{0}+\beta_{1} \text {.Area }+\beta_{2} \text {.Temp Diff }+\beta_{3} \text {. Occupants }+\beta_{4} \text {.ACH }
$$

It should be noted that the wind speed data is used from the National Climate Data Center website and all data points have same value of wind speed. Due to this reason the wind speed is rendered insignificant in the regression analysis but practically it is significant [10].

\subsection{Validation}

The model will be validated by populating the equation by data collected again from the houses of the same buildings or different buildings. The purpose of this test will be to compare the actual energy consumption ( $\mathrm{kWh}$ ) with the values predicted by the model equation. 
The energy consumption value predicted by the model will be for nine days because the test has been done for nine days. If the both the values are in closed proximity and in an error range of 0.2 , the model will be considered valid for climatic zone 5 in heating season.

\subsection{Conclusion}

The equation obtained after the multiple regression analysis concludes that, by knowing the temperature difference for a period of 5-6 days and and some minimal data for a residential house in climate zone 5 in North America, the effectiveness of the insulation or the thermal envelope can be calculated.

This study is limited to zone 5 because all the data is collected from Morgantown, WV region and it is still not established how the equation will behave if it is used in any other part of the world except zone 5. One more limitation to this study is that it can only be used in residential

houses which have their dedicated heating units unlike in commercial buidings which have centralized heating/cooling units. 


\section{Chapter 2}

\section{Literature Review}

This chapter discusses the existing research work in understanding the creep phenomena. Different testing methodologies and various kinds of equipment's which evolved over the years in unconfined and confined conditions are also summarized.

\subsection{Energy Usage}

Most of the energy use in a household in America is being used in heating or cooling. One of the reasons for this high energy percentage of heating and cooling can be inadequate or ineffective insulation.

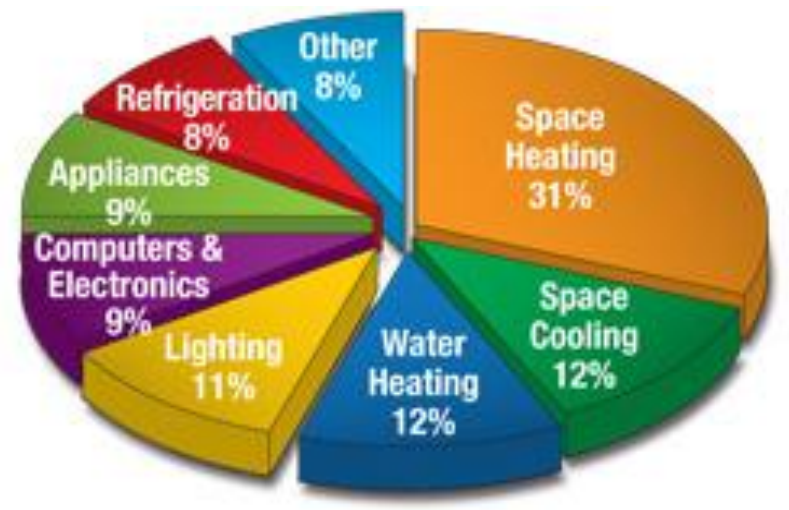

Figure 2.1: Distribution of Energy between Different Appliances[1]

The effectiveness of insulation is dependent on various factors. The main factors are type of insulation, climate, air infiltration in the house, type of heating system, age of heating system, physical activity in the house and number of people living in the house.

Insulation works by limiting the air movement between two boundaries. Batts, blankets, loose fill and low density foams, all serve this purpose. Air sealing also acts as an effective insulator by restricting air movement and prevents convection and also prevents water vapor to enter the wall[2]. 


\subsection{Thermal Insulation in Hot Climates}

The insulation is not necessarily better if it is thicker. It has to be of the right material and right thickness. In an experiment to find the effectiveness of thermal insulation in different buildings with no insulation was simulated using the Enerwin Hourly Building Energy Simulation Program[12] and different types of insulations were added in the simulation. The experiment was carried out in two different climatic zones, one being a hot-arid and other being a hot humid in middle east Asia. The Life Cycle Cost (LCC) analysis was also done with following functions:

- Building type

- Type and cost of insulation

- Cost of Energy (the value of energy saved) [13]

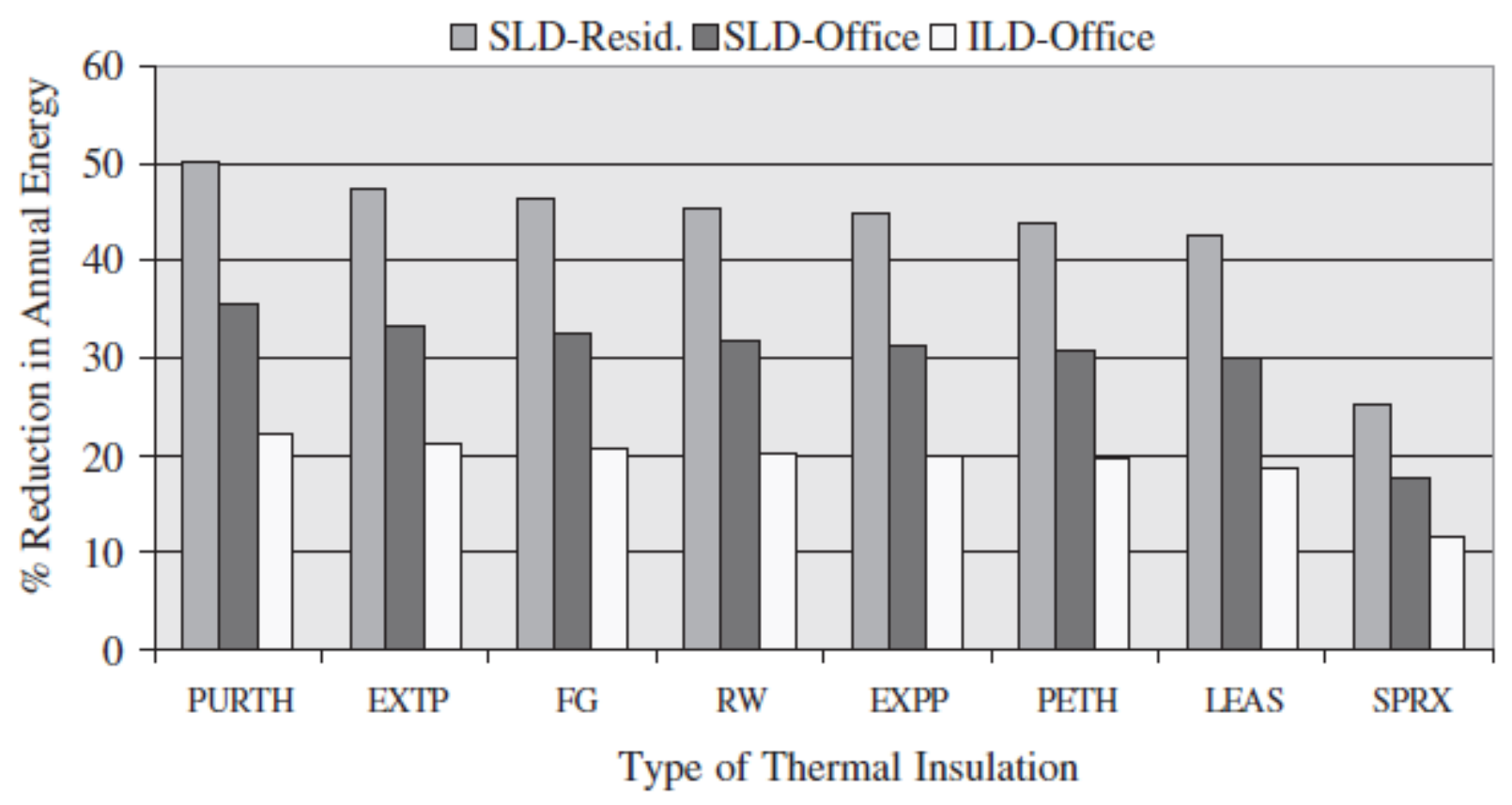

Figure 2.2 (a): Annual Energy Savings vs Insulation Type [13]

The table shows the percentage of reduction in cooling load with different insulations. The results from this experiment clearly show a distinct amount of reduction in energy usage by using insulation for walls and roofs in the residential and office buildings. Also, this research concluded that by using building envelope insulations there will be cost savings as a smaller HVAC system will be required due to reduced cooling loads. 
Kashiwagi and Moor (1993) investigated the relationship between energy cost, insulation and its design [14] using Porter's Value Chain Analysis [15]. Two models were developed during this study, the first one is an analysis of effects of building configuration and environmental factors and the second one deals with energy savings and the equivalent uniform annual cost (EUAC) of roofing systems. The factors which were investigated were:

- $\mathrm{R}$ value of insulation and overall $\mathrm{R}$-value of building insulation

- Cost of heating and cooling facilities

- Outside and inside temperatures

- Window areas and building component infiltration points

\begin{tabular}{|c|c|c|c|c|c|}
\hline \multicolumn{3}{|c|}{ Location-Phoenix, AZ } & \multicolumn{3}{|c|}{ Locotion-Eau Cloir, WI } \\
\hline \multicolumn{6}{|c|}{ Effect of Energy Cout } \\
\hline $\begin{array}{c}\text { Energy Cost } \\
\text { (Times) }\end{array}$ & EUAC* & Payback & $\begin{array}{c}\text { Energy Cost } \\
\text { [Times] }\end{array}$ & EUAC & Payback \\
\hline $\begin{array}{l}1.0 \\
1.5 \\
2.0 \\
2.5 \\
3.0 \\
3.5\end{array}$ & $\begin{array}{l}0.34 \\
0.33 \\
0.33 \\
0.33 \\
0.32 \\
0.32\end{array}$ & $\begin{array}{l}19 \\
18 \\
18 \\
17 \\
16 \\
16\end{array}$ & $\begin{array}{l}1.0 \\
1.5 \\
2.0 \\
2.5 \\
3.0 \\
3.5\end{array}$ & $\begin{array}{l}0.29 \\
0.29 \\
0.29 \\
0.29 \\
0.29 \\
0.29\end{array}$ & $\begin{array}{l}13 \\
13 \\
13 \\
13 \\
12 \\
12 \\
\end{array}$ \\
\hline \multicolumn{6}{|c|}{ EFfect of PUF Thickness } \\
\hline PUF (in) & EUAC & Paybock & PUF (in) & EUAC & Poyback \\
\hline $\begin{array}{l}1.0 \\
1.5 \\
2.0\end{array}$ & $\begin{array}{l}0.29 \\
0.34 \\
0.39\end{array}$ & $\begin{array}{r}12 \\
19 \\
\mathrm{~N} / \mathrm{A}\end{array}$ & $\begin{array}{l}1.0 \\
1.5 \\
2.0\end{array}$ & $\begin{array}{l}0.26 \\
0.29 \\
0.33\end{array}$ & $\begin{array}{l}10 \\
13 \\
18\end{array}$ \\
\hline \multicolumn{6}{|c|}{ Effect of Service Lite } \\
\hline $\begin{array}{l}\text { Service life } \\
\text { (yrs) EUAC, }\end{array}$ & 1-inch & 1.5-inch & $\begin{array}{l}\text { Service life } \\
\text { (yrs) EUAC }\end{array}$ & 1-inch & 1.5-inch \\
\hline $\begin{array}{l}10 \\
15 \\
20 \\
25 \\
30\end{array}$ & $\begin{array}{l}0.36 \\
0.31 \\
0.29 \\
0.28 \\
0.28\end{array}$ & $\begin{array}{l}0.43 \\
0.36 \\
0.34 \\
0.33 \\
0.32\end{array}$ & $\begin{array}{l}10 \\
15 \\
20 \\
25 \\
30\end{array}$ & $\begin{array}{l}0.34 \\
0.28 \\
0.26 \\
0.25 \\
0.25\end{array}$ & $\begin{array}{l}0.38 \\
0.32 \\
0.29 \\
0.28 \\
0.28\end{array}$ \\
\hline \multicolumn{6}{|c|}{ Effect of Design R.Value } \\
\hline $\begin{array}{l}\text { R.value } \\
\text { (Times) }\end{array}$ & EUAC & Porback & $\begin{array}{l}\text { R.Value } \\
\text { (Times) }\end{array}$ & EUAC & Poyback \\
\hline $\begin{array}{l}0.8 \\
0.9 \\
1.0 \\
1.1 \\
1.2\end{array}$ & $\begin{array}{l}0.34 \\
0.34 \\
0.34 \\
0.34 \\
0.33\end{array}$ & $\begin{array}{l}21 \\
20 \\
19 \\
19 \\
19\end{array}$ & $\begin{array}{l}0.8 \\
0.9 \\
1.0 \\
1.1 \\
1.2\end{array}$ & $\begin{array}{l}0.31 \\
0.30 \\
0.29 \\
0.29 \\
0.28\end{array}$ & $\begin{array}{l}14 \\
13 \\
13 \\
12 \\
12\end{array}$ \\
\hline \multicolumn{6}{|c|}{ Effect of PUF Installation Cost } \\
\hline $\begin{array}{c}\text { Covt } \\
\text { (Times) }\end{array}$ & EUAC & Poyback & $\begin{array}{c}\text { Cost } \\
\text { (Times) }\end{array}$ & EUAC & Poyback \\
\hline $\begin{array}{l}0.90 \\
1.00 \\
1.50\end{array}$ & $\begin{array}{l}0.30 \\
0.34 \\
0.52\end{array}$ & $\begin{array}{r}13 \\
19 \\
\text { Nin }\end{array}$ & $\begin{array}{l}0.90 \\
1.00 \\
1.50\end{array}$ & $\begin{array}{l}0.26 \\
0.29 \\
0.47\end{array}$ & $\begin{array}{l}10 \\
13 \\
\text { NMA }\end{array}$ \\
\hline
\end{tabular}

Figure 2.2 (b): Sensitivity Analysis for PUF on Concrete Deck [14] 
The results of this study indicate that a thickness of 1.5 inches of Poly Urethane Foam (PUF) is best suitable and economic for Phoenix, AZ. Whereas in Eau Clair, WI the most economic thickness of PUF as insulation is one inch. Now for the cost analysis, it was calculated that, by increasing the thickness of PUF to 1.5 inch, it will ensure better period of service. But, the net loss will still be $\$ 0.02 / \mathrm{ft}^{2} / \mathrm{yr}$ and $\$ 0.04 / \mathrm{ft}^{2} / \mathrm{yr}$ for Eau Clair and Phoenix respectively. By the EAUC analysis it was observed that there was $\$ 0.02 / \mathrm{ft}^{2} / \mathrm{yr}$ for an increase of $350 \%$ in energy costs of the waterproofing/insulation system for Phoenix, AZ. However, no savings were observed for Eau Clair, WI as energy cost was not a significant factor while considering waterproofing/insulation alternatives. It was also noted during the study that the service factor has a big impact on savings.

Mattson studied the influence of wind speed and other factors on the air change rate of single family house. The paper concludes that stack effect is very minimal in tight houses with exhaustonly ventilation system and is influential in exhaust-supply system. The reason for houses with exhaust-supply system, more sensitive to wind speed is due to the inlet vents [16].
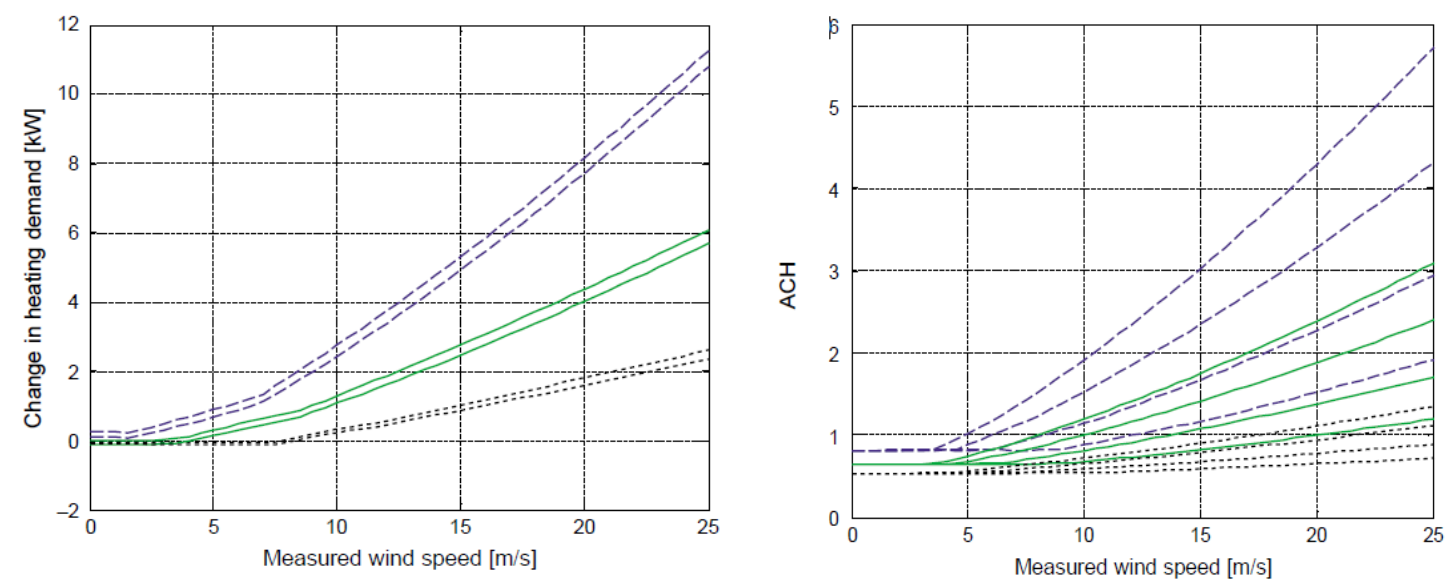

Figure 2.2 (c): Heating demand vs wind speed with airtightness 1,3,6 with (a) mechanical exhaust only ventilation system (b) mechanical exhaust supply system

\subsection{Insulation and Thermal Barrier}

Carlos J Hilado (1979) developed a method to determine the thermal insulation effectiveness at cryogenic temperatures. The study comprised of fabrication of test specimen which were three feet long aluminum pipes coated with one inch of PUF with 25 millimeters of polyvinyl chloride 
jacket and 6 inches of cellular glass in three layers [17]. Extreme low temperatures were obtained during this study by using liquid nitrogen and solid carbon dioxide (Dry Ice). For the calculations, it was assumed that heat transferred from the surroundings was equal to the heat of vaporization of the coolant which in this case were liquid nitrogen and solid carbon dioxide. The time taken to reach the steady state was 30 to 90 minutes. The results of this study are shown below.

\begin{tabular}{|c|c|c|c|c|c|c|c|}
\hline \multirow{2}{*}{\multicolumn{2}{|c|}{$\begin{array}{c}\text { PIPE } \\
\text { TEMPERATURE }\end{array}$}} & \multirow{3}{*}{ THERMAL INSULATION SYSTEM } & \multicolumn{5}{|c|}{ HEAT TRANSFER RATE } \\
\hline & & & \multicolumn{4}{|c|}{ BTU PER HOUR } & \multirow{2}{*}{$\begin{array}{l}\text { BTU PER HOUR } \\
\text { PER FOOT OF PIPE }\end{array}$} \\
\hline${ }^{\circ} \mathrm{C}$. & ${ }^{\circ} \mathbf{F}$. & & 1 & 2 & 3 & AVERAGE & \\
\hline-196 & -320 & $\begin{array}{l}1 \text { inch cellular urethane A, PVC } \\
1 \text { inch cellular urethane B, PVC } \\
4 \text { inches cellutar giass, mastic } \\
6 \text { inches cellular giass, mastic }\end{array}$ & $\begin{array}{l}144.5 \\
153.0 \\
258.5 \\
208.5\end{array}$ & $\begin{array}{l}137.0 \\
153.0 \\
-\overline{198.5}\end{array}$ & $\begin{array}{l}\overline{154.0} \\
- \\
-\end{array}$ & $\begin{array}{l}140.8 \\
153.3 \\
258.5 \\
203.5\end{array}$ & $\begin{array}{l}46.9 \\
51.1 \\
86.2 \\
67.8\end{array}$ \\
\hline-78 & -109 & $\begin{array}{l}1 \text { inch cellular urethane A, PVC } \\
1 \text { inch celtular urethane B, PVC } \\
4 \text { inches cellular glass, mastic } \\
6 \text { inches cellular glass, mastic }\end{array}$ & $\begin{array}{r}68.0 \\
71.1 \\
107.0 \\
105.0\end{array}$ & $\begin{array}{l}69.0 \\
69.0 \\
- \\
-\end{array}$ & $\begin{array}{l}- \\
- \\
-\end{array}$ & $\begin{array}{r}68.5 \\
70.0 \\
107.0 \\
105.0\end{array}$ & $\begin{array}{l}22.8 \\
23.4 \\
35.6 \\
35.0\end{array}$ \\
\hline
\end{tabular}

Figure 2.3 (a): Heat Flow through Various Thermal Insulation Systems

The results clearly show that the heat flow behavior for pipe insulation is very much different from heat flow behavior for insulation on flat surfaces. The results of the experiment indicated that $75 \%$ of heat flow was permitted at $-320^{\circ} \mathrm{F}$ and $65 \%$ heat flow was permitted at $-109^{\circ} \mathrm{F}$. In both cases the thermal insulation material was polyurethane foam (PUF) with 6 inches of cellular glass. The results of this experiment also indicate that low conductivity materials are better for small diameter pipes. The 2:1 to 3:1 advantage of polyurethane foam over cellulose glass on flat surfaces becomes 4:1 to 6:1 advantage on 3 inches nominal diameter pipe [17]. The estimated error for this study was estimated to be $5 \%$.

Further, a thesis done by Somayeh Asadi at Louisiana State University on "Thermal Performance and Cost Effectiveness of Radiant Barrier Thermal Insulation Materials in Residential Construction" involved the installation of thermocouples, data loggers and wireless Vantage Pro was installed in both houses for eight months [18]. 


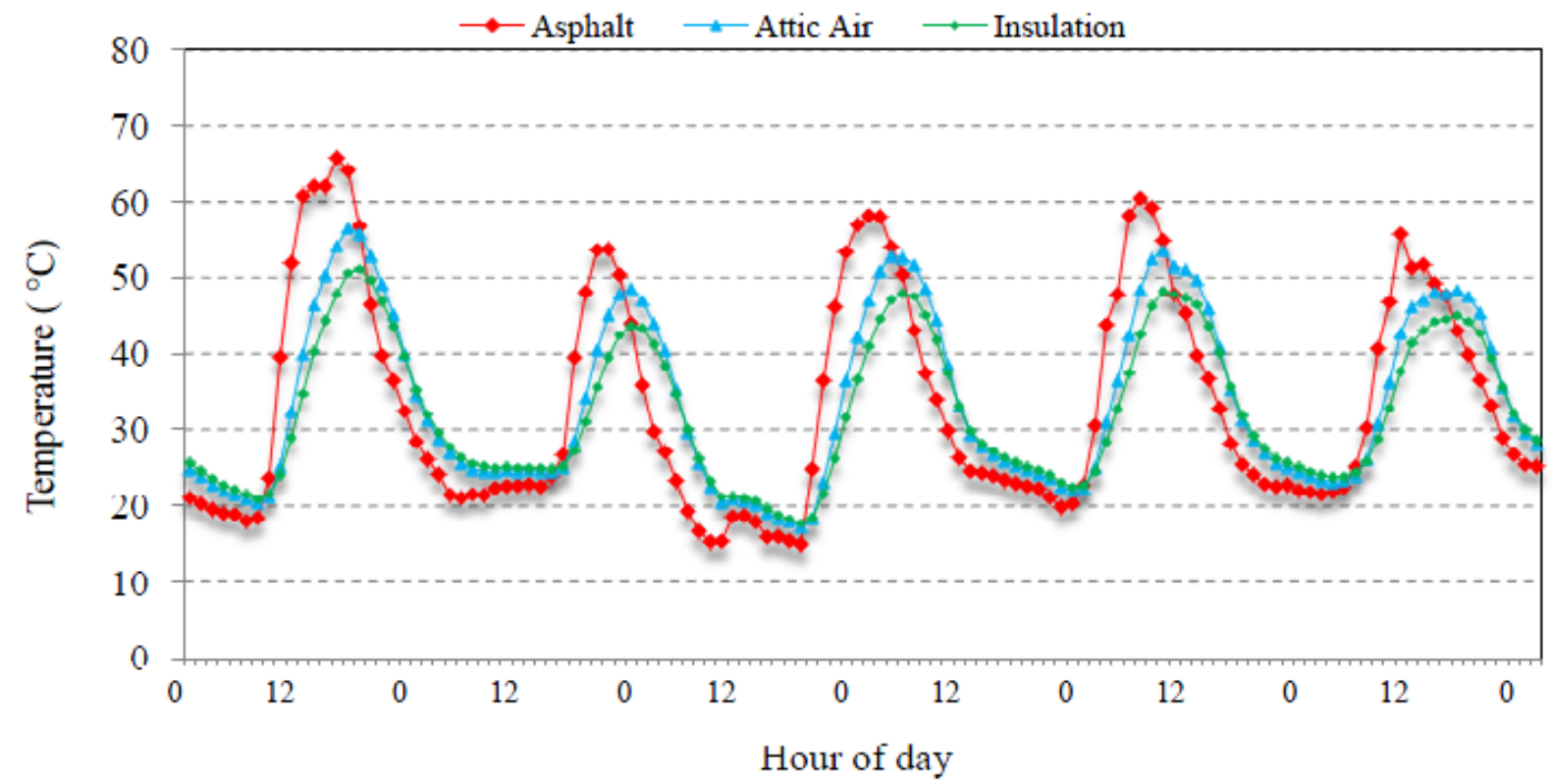

Figure 2.3 (b): Various Temperatures in the House without Radiant Barrier in Summer

The results of this study show that there was a difference of $6^{\circ} \mathrm{C}$ in the attic air temperature with radiant barrier. Also, it was noticed that due to low emissivity and absorptivity, there was a decrease in infrared radiation on the attic floor. The results of this study also indicate that heating loads can be decreased by $11 \%$ by using radiant energy barrier depending on the climatic zone.

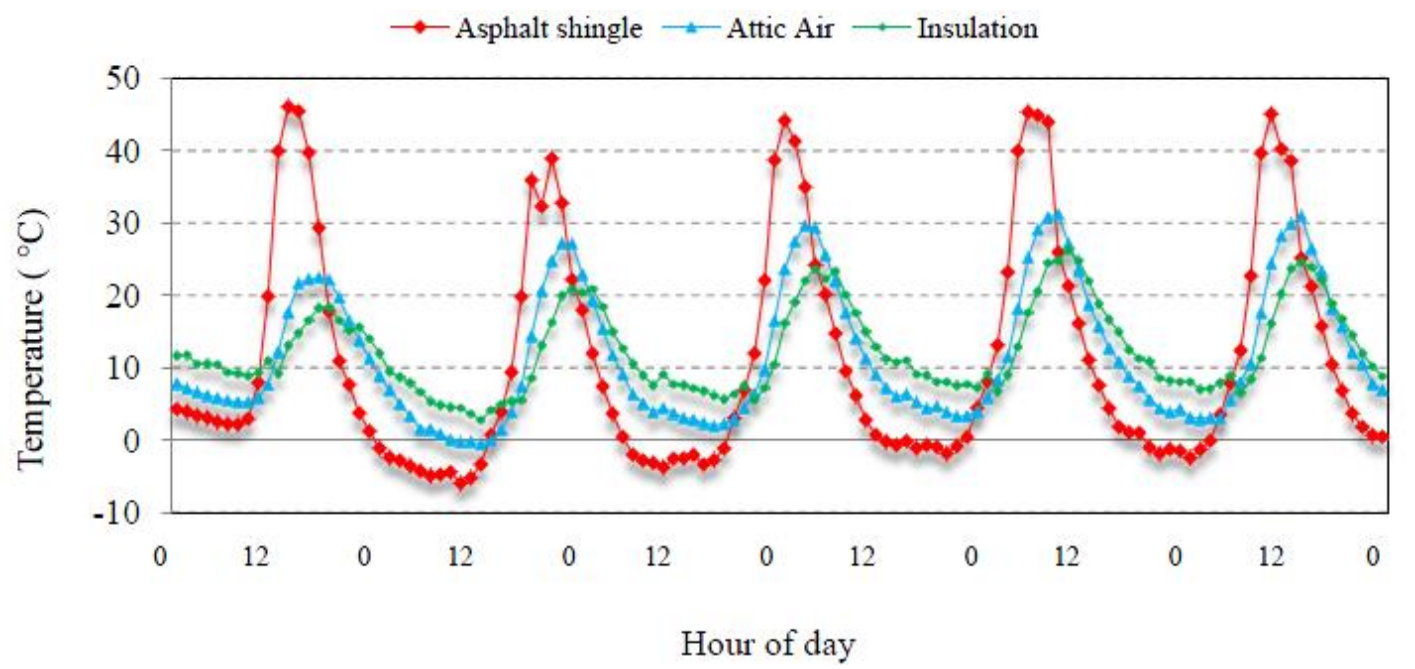

Figure 2.3 (c): Various Temperatures in the House with Radiant Barrier in Summer 
A 3-D transient model was developed to calculate the temperature distribution in different parts of the house. This modeling was done using the ABAQUS 6.9 software. The results of the finite element analysis are shown in Figure 2.3 (d)

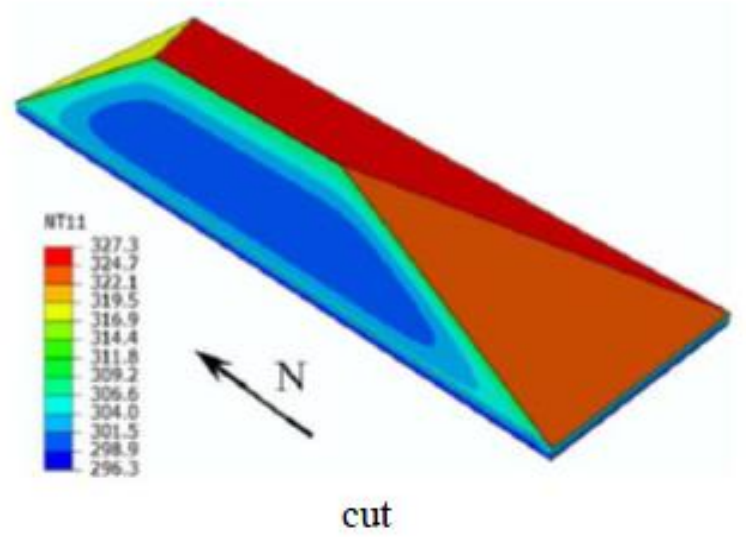

(a)

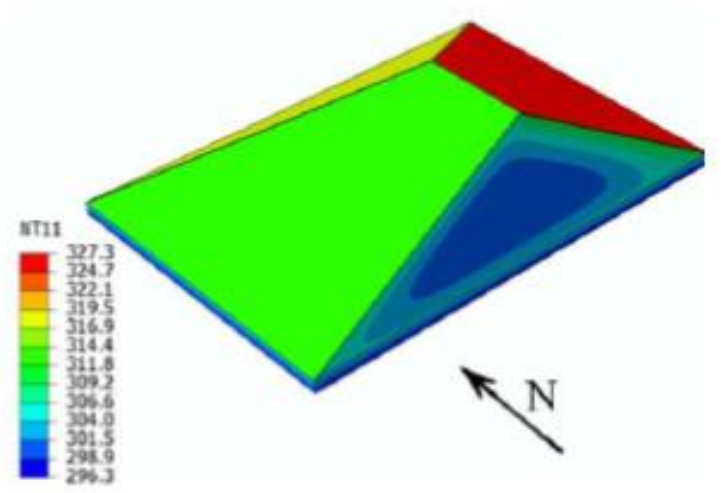

(b)

Figure 2.3 (d): Contour of Temperature Distribution (a) XY plane (b) YZ plane

The results of the FE study clearly indicated that there was a $21 \%$ reduction in heat flux by using radiant barrier systems. This reduction in heat flux reduced the cooling load in the houses by 18 percent.

\subsection{Effect on Energy Consumption}

Amery and Kippenhan monitored the energy consumption of single family houses for 15 years. Two of the houses were constructed according to the existing standards at the time of construction and two houses were constructed with improved thermal resistance. There was a significant difference in the lifestyle of all the four families. But the author concluded that the space energy heating behavior remained remarkably constant. It was observed that even though there was wear and tear in the houses over the years but the energy consumption of the houses almost remained the same. [19] 


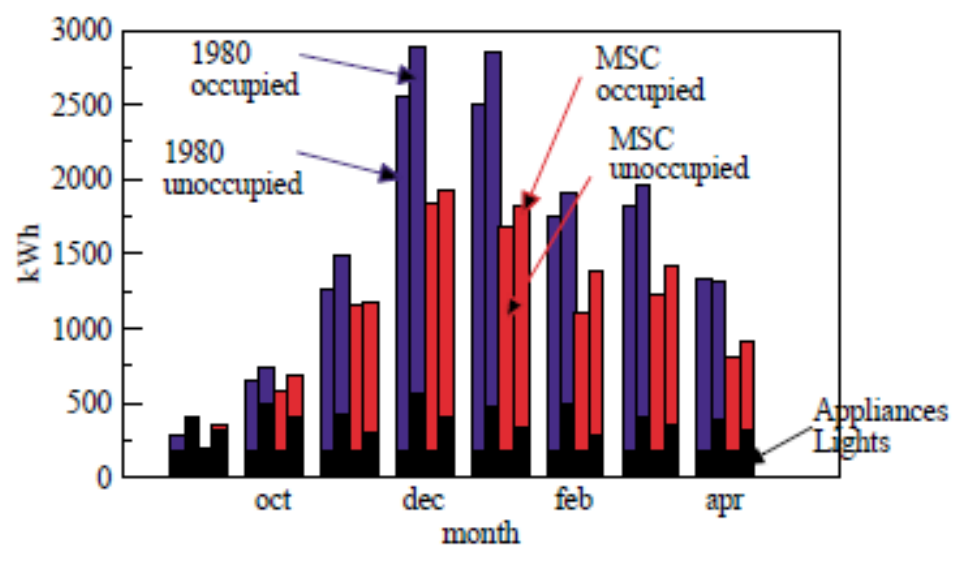

\section{Figure 2.4 (a): The Effect of Occupants on Energy Usage for 1987-1988 Heating Season}

The MSC house had a heat recovery system. The energy required to heat the outside air in the occupied 1980 house was almost double than heating the unoccupied house (29\% as compared to 14\%). On the other hand, for the Model Conservation Standard (MCS) house with forced infiltration the energy required to heat the unoccupied house was more than occupied house (40\% as compared to $29 \%$ ).

An experimental study was done in Thailand to assess the behavior of different thicknesses of insulation on air conditioning loads, when placed on inside and outside portions of the wall. The data was collected from data loggers and thermocouples and a small weather station in the nearby area. The experimental and simulated values of heat flux, solar radiation and cooling coil loads were compared and the simulation software used was BESim. The experiment room was assumed to serve consecutively three residential functions of bedroom (BR), living room (LR) and studio room (STR). This paper concluded that when there is no window on the wall, an insulation placed on the interior will improve wall performance and will be cost effective (Life Cycle Cost analysis). On the other hand, insulation placed on the exposed of the wall increases the heat transfer and thus increasing the temperature [20]. 


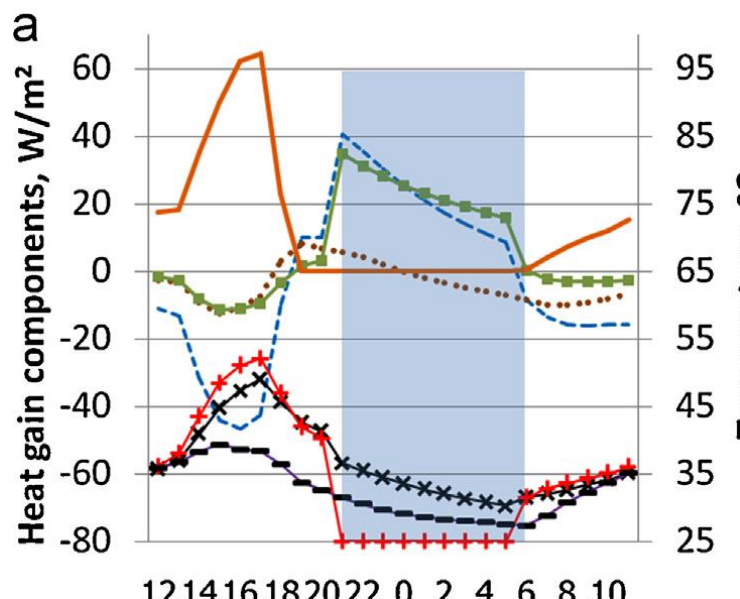

Time, hour

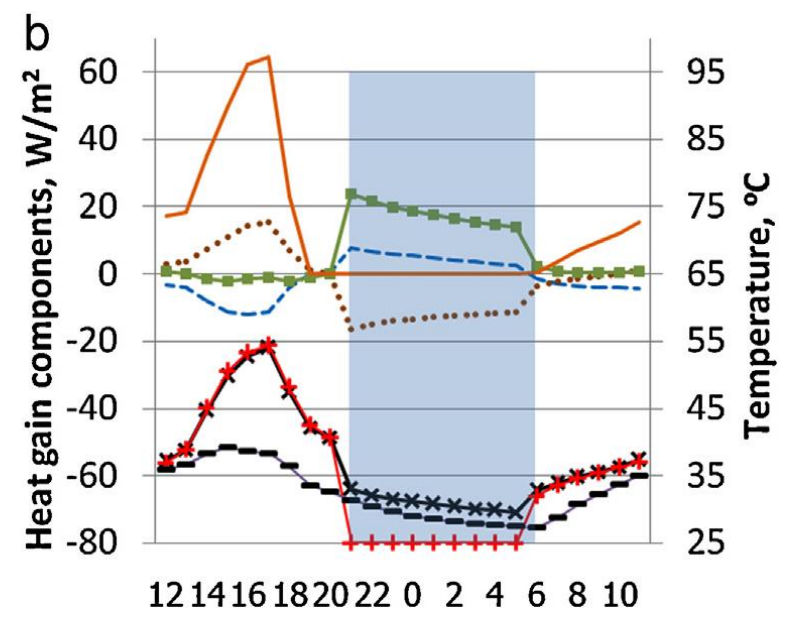

Time, hour

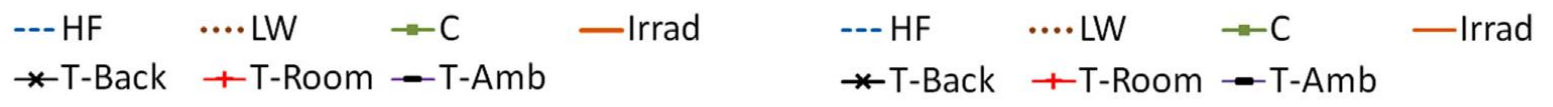

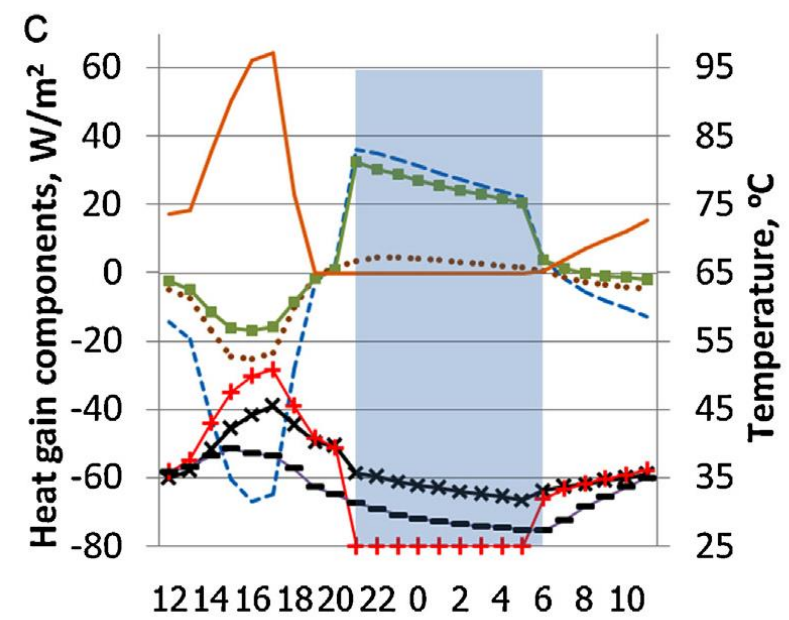

Time, hour

$$
\begin{array}{lll}
---\mathrm{HF} & \cdots \cdot \mathrm{LW} \quad-\mathrm{L} \quad \text { - Irrad } \\
* \text {-T-Back } & + \text { T-Room } & - \text { T-Amb }
\end{array}
$$

Figure 2.4 (b): Temperature and Heat Gain Components of the exposed wall: (a) No

\section{insulation, (b) Interior Insulated, (c) Exterior Insulated}

Yao and Steemers presented a Simple Method of Formulating Load Profile (SMLP) in 2004 for UK buildings. A thermal resistant network method was used to create load profile for domestic space heating for different houses. This method can predict the daily usage profile for heating, hot water demand and appliances. The paper makes use of the data provided by www.statistics.gov.uk about the energy consumption for space heating, water heating, appliances and composition of household in recent years. The heating load profile depends on air 
temperature, orientation of the building, local climate, etc. The paper validates the SMLP by profiling 100 households and load trends of national data. The $R^{2}$ value obtained in this comparison was 0.8425 which indicates that the co-relation is significant and the method is applicable [21].

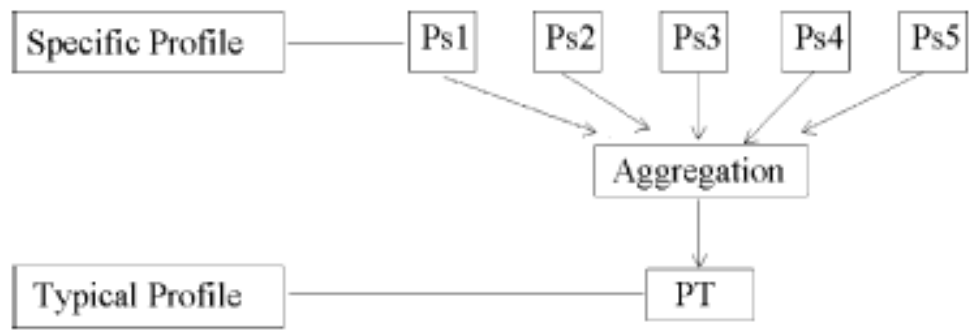

Figure 2.4 (c): Framework of Generating Typical Heating Load Profile
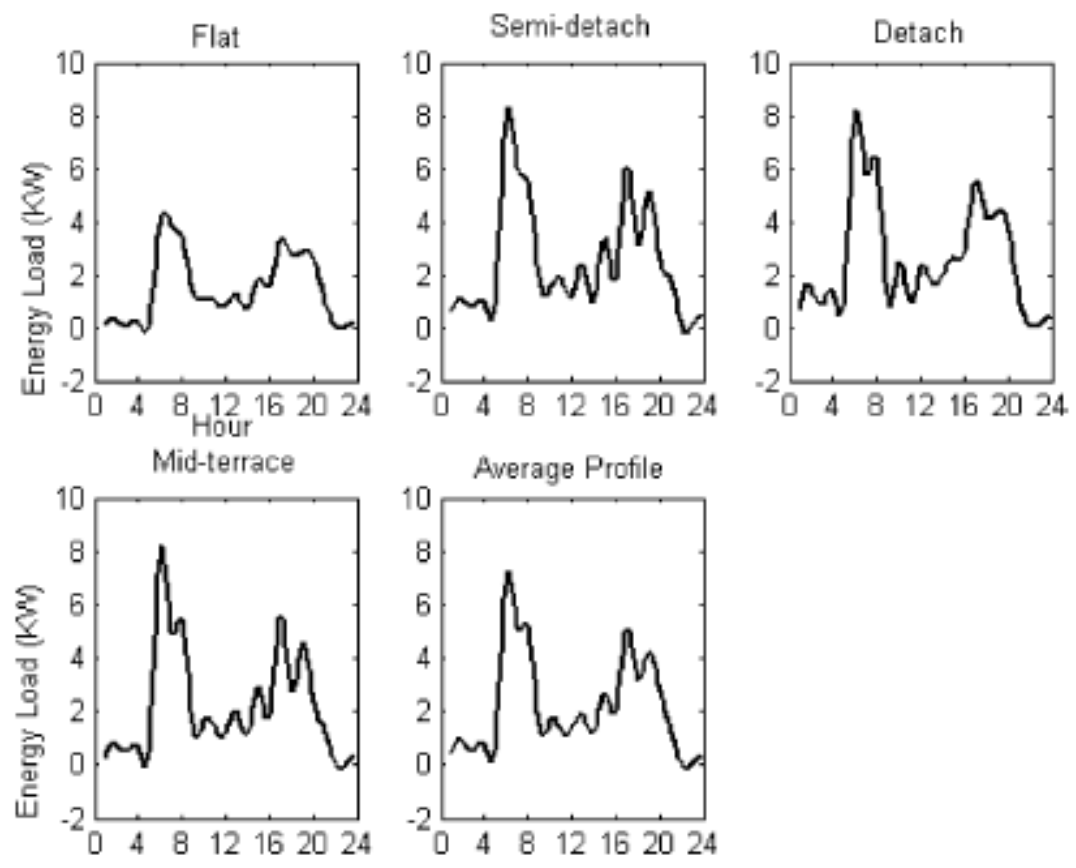

Figure 2.4 (d): Typical Heating Load Profile of a Dwelling

\subsection{Empirical Modeling}

Carlo and Lamberts developed a regression equation using 5000 alternatives to predict an electricity consumption indicator which had the variables like wall to window ratio, solar heat gain coefficient, solar protection angles, building volume indicators, and the roof $\mathrm{U}$ value. 


$$
\begin{aligned}
\mathrm{EC}= & -175.30\left(\frac{A_{\mathrm{p}}}{A_{\text {tot }}}\right)-212.79\left(\frac{A_{\text {env }}}{V_{\text {tot }}}\right)+21.86 \mathrm{WWR} \\
& +5.59 \mathrm{SHGC}-0.19 \mathrm{VSA}+0.15 \mathrm{HSA}+2.34 U_{\text {roof }} \\
& +0.19 \mathrm{ILD} \cdot \mathrm{Sch}\left(\frac{A_{\text {proof }}}{A_{\text {tot }}}\right)\left(\frac{A_{\text {env }}}{V_{\text {tot }}}\right) \\
& +213.35\left(\frac{A_{\text {proof }}}{A_{\text {tot }}}\right)\left(\frac{A_{\text {env }}}{V_{\text {tot }}}\right)-0.04 \mathrm{WWR} \cdot \mathrm{SHGC} \cdot \mathrm{VSA} \\
& -0.45 \mathrm{WWR} \cdot \mathrm{HSA} \quad\left(A_{\text {proof }}<500 \mathrm{~m}^{2}\right) \\
\mathrm{EC}= & -14.14\left(\frac{A_{\mathrm{p}}}{A_{\text {tot }}}\right)-113.94\left(\frac{A_{\text {env }}}{V_{\text {tot }}}\right)+50.82 \mathrm{WWR} \\
& +4.86 \mathrm{SHGC}-0.32 \mathrm{VSA}+0.26 \mathrm{HSA}+1.76 U_{\text {roof }} \\
& -0.13 \mathrm{ILD} \cdot \mathrm{Sch}\left(\frac{V_{\text {tot }}}{A_{\text {env }}}\right)-0.54 \mathrm{WWR} \cdot \mathrm{HSA}+0.92 \mathrm{ILD} \\
& +1.74 \mathrm{Sch}+0.81 \mathrm{ILD} \cdot \mathrm{Sch} \quad\left(A_{\text {proof }}>500 \mathrm{~m}^{2}\right)
\end{aligned}
$$

where $A_{\text {proof }}$ is the area of the horizontal projection of the building $\left(\mathrm{m}^{2}\right) ; A_{\mathrm{tot}}$ is the total floor area $\left(\mathrm{m}^{2}\right) ; A_{\text {env }}$ is the envelope area $\left(\mathrm{m}^{2}\right) ;$ $V_{\text {tot }}$ is the building volume $\left(\mathrm{m}^{3}\right)$; WWR is the window to wall ratio; VSA is the vertical shading angle $\left({ }^{\circ}\right)$; HSA is the horizontal shading angle $\left({ }^{\circ}\right)$; Sch is the lighting, equipment and occupation schedule (h); ILD is the internal load density $\left(\mathrm{W} / \mathrm{m}^{2}\right)$.

The limitations of this model include the exclusion of $U_{\text {value }}$ of walls, defined shape factor range and inapplicability on large buildings and small or tall buildings. [22]

Wojdyga (2008) assessed the effect of various weather conditions on heat demand in district heating systems. The article concluded that the influence of wind on heat power demand is lower than the influence of solar radiation. It was also concluded that even a small amount of heat loss through walls in energy efficient buildings with low heat transfer coefficient walls, it is surpluses of solar radiation through these walls that can affect the work conditions of central heating systems. [23] 


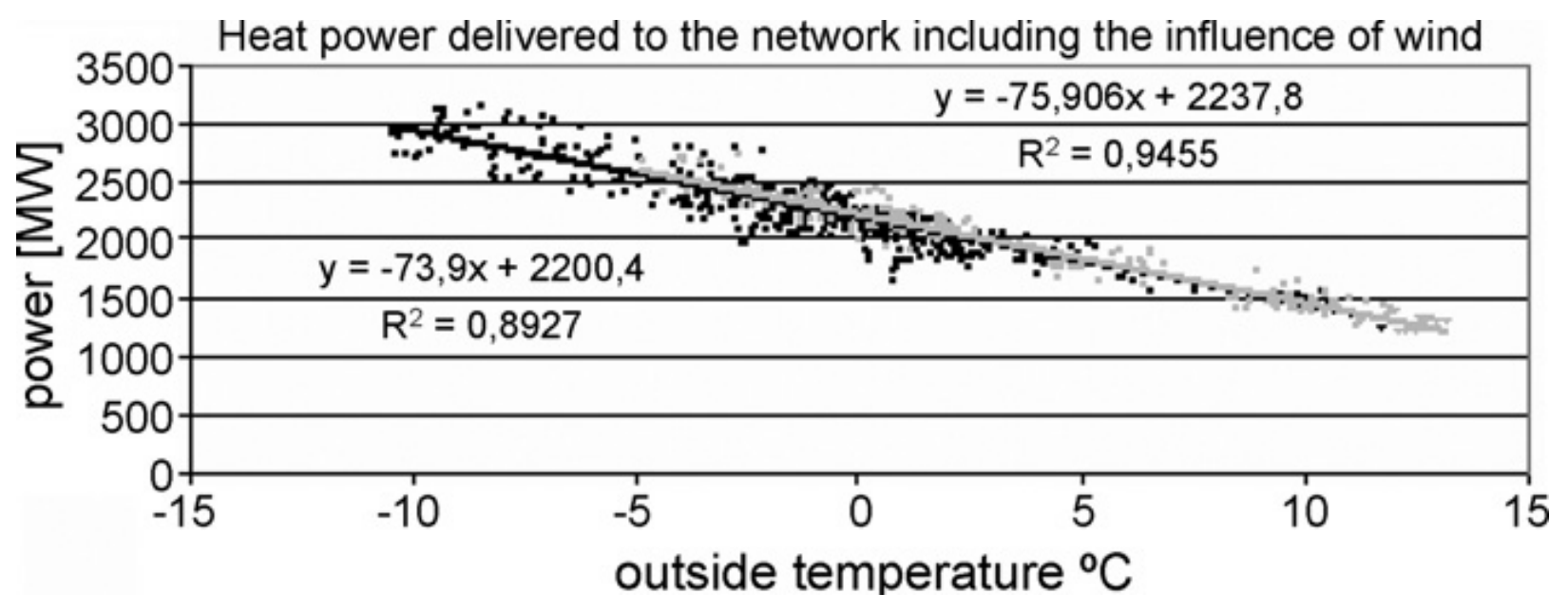

Figure 2.5 (a): Diagram of delivered heat power in the function of outside temperature (dark line) and a similar diagram only for hours with wind stronger than $6 \mathrm{~m} / \mathrm{s}$

Chung and Hui benchmarked the energy efficiency of private buildings in Hong Kong in 2002 by dividing them into three grades, $\mathrm{A}, \mathrm{B}$ and $\mathrm{C}$ based on the quality of the facility. After performing multiple linear regressions between EUI (Energy Use Intensities) and factors like operating hours, it was concluded that grade A buildings should focus on lighting control, office equipment and water side distribution. Grade A/B buildings should focus on water side distribution control and chiller equipment and grade $\mathrm{C}$ buildings should focus on lighting equipment, chillers and office equipment. [25]

\begin{tabular}{|c|c|c|c|c|c|c|}
\hline & \multirow[b]{2}{*}{$\mathrm{R}$-square } & \multicolumn{2}{|l|}{ Grade $A / B$} & \multicolumn{2}{|l|}{ Grade C } & \multirow{2}{*}{$\begin{array}{l}\text { Grade A } \\
0.7387\end{array}$} \\
\hline & & 0.3710 & 0.3628 & 0.5082 & 0.4669 & \\
\hline Factpr Type & Significant factors & $\mathrm{A} 1(\mathrm{CS} / \mathrm{AC})$ & $A 2$ (Tenant/AC) & $\mathrm{A} 3(\mathrm{CS} / \mathrm{no} \mathrm{AC})$ & A4 (Tenant/no AC) & A5 (Whole) \\
\hline People & $\begin{array}{l}\text { Occupants behaviour and Maintenance factor } \\
\text { Indoor temperature set point }\end{array}$ & $\begin{array}{l}\text { NS } \\
\text { NS }\end{array}$ & $\begin{array}{l}-54.3(26.7) \\
\text { NS }\end{array}$ & $\begin{array}{l}\text { NS } \\
-43.9^{*}(13.4)\end{array}$ & $\begin{array}{l}-47.6^{\circ}(41.2) \\
\text { NS }\end{array}$ & $\begin{array}{l}\text { NS } \\
\text { NS }\end{array}$ \\
\hline Energy end-use & 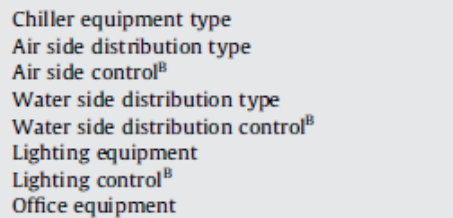 & $\begin{array}{l}-122.8(63.1) \\
\text { NS } \\
\text { NS } \\
\text { NS } \\
-205.0^{\circ}(67.703) \\
\text { NS } \\
\text { NA } \\
\text { NA }\end{array}$ & $\begin{array}{l}\text { NA } \\
\text { NS } \\
\text { NS } \\
\text { NA } \\
\text { NA } \\
\text { NS } \\
\text { NS } \\
67.7^{\circ}(26.7)\end{array}$ & $\begin{array}{l}52.6^{*},{ }^{\mathrm{B}}(17.5) \\
\text { NS } \\
\text { NS } \\
\text { NA } \\
\text { NA } \\
-18.1(8.9) \\
\text { NS } \\
\text { NS }\end{array}$ & $\begin{array}{l}\text { NS } \\
\text { NS } \\
\text { NS } \\
\text { NA } \\
\text { NA } \\
-100.4^{*}(35.8) \\
\text { NS } \\
137.6^{\circ}(39.6)\end{array}$ & $\begin{array}{l}\text { NS } \\
\text { NS } \\
-385.0^{\circ}(140.5) \\
\text { NS } \\
\text { NS } \\
\text { NS } \\
-292.0^{\circ}(103.9) \\
532.9^{\circ}(204.9)\end{array}$ \\
\hline
\end{tabular}

NS = not significant in the stepwise multiple regression model; NA = not applicable; B = binary measure; the value in parenthesis $($ ) =standard error. Significant at the $5 \%$ level.

Figure 2.5 (b): Regression Result of Each User Group 


\section{Chapter 3}

\section{METHODOLOGY}

This chapter discusses the comprehensive testing methodology developed to determine the effect of different factors on heat loss in various houses which are selected as specimen in the experiment.

\subsection{Introduction}

The experiment comprised of collecting data from 20 different small independent houses. The heating system in the houses try to maintain the set point temperature on the thermostat. The amount of heat put in the system or the work done by the heating furnace/heat pump is determined by the variable factors inside and outside the house which are explained in chapter 1. The experiment is designed in such a manner that it covers the effect of all the significant variables which can be fitted in the empirical model. The calculations are done based on ASHRAE 90.2 codes and the data is collected through HOBO data loggers.

\subsection{Data Collected}

The data collected for the experimented is as follows:

\subsubsection{Temperature in the Houses:}

The equipment used in this experiment to get the temperature inside the house was a HOBO data logger for recording temperature and relative humidity measurements at constant intervals for a specified period.

The HOBO U12 Temperature/Relative Humidity/Light/External Data Logger is a four-channel logger with 12-bit resolution and can record up to 43,000 measurements or events. The external channel accepts a variety of sensors, including temperature, and split-core AC current sensors as well as 4-20 mA and voltage input cables. The logger uses a direct USB interface for launching and data readout by a computer. 


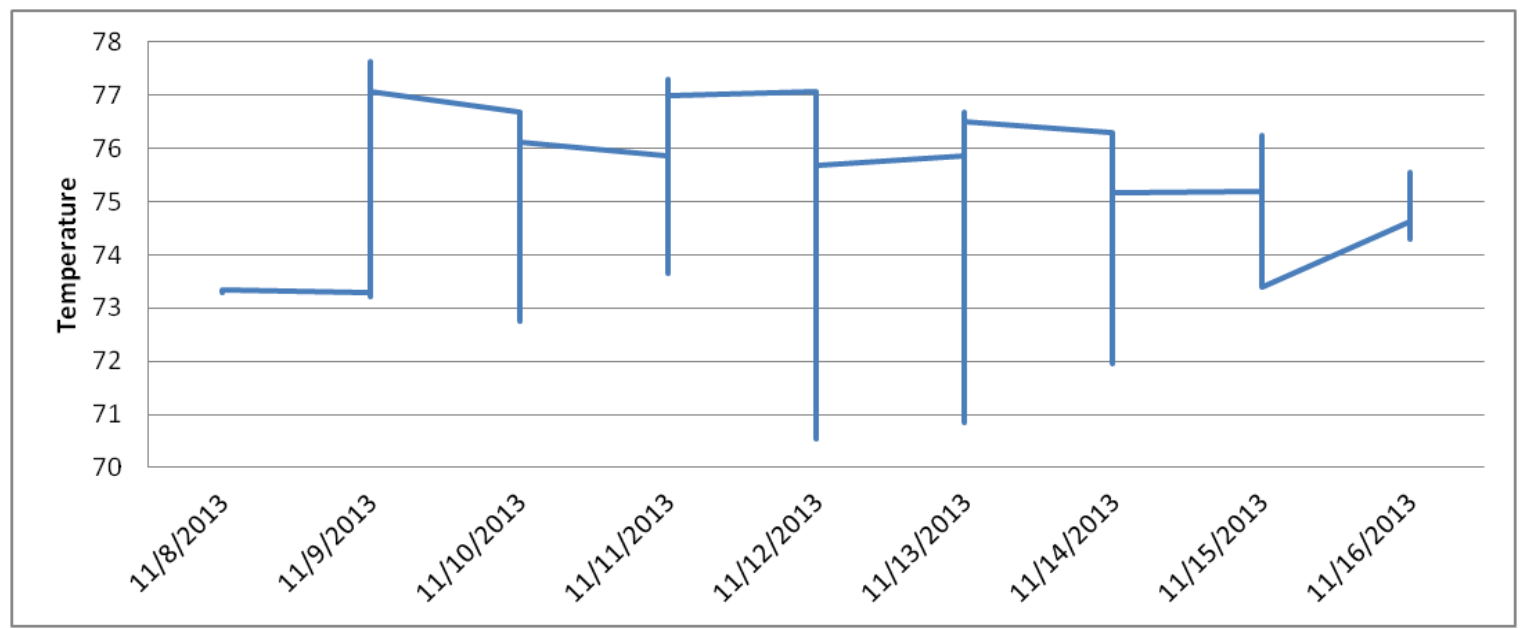

Figure 3.2.1 (a) Hourly Temperature Data in Building 775, Apt 1

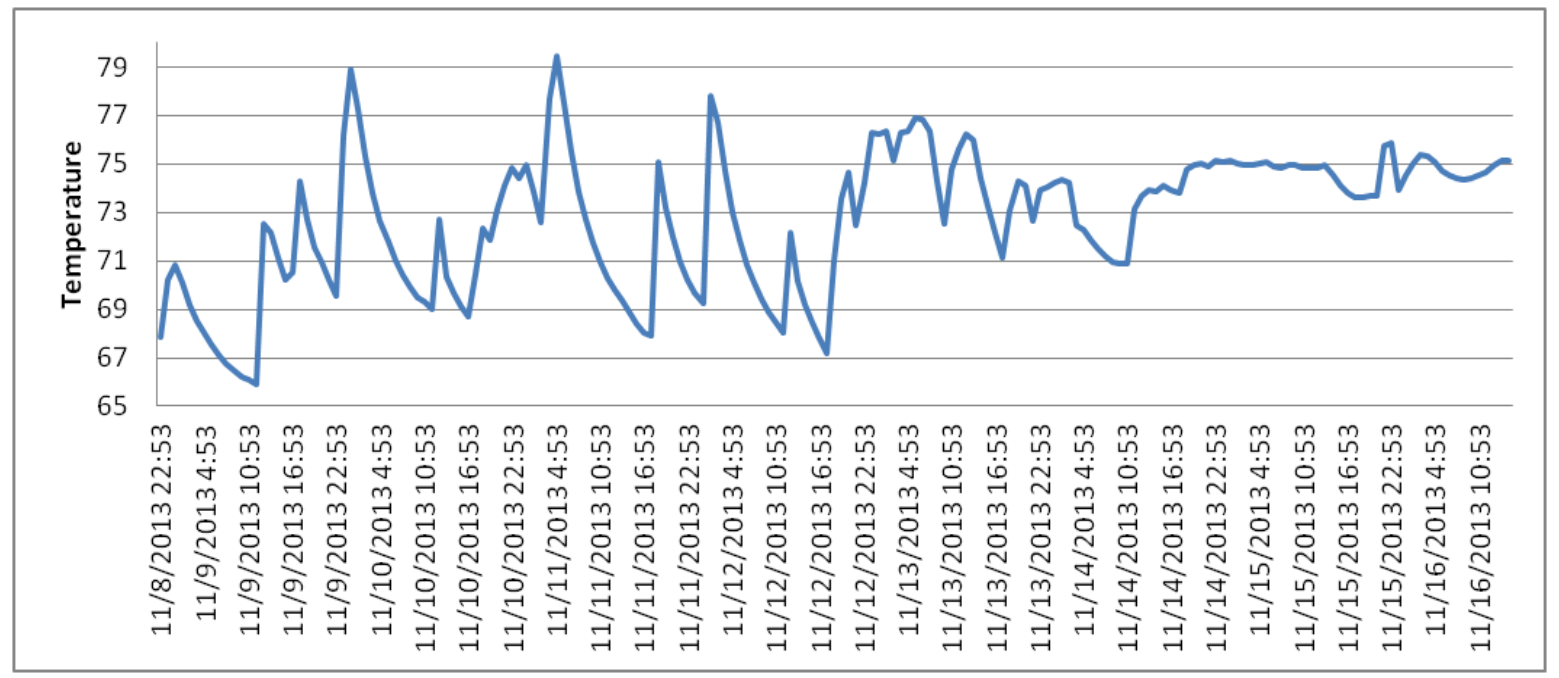

Figure 3.2.1 (b) Hourly Temperature Data in Building 777, Apt 2

An interval of 30 seconds is initialized in the loggers, which means that a temperature value will be recorded inside the house every 30 seconds. These data loggers are kept somewhere near thermostat in the house. 


\subsubsection{Weather Data}

The weather data for empirical modeling which includes the hourly point temperature, wind speed, precipitation and weather conditions, was requested and successfully received from National Climatic Data Center. NOAA's (National Oceanic and Atmospheric Administration) 
National Climatic Data Center is responsible for preserving, monitoring, assessing and providing public access to the Nation's treasure of climate and historical weather data

\begin{tabular}{|c|c|c|c|c|c|c|c|c|c|c|c|c|c|c|c|c|c|c|c|c|c|c|}
\hline \multirow[t]{2}{*}{ Date } & \multirow[t]{2}{*}{$\begin{array}{l}\text { Time } \\
\text { (LST) }\end{array}$} & \multirow[t]{2}{*}{$\begin{array}{c}\text { Station } \\
\text { Type }\end{array}$} & \multirow[t]{2}{*}{$\begin{array}{c}\text { Sky } \\
\text { Conditions }\end{array}$} & \multirow[t]{2}{*}{$\begin{array}{c}\text { Visibility } \\
\text { (SM) }\end{array}$} & \multirow[t]{2}{*}{$\begin{array}{c}\text { Westher } \\
\text { Type }\end{array}$} & \multicolumn{2}{|r|}{$\begin{array}{c}\text { Dry } \\
\text { Bulb } \\
\text { Temp }\end{array}$} & \multicolumn{2}{|c|}{$\begin{array}{l}\text { Wet } \\
\text { Bulb } \\
\text { Temp }\end{array}$} & \multicolumn{2}{|c|}{$\begin{array}{l}\text { Dew } \\
\text { Point } \\
\text { Temp }\end{array}$} & \multirow[t]{2}{*}{$\begin{array}{c}\text { Rel } \\
\text { Humd } \\
\%\end{array}$} & \multirow[t]{2}{*}{$\begin{array}{l}\text { Wind } \\
\text { Speed } \\
(\mathrm{MPH})\end{array}$} & \multirow[t]{2}{*}{$\begin{array}{c}\text { Wind } \\
\text { Dir }\end{array}$} & \multirow[t]{2}{*}{$\begin{array}{l}\text { Wind } \\
\text { Gusts } \\
\text { (MPH) }\end{array}$} & \multirow[t]{2}{*}{$\begin{array}{c}\text { Station } \\
\text { Pressure } \\
\text { (in. hg) }\end{array}$} & \multirow[t]{2}{*}{$\begin{array}{l}\text { Press } \\
\text { Tend }\end{array}$} & \multirow{2}{*}{$\begin{array}{l}\text { Net } \\
3-\text { hr } \\
\text { Chg } \\
\text { (mb) }\end{array}$} & \multirow{2}{*}{$\begin{array}{c}\text { Ses } \\
\text { Level } \\
\text { Pressure } \\
\text { (in. hg) }\end{array}$} & \multirow[t]{2}{*}{$\begin{array}{l}\text { Report } \\
\text { Type }\end{array}$} & \multirow[t]{2}{*}{$\begin{array}{c}\text { Precip. } \\
\text { Total } \\
\text { (in) }\end{array}$} & \multirow[t]{2}{*}{$\begin{array}{l}\text { Alti- } \\
\text { meter } \\
\text { (in. hg }\end{array}$} \\
\hline & & & & & & (F) & (C) & (F) & (C) & $(F)$ & (C) & & & & & & & & & & & \\
\hline 1 & 2 & 3 & 4 & 5 & 6 & 7 & 8 & 9 & 10 & 11 & 12 & 13 & 14 & 15 & 16 & 17 & 18 & 19 & 20 & 21 & 22 & 23 \\
\hline 01 & 0053 & 12 & ovc021 & 10.00 & & 35 & 1.7 & 31 & -0.4 & 25 & -3.9 & 87 & 7 & 220 & & 28.69 & & & 30.06 & AA & & 30.03 \\
\hline 01 & 0153 & 12 & EKNO25 OVC029 & 9.00 & & 35 & 1.7 & 32 & -0.2 & 28 & -3.3 & 70 & 7 & 220 & & 28.69 & & & 30.05 & AA & & 30.02 \\
\hline 01 & 0212 & 12 & ovc025 & 2.50 & $-\mathrm{SN}$ & 34 & 1.0 & 32 & -0.1 & 28 & -2.0 & 79 & 8 & 220 & & 28.69 & & & M & SP & & 30.03 \\
\hline 01 & 0221 & 12 & ovc023 & 3.00 & $-\mathrm{SN}$ & 34 & 1.0 & 32 & -0.1 & 28 & -2.0 & 79 & 7 & 210 & & 28.69 & & & M & SP & & 30.03 \\
\hline 01 & 0251 & 12 & SCT019 OVCO25 & 2.50 & -SN BR & 34 & 1.0 & 32 & -0.1 & 28 & -2.0 & 79 & 5 & 210 & & 28.70 & & & m & SP & & 30.04 \\
\hline 01 & 0253 & 12 & FEW012 SCT017 OVC025 & 2.00 & -SN BR & 33 & 0.6 & 31 & -0.3 & 29 & -1.7 & 85 & 3 & 210 & & 28.70 & & & 30.07 & AA & T & 30.04 \\
\hline 01 & 0256 & 12 & FEW009 SCT017 OVC025 & 1.75 & -SN BR & 32 & 0.0 & 30 & -0.8 & 28 & -2.0 & 85 & 5 & 200 & & 28.69 & & & M & SP & & 30.03 \\
\hline 01 & 0320 & 12 & BKNO09 EKNO17 OVC027 & 2.50 & $-S N$ BR & 32 & 0.0 & 31 & -0.4 & 30 & -1.0 & 92 & 5 & 210 & & 28.69 & & & M & $\mathrm{SP}$ & & 30.03 \\
\hline 01 & 0323 & 12 & SCT007 BKN011 OVC027 & 3.00 & $-S N B R$ & 32 & 0.0 & 31 & -0.4 & 30 & -1.0 & 92 & 5 & 210 & & 28.89 & & & M & SP & & 30.03 \\
\hline 01 & 0336 & 12 & EKNO09 OVCO15 & 4.00 & $-S N B R$ & 32 & 0.0 & 31 & -0.4 & 30 & -1.0 & 92 & 8 & 210 & & 28.69 & & & M & SP & & 30.03 \\
\hline 01 & 0353 & 12 & ovco09 & 5.00 & $B R$ & 32 & 0.0 & 31 & -0.4 & 30 & -1.1 & 92 & 5 & 210 & & 28.69 & & & 30.08 & AA & $\mathrm{T}$ & 30.02 \\
\hline 01 & 0410 & 12 & ovco09 & 2.00 & $-S N Q R$ & 32 & 0.0 & 31 & -0.4 & 30 & -1.0 & 92 & 3 & 210 & & 28.69 & & & M & $\mathrm{SP}$ & & 30.02 \\
\hline 01 & 0417 & 12 & EKNOOT OVCO11 & 1.75 & $-S N B R$ & 32 & 0.0 & 31 & -0.4 & 30 & -1.0 & 92 & 3 & 210 & & 28.69 & & & M & SP & & 30.02 \\
\hline 01 & 0453 & 12 & ovc007 & 1.75 & -SN BR & 32 & 0.0 & 31 & -0.4 & 30 & -1.1 & 92 & 8 & 210 & & 28.68 & & & 30.04 & AA & $\mathrm{T}$ & 30.01 \\
\hline 01 & 0505 & 12 & EKN007 OVCO11 & 2.00 & -SN BR & 32 & 0.0 & 31 & -0.4 & 30 & -1.0 & 92 & 5 & 210 & & 28.88 & & & M & SP & & 30.01 \\
\hline 01 & 0527 & 12 & EKN007 OVC011 & 3.00 & BR & 32 & 0.0 & 31 & -0.4 & 30 & -1.0 & 92 & 8 & 200 & & 28.86 & & & m & SP & & 30.00 \\
\hline 01 & 0553 & 12 & EKN007 OVCO11 & 3.00 & BR & 32 & 0.0 & 32 & -0.2 & 31 & -0.8 & 98 & 5 & 200 & & 28.68 & & & 30.03 & AA & $\mathrm{T}$ & 30.00 \\
\hline 01 & 0804 & 12 & ovc007 & 2.50 & BR & 32 & 0.0 & 31 & -0.4 & 30 & -1.0 & 92 & 3 & 210 & & 28.68 & & & M & SP & & 30.00 \\
\hline 01 & 0813 & 12 & EKN007 OVC011 & 3.00 & BR & 32 & 0.0 & 31 & -0.4 & 30 & -1.0 & 92 & 3 & 210 & & 28.68 & & & M & SP & & 30.00 \\
\hline 01 & 0842 & 12 & EKN007 OVCO23 & 2.50 & ER & 32 & 0.0 & 31 & -0.4 & 30 & -1.0 & 92 & 3 & 200 & & 28.68 & & & M & SP & & 30.00 \\
\hline 01 & 0648 & 12 & SCT007 OVC021 & 1.75 & $-S N$ BR & 32 & 0.0 & 31 & -0.4 & 30 & -1.0 & 92 & 5 & 210 & & 28.66 & & & M & $\mathrm{SP}$ & & 30.00 \\
\hline 01 & 0853 & 12 & FEW004 SCT007 OVC019 & 1.50 & $-S N$ BR & 32 & 0.0 & 32 & -0.2 & 31 & -0.6 & 96 & 5 & 210 & & 28.68 & & & 30.03 & AA & $\mathrm{T}$ & 30.00 \\
\hline 01 & 0705 & 12 & EKN004 BKN007 OVC017 & 1.50 & -SN BR & 32 & 0.0 & 31 & -0.4 & 30 & -1.0 & 92 & 3 & 210 & & 28.86 & & & M & SP & & 30.00 \\
\hline 01 & 0721 & 12 & EKNO04 OVCO17 & 2.00 & BR & 32 & 0.0 & 31 & -0.4 & 30 & -1.0 & 92 & 5 & 210 & & 28.88 & & & M & SP & & 30.01 \\
\hline 01 & 0753 & 12 & EKN004 OVCO07 & 2.00 & BR & 32 & 0.0 & 32 & -0.2 & 31 & -0.8 & 98 & 5 & 210 & & 28.86 & & & 30.03 & AA & 0.01 & 30.00 \\
\hline 01 & 0804 & 12 & ovc004 & 1.50 & BR & 32 & 0.0 & 31 & -0.4 & 30 & -1.0 & 92 & 3 & 210 & & 28.88 & & & M & SP & & 30.01 \\
\hline 01 & 0828 & 12 & EKNOOB OVC026 & 2.00 & $B R$ & 32 & 0.0 & 31 & -0.4 & 30 & -1.0 & 92 & 5 & 200 & & 28.68 & & & m & SP & & 30.01 \\
\hline 01 & 0841 & 12 & EKNO04 OVCO09 & 2.00 & BR & 32 & 0.0 & 31 & -0.4 & 30 & -1.0 & 92 & 6 & 200 & & 28.69 & & & M & SP & & 30.02 \\
\hline 01 & 0849 & 12 & EKN004 BKN018 OVCO42 & 3.00 & BR & 32 & 0.0 & 31 & -0.4 & 30 & -1.0 & 92 & 8 & 210 & & 28.69 & & & M & SP & & 30.03 \\
\hline 01 & 0853 & 12 & FEW002 EKN006 OVC048 & 3.00 & ER & 32 & 0.0 & 32 & -0.2 & $31 \mid$ & -0.6 & 98 & 8 & 200 & & 28.69 & & & 30.08 & AA & 0.01 & 30.03 \\
\hline
\end{tabular}

Figure 3.2.2 Hourly Meteorological Data by NCDC 


\subsubsection{Actual Energy Consumption}

The readings from the electric meters were noted down before and after the experiment. The difference of these values was the total electricity or the gas consumption in a particular house. As defined by ASHRAE that $41.5 \%$ of the total energy used in a residential house is used for heating loads in North America, so $41.5 \%$ of the actual consumption in a house (difference of before and after readings) was the energy used for heating during the period of experiment (assumption in the model). Figure 3.2.3 shows the $\mathrm{kWh}$ reading obtained from the electricity meter from one of the houses.

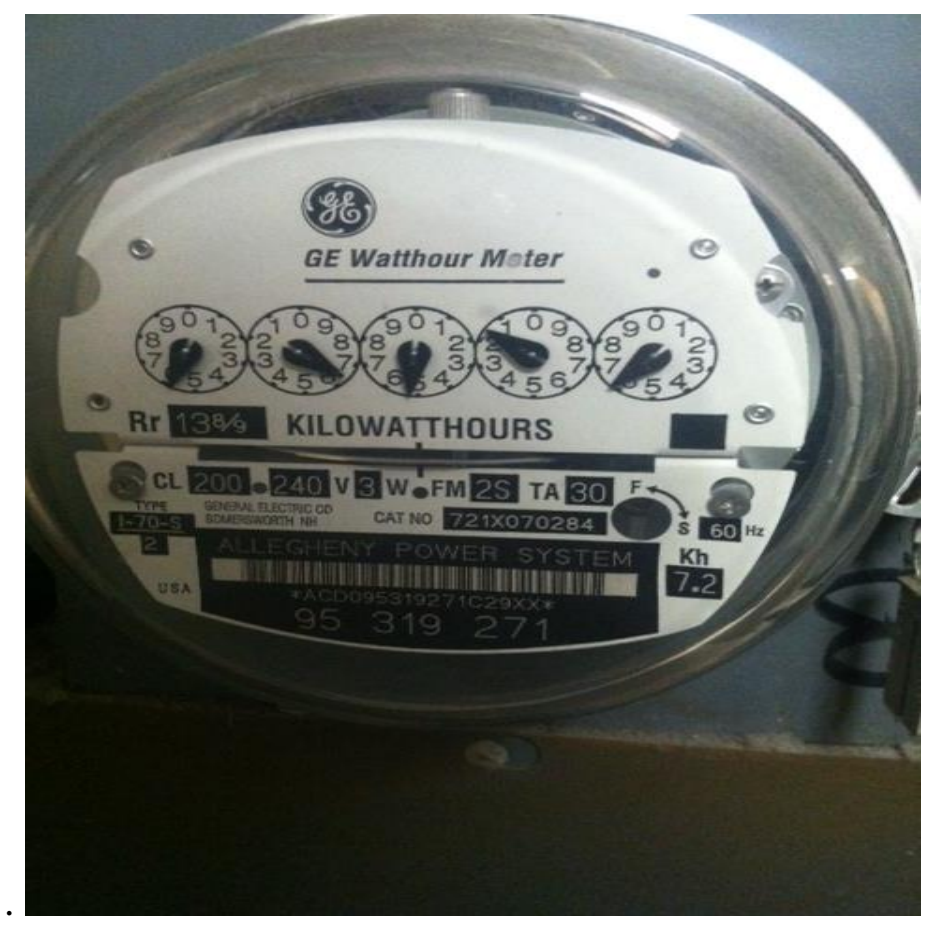

Figure 3.2.3: kWh Reading

\begin{tabular}{|c|c|c|c|}
\hline S. No & Building Name & Apt No & Energy Usage (kWh) \\
\hline 1 & \multirow{4}{*}{ MTW } & 102 & 1,579 \\
\hline 2 & & 201 & 2,000 \\
\hline 3 & & 202 & 1,500 \\
\cline { 4 - 4 } & & 301 & 1,800 \\
\hline 4 & & 302 & 1,720 \\
\hline 5 & & & \\
\hline
\end{tabular}




\begin{tabular}{|c|c|c|c|}
\hline S. No & Building Name & Apt No & Energy Usage (kWh) \\
\hline 6 & \multirow{6}{*}{775} & 1 & 588 \\
\hline 7 & & 3 & 1038 \\
\hline 8 & & 102 & 761 \\
\hline 9 & & 203 & 480 \\
\hline 10 & & 205 & 837 \\
\hline 11 & & 4 & 434 \\
\hline 12 & \multirow{4}{*}{777} & 1 & 938 \\
\hline 13 & & 2 & 445 \\
\hline 14 & & 103 & 845 \\
\hline 15 & & 106 & 590 \\
\hline
\end{tabular}

Table 3.2.3: kWh Usage in Residential Houses

\subsubsection{Blower Door Tests (Leakage Area)}

Blower door tests were done on every floor of all the three buildings. The purpose of all these tests was to find leakage area of the house. The house was depressurized to $-50 \mathrm{~Pa}$ by a fan which has a variable speed drive installed on it. The readings noted down from the experiment was CFM at $50 \mathrm{~Pa}$. The gauge in the blower door test gave the $\mathrm{cfm}$ reading and following equations were used to calculate the leakage at natural conditions.

$$
\begin{aligned}
\text { Natural CFM } & =\frac{\text { CFM50 }}{n} \\
\text { Natural CFM } & =\frac{935}{18.2}
\end{aligned}
$$

Now, to convert cfm to air changes per hour:

$$
\mathrm{ACH}=\frac{\text { Natural CFM } \times 60}{\text { Area } \times \text { Height }}
$$

Where,

$$
\mathrm{n}=\text { Lawrence Berkeley Laboratory }(\mathrm{LBL}) \mathrm{n} \text { factor for ventilation, } 18.2
$$




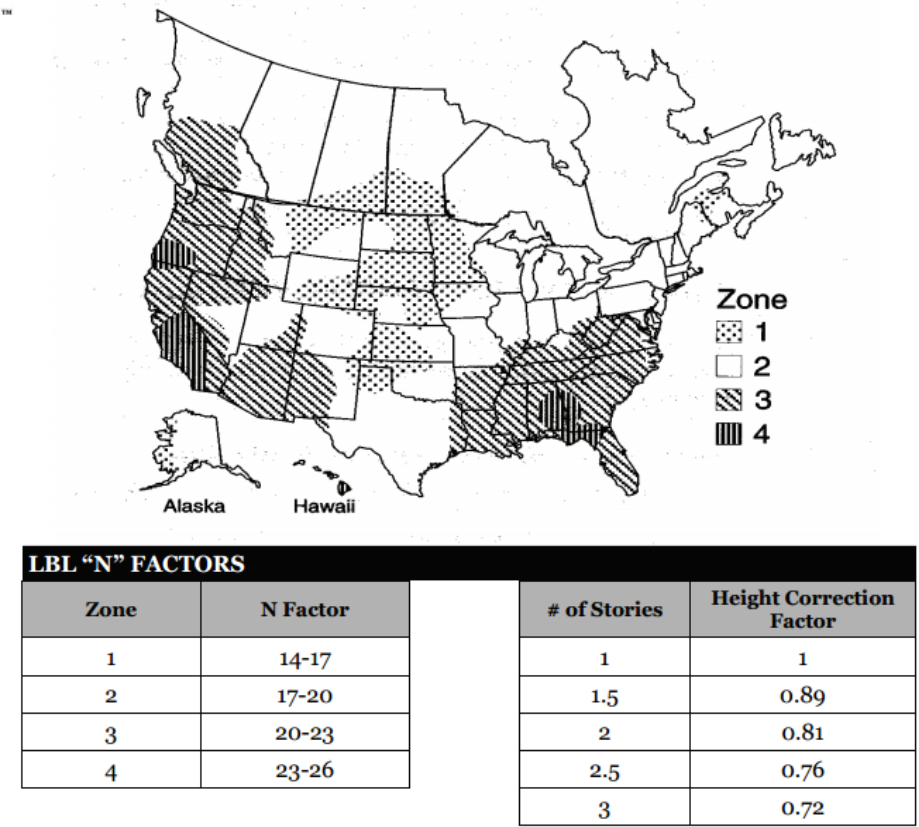

Figure 3.2.4: $\mathrm{LBL} \mathbf{n}$ factor for ventilation

\begin{tabular}{|c|c|c|c|}
\hline S. No & Building Name & Apt No & Air Leakage (at 50 Pa) \\
\hline 1 & \multirow{5}{*}{ MTW } & 102 & 601 \\
\hline 2 & & 201 & 532 \\
\hline 3 & & 202 & 536 \\
\hline 4 & & 301 & 596 \\
\hline 5 & & 302 & 594 \\
\hline 6 & \multirow{6}{*}{775} & 1 & 931 \\
\hline 7 & & 3 & 940 \\
\hline 8 & & 102 & 810 \\
\hline 9 & & 203 & 1,471 \\
\hline 10 & & 205 & 1,420 \\
\hline 11 & & 4 & 950 \\
\hline 12 & \multirow{4}{*}{777} & 1 & 931 \\
\hline 13 & & 2 & 951 \\
\hline 14 & & 103 & 810 \\
\hline 15 & & 106 & 820 \\
\hline
\end{tabular}

Table 3.2.4: Air Leakage in Residential Houses 


\subsection{Use of ASHRAE Equations}

For calculating the values of heat loss by different factors such as wind, infiltrations etc some equations are used from ASHRAE Handbook 2009 and standard values are used in some equations.

\subsubsection{Heat Loss or Ideal Furnace Consumption}

The ideal furnace consumption can be evaluated by calculating the heat loss taking in account the area of the particular house and R and U values specified by IECC 2009 for Monongalia County. Figure 3.5.1 shows the R values and $\mathrm{U}$ values for West Virginia.

\begin{tabular}{|l|c|}
\hline \multicolumn{2}{|c|}{ Climate Zone 5 and 4 Marine } \\
\hline Ceiling R-value & $\mathbf{3 8}$ \\
\hline Wood Frame Wall R-value & $\mathbf{2 0 ~ o r ~ 1 3 + 5 ^ { \mathbf { h } }}$ \\
\hline Mass Wall R-value i & $\mathbf{1 3 / 1 7}$ \\
\hline Floor R-value & $\mathbf{3 0}$ \\
\hline Basement Wall R-value c & $\mathbf{1 0 / 1 3}$ \\
\hline Slab R-value d, Depth & $\mathbf{1 0 , 2} \mathbf{~ f t}$ \\
\hline Crawlspace Wall R-value c & $\mathbf{1 0 / 1 3}$ \\
\hline Fenestration U-Factor b & $\mathbf{0 . 3 5}$ \\
\hline Skylight U-Factor b & $\mathbf{0 . 6}$ \\
\hline Glazed fenestration SHGC b, e & $\mathbf{N R}$ \\
\hline
\end{tabular}

a. R-values are minimums. U-factors and SHGC are maximums. R-19 batts compressed into a nominal $2 \times 6$ framing cavity such that the R-value is reduced by R-1 or more shall be marked with the compressed batt R-value in addition to the full thickness R-value.

b. The fenestration U-factor column excludes skylights. The SHGC column applies to all glazed fenestration.

c. "15/19" means R-15 continuous insulated sheathing on the interior or exterior of the home or R-19 cavity insulation at the interior of the basement wall. "10/13" means R-10 continuous insulated sheathing on the interior or exterior of the home or R-13 cavity insulation at the interior of the basement wall.

d. R-5 shall be added to the required slab edge R-values for heated slabs. Insulation depth shall be the depth of the footing or 2 feet, whichever is less in zones 1 through 3 for heated slabs.

e. There are no SHGC requirements in the Marine zone. 
f. Basement Wall Insulation is not required in warm-humid locations.

g. Or insulation sufficient to fill the framing cavity. R-19 is minimum.

h. "13+5" means R-13 cavity insulation plus R-5 insulated sheathing. If structural sheathing covers 25 percnt or less of the exterior, insulating sheathing is not required where structural sheathing is used. If structural sheathing covers more than 25 percent of exteriror, structural sheathing shall be supplemented with insulated sheathing of atleast R-2.

i. The second R-value applies when more than half the insulation is on the interior of the wall.

j. For impact rated fenestration complying with Section R301.2.1.2 of the International Residential Code or Section 1608.1.2 of the International Building code, the maximum U-factor shall be 0.75 in Zone 2 and 0.65 in Zone 3.

The equation used is:

$$
\mathrm{Q}=\mathrm{UA} \Delta \mathrm{T}
$$

Ideal Consumption $(9$ days $)=\left(\left(\right.\right.$ AreaFloor $\left./ R_{\text {Floor }}\right)+\left(\right.$ Areawalls $\left./ R_{\text {Floor }}\right)+\left(\right.$ AreaRoof $\left./ R_{\text {Roof }}\right)+($ Uwindows X Areawindows)) x Del T x 24 x 9 x 293/1,000,0000

Where,

$$
\begin{aligned}
\mathrm{U} & =\text { Overall Heat transfer coefficient, } \mathrm{BTU} /\left(\mathrm{h}^{\circ} \mathrm{F} \mathrm{ft} 2\right) \\
\mathrm{A} & =\text { Area, } \mathrm{ft}^{2} \\
\Delta T & =\text { Temperature difference (between inside and outside the house), }{ }^{0} \mathrm{~F}
\end{aligned}
$$

$($ Note: 1 MMBtu $=293 \mathrm{kWh})$

\subsubsection{Response}

The response of the model is calculated by dividing the ideal consumption (calculated) by the formula described above and the actual consumption which is the noted $\mathrm{kWh}$ consumption.

$$
\text { Res }=\frac{\text { Ideal Consumption }}{\text { Actual Consumption }}
$$

Where,

Res $=$ Response, no units

Actual Consumption $=$ Actual energy consumption noted from the utility meter, $\mathrm{kWh}$ 


\subsubsection{Variables in the Model}

The variables which are used in this research are described below. These variables have an effect on the response and are proved significant in the analysis explained in the next chapter.

\subsubsection{Area}

The area of the house has an effect on the heat loss and power consumption. Generally, bigger house have more leakage but the leakage also depends on the year the house was built in. The climatic conditions also play a significant role on the response factor of the house. Figure 1.9.4 documents the air leakage values from different parts in low-rise residential houses.

\subsubsection{Occupancy}

Human body emits some heat in the environment which depends upon the weight of the person and the activity done. The total amount of heat produced is equal to calories consumed minus the work done by the person. Table 3.3.3.2 gives the values of heat emitted at different levels of activities.

\begin{tabular}{|c|c|c|c|c|c|c|c|c|c|c|c|c|c|c|}
\hline \multirow{3}{*}{$\begin{array}{c}\text { Degree of } \\
\text { Activity }\end{array}$} & \multirow{3}{*}{$\begin{array}{c}\text { Typical } \\
\text { Application }\end{array}$} & $\begin{array}{c}\text { Average } \\
\text { Metabolic } \\
\text { rate - }\end{array}$ & \multicolumn{12}{|c|}{ Room Dry Bulb Temperature $\left({ }^{\circ} \mathrm{C}\right)$} \\
\hline & & $(W)$ & \multicolumn{2}{|c|}{28} & \multicolumn{2}{|c|}{27} & \multicolumn{2}{|c|}{26} & \multicolumn{2}{|c|}{24} & \multicolumn{2}{|c|}{22} & \multicolumn{2}{|c|}{20} \\
\hline & & & Sens. & Lat. & Sens. & Lat. & Sens. & Lat. & Sens. & Lat. & Sens. & Lat. & Sens. & Lat. \\
\hline $\begin{array}{l}\text { Seated at } \\
\text { rest }\end{array}$ & $\begin{array}{l}\text { Cinema, } \\
\text { theatre, } \\
\text { school }\end{array}$ & 100 & 50 & 50 & 55 & 45 & 60 & 40 & 67 & 33 & 72 & 28 & 79 & 21 \\
\hline $\begin{array}{l}\text { Seated, } \\
\text { very light } \\
\text { work }\end{array}$ & $\begin{array}{l}\text { Computer } \\
\text { working }\end{array}$ & 120 & 50 & 70 & 55 & 65 & 60 & 60 & 70 & 50 & 78 & 42 & 84 & 36 \\
\hline $\begin{array}{l}\text { Office } \\
\text { work }\end{array}$ & $\begin{array}{c}\text { Hotel } \\
\text { reception, } \\
\text { cashier }\end{array}$ & 130 & 50 & 80 & 56 & 74 & 60 & 70 & 70 & 60 & 78 & 52 & 86 & 44 \\
\hline $\begin{array}{l}\text { Standing, } \\
\text { walking } \\
\text { slowly }\end{array}$ & $\begin{array}{c}\text { Laboratory } \\
\text { work }\end{array}$ & 130 & 50 & 80 & 56 & 74 & 60 & 70 & 70 & 60 & 78 & 52 & 86 & 44 \\
\hline $\begin{array}{l}\text { Walking, } \\
\text { seated }\end{array}$ & & 150 & 53 & 97 & 58 & 92 & 64 & 86 & 76 & 74 & 84 & 66 & 90 & 60 \\
\hline $\begin{array}{l}\text { Moderate } \\
\text { work }\end{array}$ & $\begin{array}{c}\text { Servant, hair } \\
\text { dresser }\end{array}$ & 160 & 55 & 105 & 60 & 100 & 68 & 92 & 80 & 80 & 90 & 70 & 98 & 62 \\
\hline $\begin{array}{c}\text { Light } \\
\text { bench } \\
\text { work }\end{array}$ & $\begin{array}{l}\text { Mechanical } \\
\text { production }\end{array}$ & 220 & 55 & 165 & 52 & 158 & 70 & 150 & 85 & 135 & 100 & 120 & 115 & 105 \\
\hline $\begin{array}{l}\text { Moderate } \\
\text { Dancing }\end{array}$ & Party & 250 & 62 & 188 & 70 & 180 & 78 & 172 & 94 & 156 & 110 & 140 & 125 & 125 \\
\hline $\begin{array}{c}\text { Fast } \\
\text { walking }\end{array}$ & $\begin{array}{l}\text { Mountain } \\
\text { walking }\end{array}$ & 300 & 80 & 220 & 88 & 212 & 96 & 204 & 110 & 190 & 130 & 170 & 145 & 155 \\
\hline $\begin{array}{l}\text { Heavy } \\
\text { work }\end{array}$ & Athletics & 430 & 132 & 298 & 138 & 292 & 144 & 286 & 154 & 276 & 170 & 260 & 188 & 24 \\
\hline
\end{tabular}

Table 3.3.3.2: Sensible and Latent Heat Loss from Human 
For the empirical modeling of this experiment, we have used the value to be $256 \mathrm{Btu} / \mathrm{hr}$ per person.

\subsubsection{Air Changes Per Hour}

Air infiltration rate can vary from $0.1 \mathrm{ACH}$ to $1.5 \mathrm{ACH}$ depending on the weather conditions. Air infiltration depends on air leakage, pressure difference cause by temperature difference and forces of the wind.

$$
A C H=\frac{Q .60}{A . H}
$$

Where,

$$
\begin{aligned}
& \mathrm{ACH}=\text { Air changes per hour } \\
& \mathrm{A}=\text { Area, } \mathrm{ft}^{2} \\
& \mathrm{H}=\text { Height }, \mathrm{ft}
\end{aligned}
$$

The speed of wind has a considerable effect on the infiltration rate in the houses. At low wind speeds infiltration occurs mostly via stack effect and at high wind speeds, the enhanced air infiltration is driven by wind and temperature effect. [9]

$$
\mathrm{Q}=A_{L} \cdot \sqrt{C s . \Delta T+C w \cdot U^{2}}
$$

Where,

$$
\begin{aligned}
& \mathrm{A}_{\mathrm{L}}=\text { Leakage area }, \mathrm{in}^{2} \\
& \mathrm{Cs}=\text { Stack Coefficient } \\
& \Delta T=\text { Temperature Difference } \\
& \mathrm{CW}_{\mathrm{W}}=\text { Wind Coefficient } \\
& \mathrm{U}=\text { Wind Velocity }, \mathrm{mph}
\end{aligned}
$$

\subsection{Empirical Modeling}

The method used in this research to develop an equation for analyzing the effectiveness of the insulation of a residential house is regression analysis. A multiple linear regression was done between the response and variables: area, occupancy, temperature difference and air changes per 
hour. $\mathrm{ACH}$ include the effect of wind because the $\mathrm{CFM}_{50}$ readings from the blower door tests does not neglect the heat loss due to winds.

All the calculations were performed in MS Excel and the calculated values were imported to Minitab 15 software to develop the empirical model using Multiple Linear Regression (MLR). 


\begin{tabular}{|c|c|c|c|c|c|c|c|c|c|}
\hline S. No & $\begin{array}{l}\text { Building } \\
\text { Name }\end{array}$ & Apt No & $\begin{array}{c}\text { Actual } \\
\text { Consumption } \\
(\mathbf{k W h})\end{array}$ & $\begin{array}{c}\text { Ideal } \\
\text { Consumption } \\
(\mathbf{k W h})\end{array}$ & Response & $\begin{array}{c}\text { Area } \\
(\text { sq ft) }\end{array}$ & $\begin{array}{c}\text { Temp } \\
\text { Difference } \\
\left({ }^{0} \mathbf{F}\right)\end{array}$ & $\begin{array}{c}\text { No of } \\
\text { Residents }\end{array}$ & $\begin{array}{c}\text { Air } \\
\text { Changes } \\
\text { per } \\
\text { Hour } \\
\end{array}$ \\
\hline 1 & \multirow{5}{*}{ MTW } & 102 & 655 & 386 & 0.59 & 770 & 30.93 & 4 & 0.32 \\
\hline 2 & & 201 & 830 & 428 & 0.52 & 770 & 34.24 & 4 & 0.28 \\
\hline 3 & & 202 & 623 & 378 & 0.61 & 770 & 30.27 & 4 & 0.29 \\
\hline 4 & & 301 & 747 & 405 & 0.54 & 770 & 32.42 & 5 & 0.32 \\
\hline 5 & & 302 & 714 & 391 & 0.55 & 770 & 31.27 & 5 & 0.32 \\
\hline 6 & \multirow{6}{*}{775} & 1 & 244 & 405 & 1.66 & 667 & 37.39 & 3 & 0.58 \\
\hline 7 & & 3 & 431 & 418 & 0.97 & 667 & 38.55 & 2 & 0.58 \\
\hline 8 & & 102 & 316 & 407 & 1.29 & 667 & 37.61 & 2 & 0.50 \\
\hline 9 & & 203 & 199 & 377 & 1.89 & 667 & 34.80 & 2 & 0.91 \\
\hline 10 & & 205 & 347 & 394 & 1.13 & 667 & 36.38 & 6 & 0.88 \\
\hline 11 & & 4 & 180 & 372 & 2.07 & 667 & 34.35 & 3 & 0.59 \\
\hline 12 & \multirow{4}{*}{777} & 1 & 389 & 405 & 1.04 & 667 & 37.39 & 3 & 0.58 \\
\hline 13 & & 2 & 185 & 373 & 2.02 & 667 & 34.45 & 1 & 0.59 \\
\hline 14 & & 103 & 351 & 417 & 1.19 & 667 & 38.53 & 2 & 0.50 \\
\hline 15 & & 106 & 245 & 367 & 1.50 & 667 & 33.90 & 2 & 0.51 \\
\hline
\end{tabular}

Table 3.4: Data Set for Empirical Modeling 


\section{CHAPTER 4}

\section{DESIGN AND DEVELOPMENT OF MODEL}

Multiple linear regression (MLR) is a method used to model the linear relationship between a dependent variable (predictand) and one or more independent variables (predictors). The predictors used in the study are variables (inside and outside the house) that effect the response of thermal barriers or insulation. All the values of predictands have been recorded and documented for this study. None of the predictands are calculated or assumed. The predictors and predictands were analyzed by means of multiple linear regression (MLR) using the Minitab 15 program. The various stages in the design and development of the model are explained below

\subsection{Insulation Effectiveness Study Data Analysis}

The data in this study were obtained by installing data loggers, performing blower door tests, walk-around data collection from houses and from trusted weather data websites. These data values can be found in chapter 3 . The data were formatted into a spreadsheet and analyzed. All data houses which were rejected had one or more reasons in common from the following table.

\begin{tabular}{|c|c|}
\hline S.No. & Reason for Rejection \\
\hline 1. & Houses in apartment buildings with centralized heating \\
\hline 2. & Houses with any type of gas usage \\
\hline 3. & Houses with area more than $800 \mathrm{sq} \mathrm{ft}$ \\
\hline 4. & Houses with a heating setback control \\
\hline
\end{tabular}

The exception made for the data houses was in house no 203 and 205 in building 775 . The recorded $\mathrm{CFM}_{50}$ value was significantly than the expected value. But due to considerable explanations for this anomaly, these high values were deemed correct for the model. The houses with gas usage could not be populated in the model because it was not safe to perform the blower door tests in those houses as it would have risked the forced convection of carbon monoxide inside the house. Houses with more than $800 \mathrm{ft}^{2}$ were not used in the model to avoid any outliers. 


\subsection{Predictors for Multiple Linear Regression}

The predictors chosen in MLR are area, temperature difference, number of occupants and $\mathrm{ACH}$ (air changes per hour). The area of the house increases the energy usage and also the energy lost by walls and it is observed that the leakage in older and big houses is comparatively more. The temperature difference has a positive relationship with the response, it increases the energy usage. The number of occupants decrease the energy used in the house by adding heat to the system. The ACH is dependent on the leakage area of the house. It is directly proportional to the kWh used. The scatter plots of response with all the predictors are shown in Figures below.

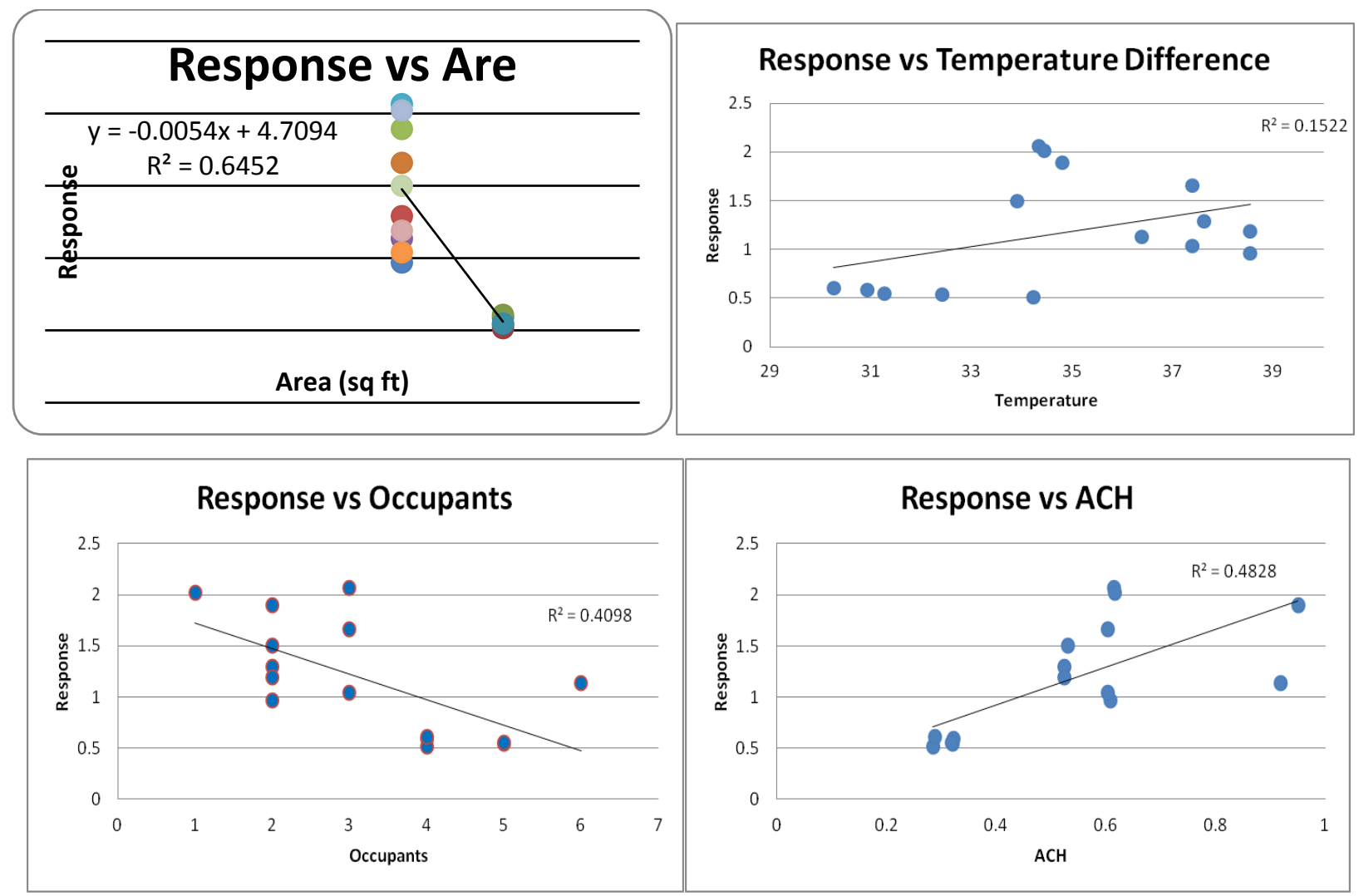

Figure 4.2: Plots of Response (Predictands) with all the variables.

The reason for comparatively low coefficients of determination than the final regression equation (explained later in the chapter) for linear fitted values shown in the graphs above is that all the data points were randomly collected and there may not be a linear relationship with the response. Also the response is affected by many other factors like climatic zone, setback control, type of 
insulation, grade and type of heating equipment. The scope of this experiment did not allow the use of these variables.

\subsection{Using Multiple Linear Regression to Determine First Order Coefficient}

Multiple linear regression is a method used to model the linear relationship between a dependent variable (predictand) and one or more independent variables (predictor).

The coefficient of determination $\left(\mathrm{R}^{2}\right)$ is the proportion of variance accounted for, explained, or described by regression.

\subsection{Model}

Multiple linear regression (MLR) was performed using the three predictand response R (Ideal Energy consumption/actual energy consumption), and the predictors: area, temperature difference, number of occupants, air changes per hour, natural $\mathrm{CFM}, \ln (\mathrm{ACH})$ and $\ln ($ natural CFM). The response trials were used to narrow down the results obtained by the regression analysis. Table 4.4 shows the response and predictors used to develop the model. 


\begin{tabular}{|c|c|c|c|c|c|c|c|c|c|}
\hline S. No & $\begin{array}{l}\text { Building } \\
\text { Name }\end{array}$ & Apt No & $\begin{array}{c}\text { Actual } \\
\text { Consumption } \\
(\mathbf{k W h})\end{array}$ & $\begin{array}{c}\text { Ideal } \\
\text { Consumption } \\
(\mathbf{k W h})\end{array}$ & Response & $\begin{array}{c}\text { Area } \\
(\text { sq ft })\end{array}$ & $\begin{array}{c}\text { Temp } \\
\text { Difference }\end{array}$ & $\begin{array}{c}\text { No of } \\
\text { Occupants }\end{array}$ & $\begin{array}{c}\text { Air } \\
\text { Changes } \\
\text { per } \\
\text { Hour } \\
\end{array}$ \\
\hline 1 & \multirow{5}{*}{ MTW } & 102 & 655 & 386 & 0.59 & 770 & 30.93 & 4 & 0.32 \\
\hline 2 & & 201 & 830 & 428 & 0.52 & 770 & 34.24 & 4 & 0.28 \\
\hline 3 & & 202 & 623 & 378 & 0.61 & 770 & 30.27 & 4 & 0.29 \\
\hline 4 & & 301 & 747 & 405 & 0.54 & 770 & 32.42 & 5 & 0.32 \\
\hline 5 & & 302 & 714 & 391 & 0.55 & 770 & 31.27 & 5 & 0.32 \\
\hline 6 & \multirow{6}{*}{775} & 1 & 244 & 405 & 1.66 & 700 & 37.39 & 3 & 0.58 \\
\hline 7 & & 3 & 431 & 418 & 0.97 & 700 & 38.55 & 2 & 0.58 \\
\hline 8 & & 102 & 316 & 407 & 1.29 & 700 & 37.61 & 2 & 0.50 \\
\hline 9 & & 203 & 199 & 377 & 1.89 & 700 & 34.80 & 2 & 0.91 \\
\hline 10 & & 205 & 347 & 394 & 1.13 & 700 & 36.38 & 6 & 0.88 \\
\hline 11 & & 4 & 180 & 372 & 2.07 & 700 & 34.35 & 3 & 0.59 \\
\hline 12 & \multirow{4}{*}{777} & 1 & 389 & 405 & 1.04 & 700 & 37.39 & 3 & 0.58 \\
\hline 13 & & 2 & 185 & 373 & 2.02 & 700 & 34.45 & 1 & 0.59 \\
\hline 14 & & 103 & 351 & 417 & 1.19 & 700 & 38.53 & 2 & 0.50 \\
\hline 15 & & 106 & 245 & 367 & 1.50 & 700 & 33.90 & 2 & 0.51 \\
\hline
\end{tabular}

Table 4.4 (a): Predictand and Predictors for Multiple Linear Regression Analysis

\begin{tabular}{|c|c|c|}
\hline Variable & Lower Limit & Upper Limit \\
\hline Area $\left(\mathrm{ft}^{2}\right)$ & 700 & 370 \\
\hline Temperature Difference (F) & 30.27 & 6 \\
\hline Number of Occupants & 1 & 0.91 \\
\hline Air Changes per Hour & 0.28 & 65 \\
\hline
\end{tabular}

Table 4.4 (b): Boundary Limits for Variables in the Model 
In the first case, regression for thermal barrier response was done using all the variables: area, temperature difference, number of occupants and natural ACH. It should be noted that predictors: natural $\mathrm{ACH}$, natural $\mathrm{CFM}, \ln (\mathrm{ACH})$ and $\ln (\mathrm{nCFM})$ are all variables derived from the same quantity. Hence, only one of these variables can be used as a predictor in the model. Similarly, in the next case only three variables were used and so on one variable was neglected in every case. After these four cases, the variables $\mathrm{ACH}$, natural $\mathrm{CFM}, \ln (\mathrm{ACH})$ and $\ln (\mathrm{nCFM})$ were regressed one by one in the model. Table 4.4 (b) shows the different multiple linear regressions, the predictor, the coefficients and the corresponding coefficient of determination. (Complete results of all the regression trials are documented in the Appendix).

As shown in table 4.4 (b), the coefficient of determination $\left(\mathrm{R}^{2}\right)$ and the adjusted coefficient of determination (adj $\mathrm{R}^{2}$ ) for all multiple linear regression iterations were in the range of $72.3 \%$ to $84.7 \%$. This signifies that there was not very much difference in $\mathrm{R}^{2}$ values but there was not enough explanation for the use of transformation values $(\ln (\mathrm{ACH})$ and $\ln (\mathrm{nCFM}))$ though the model demonstrated a better P-value by using the $\ln (\mathrm{ACH})$ and $\ln (\mathrm{nCFM})$ predictors.

After performing Multiple Linear Regression (MLR) analysis on different combination of predictand and predictors, it was concluded that the MLR with response vs area, temperature difference, number of occupants and Air Changes per Hour produced the best results and best fit. The P-value associated with $\mathrm{ACH}$ was 0.50 , which concludes that the variable is not very significant in the equation but mathematically it is proved that there is a direct positive relationship between the energy consumed for heating and the air leakage (which affects ACH). 


\begin{tabular}{|c|c|c|c|c|c|c|c|c|c|c|}
\hline $\begin{array}{c}\text { Trial } \\
\text { Number }\end{array}$ & Predictand & Coefficient & Area & Del T & Occupants & $\mathrm{ACH}$ & nCFM & $\ln (\mathrm{nCFM})$ & $\ln (\mathrm{ACH})$ & R-sq \\
\hline 1 & $\mathrm{R}$ & 13.96 & -0.01 & -0.12 & -0.10 & 0.50 & - & - & - & 84.9 \\
\hline 2 & $\mathrm{R}$ & 2.6309 & - & -0.0488 & -0.2417 & 2.0465 & - & - & - & 78.9 \\
\hline 3 & $\mathrm{R}$ & 3.2599 & -0.0031 & - & -0.1601 & 1.1891 & - & - & - & 73.2 \\
\hline 4 & $\mathrm{R}$ & 17.4523 & -0.0160 & -0.0565 & - & -0.1440 & - & - & - & 82.1 \\
\hline 5 & $\mathrm{R}$ & 16.2495 & -0.0142 & -0.1387 & -0.0775 & - & - & - & - & 84.3 \\
\hline 6 & $\mathrm{R}$ & 14.1239 & -0.0119 & -0.1284 & -0.1067 & - & 0.0057 & - & - & 85.0 \\
\hline 7 & $\mathrm{R}$ & 12.3374 & -0.0111 & -0.1268 & -0.1103 & - & - & 0.3788 & - & 85.0 \\
\hline 8 & $\mathrm{R}$ & 13.6851 & -0.0106 & -0.1268 & -0.1103 & - & - & - & 0.3788 & 85.1 \\
\hline
\end{tabular}

Table 4.4 (c): Plots of Response (Predictand) with all the variables. 


\subsubsection{Final Equation, Coefficients and ANOVA}

The final empirical equation is:

Response $=13.96-0.0117$ Area -0.1284 Del T -0.1067 Occupants +0.5089 ACH

Where,

\begin{tabular}{|c|c|}
\hline Response & $\begin{array}{c}\text { Ratio of Ideal Energy Consumption and Actual Energy } \\
\text { Consumption }\end{array}$ \\
\hline$\beta_{0}$ & First Coefficient \\
\hline Area & Area of House \\
\hline Del T & Difference between house temperature and ambient temperature \\
\hline Occupants & Number of occupants in the house \\
\hline ACH & Air Changes per hour \\
\hline
\end{tabular}

Table 4.4.1 (a) shows the parameter estimates for the model. The table shows the predictors, coefficients, standard error of coefficients, T-test and P-test values. It should be noted that the standard error coefficient and P-test value of $\mathrm{ACH}$ predictor is quite high and is not considered very significant in the empirical equation. But mathematically, it has been proved that there is a significant effect of $\mathrm{ACH}$ and it cannot be neglected. This relation is proved in the following equations.

$$
\begin{gathered}
\mathrm{Q}=A_{L} \cdot \sqrt{C s . \Delta T+C w \cdot U^{2}} \\
A C H=\frac{60 \cdot Q}{V}
\end{gathered}
$$

Where,
$\mathrm{A}_{\mathrm{L}}=$ Leakage area, in ${ }^{2}$
Cs = Stack Coefficient
$\Delta T=$ Temperature Difference
$\mathrm{CW}_{\mathrm{W}}=$ Wind Coefficient
$\mathrm{U} \quad=$ Wind Velocity, $\mathrm{mph}$
$\mathrm{Q}=$ Heat Loss
$\mathrm{ACH}=$ Air Changes Per Hour 


\begin{tabular}{|c|c|c|c|c|}
\hline Predictor & Coeff & SE Coeff & T & P \\
\hline Constant & 9.913 & 3.14 & 3.16 & 0.01 \\
\hline Area & -0.006639 & 0.002691 & -2.47 & 0.033 \\
\hline Del T & -0.12356 & 0.04397 & -2.81 & 0.018 \\
\hline Occupants & -0.10248 & 0.07417 & -1.38 & 0.197 \\
\hline ACH & 0.467 & 0.6817 & 0.69 & 0.509 \\
\hline
\end{tabular}

Table 4.4.1 (a): Parameter Estimates of the Empirical Model

\begin{tabular}{|c|c|}
\hline \multicolumn{2}{|c|}{ Regression Statistics } \\
\hline Multiple R & 0.92 \\
\hline R Square & 0.85 \\
\hline Adjusted R Square & 0.78 \\
\hline Standard Error & 0.26 \\
\hline Observations & 15 \\
\hline
\end{tabular}

Table 4.4.1 (b): Summary of Fit

\begin{tabular}{|c|c|c|c|c|c|}
\hline & Df & $\begin{array}{c}\text { Sum of } \\
\text { Squares }\end{array}$ & $\begin{array}{c}\text { Mean } \\
\text { Square }\end{array}$ & F & Significance F \\
\hline Regression & 4 & 3.6645 & 0.9161 & 13.6743 & 0.0005 \\
\hline Residual & 10 & 0.6700 & 0.0670 & - & - \\
\hline Total & 14 & 4.3344 & - & - & - \\
\hline
\end{tabular}

Table 4.4.1 (c): Analysis of Variance (ANOVA) 

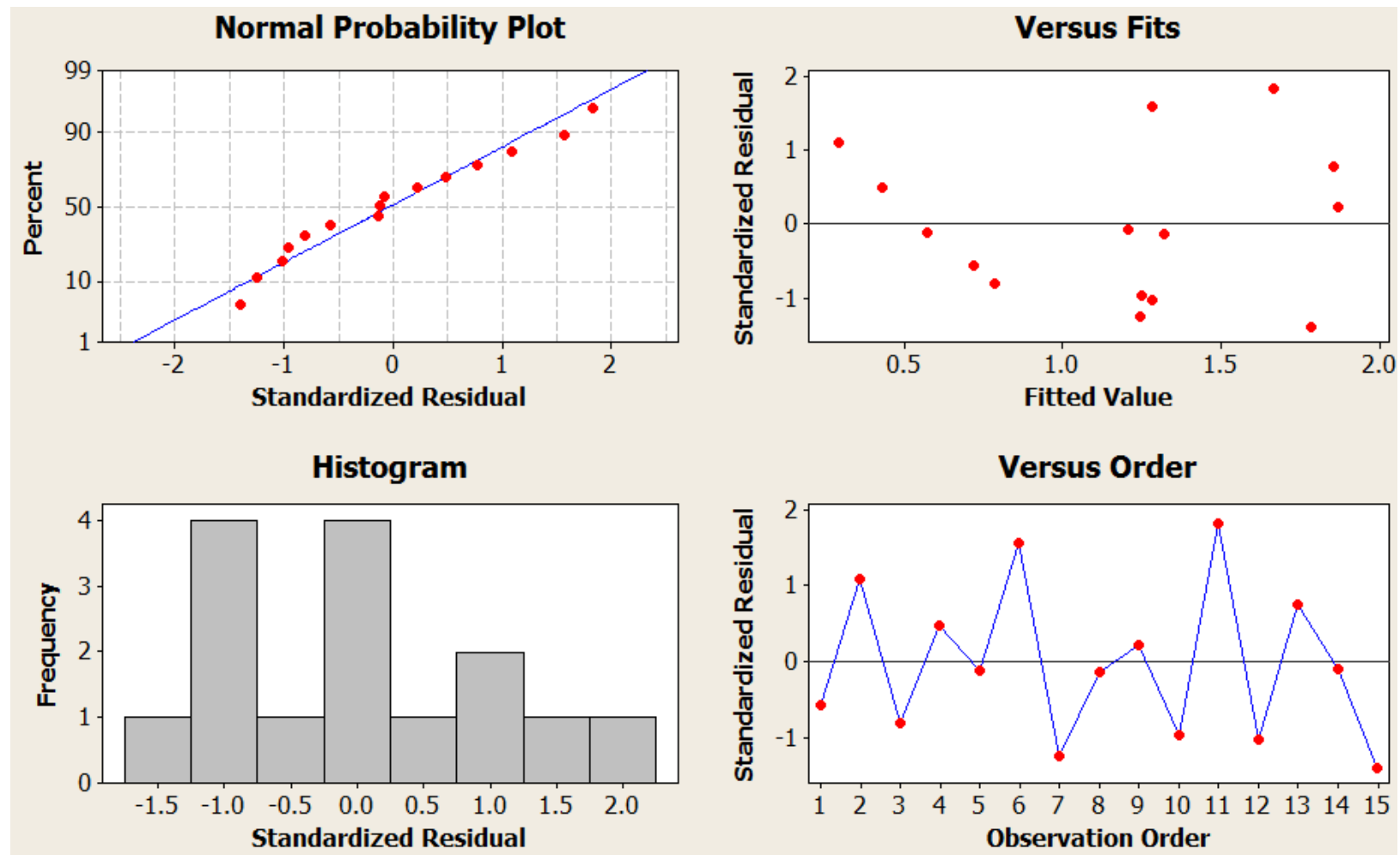

Figure 4.4.1: Residual Plots for Response 


\section{CHAPTER 5 \\ MODEL VALIDATION AND RESULTS}

\subsection{Model Execution}

This chapter deals with the execution of empirical model by using real-time data from one of the buildings from which data was collected during the conduct of this research. The goal here is to present the data collected from the site visits and demonstrate its use in the model inputs section.

\subsection{Model Inputs:}

The data collection has been done through installing the data loggers again and doing the blower door test again to get the CFM50 reading. Extensive details on area, temperature difference, and house parameters were collected during the house visits. The following sections utilize data collected to illustrate the workings of the empirical model. However, the models can be applied to variety of parameters as considered and reported earlier. It should be noted that not all response variables will be applicable to specific indoor and outdoor conditions.

Since all the parameter and their affects were discussed in detail in the previous section, this section will exclusively focus on the calculations and the values for outputs in table format. The details of the two houses will be discussed as House A and House B.

\subsubsection{House A:}

The product parameters:

Area: $667 \mathrm{ft}^{2}$

Height: $8 \mathrm{ft}$

Temperature Difference: $31.11^{\circ} \mathrm{F}$

Occupants: 2

CFM50: $935 \mathrm{cfm}$

Now the next step would be to convert the $\mathrm{CFM}_{50}$ to natural $\mathrm{ACH}$ :

$$
\text { Natural CFM }=\frac{\text { CFM50 }}{n}
$$




$$
\begin{aligned}
\text { Natural CFM } & =\frac{935}{18.2} \\
& =51.5 \mathrm{cfm}
\end{aligned}
$$

Now, to convert cfm to air changes per hour:

$$
\begin{aligned}
\mathrm{ACH}= & \frac{\text { Natural CFM } \times 60}{\text { Area } \times \text { Height }} \\
& =\frac{51.5 \times 60}{667 \times 8} \\
& =0.58 \mathrm{ACH}
\end{aligned}
$$

The model was populated with data collected from the house A. The response results were obtained from the model and screenshots are provided in the section below.

The equation is as follows:

$$
\begin{aligned}
& \text { Response }=13.96-0.0117 \text { Area }-0.1284 \text { Del T }-0.1067 \text { Occupants }+0.5089 \text { ACH } \\
&=13.96-(0.0117 \times 667)-(0.1284 \times 31.11)-(0.1067 \times 3)+(0.5089 \times 0.58) \\
&=2.25 \\
&=((667 / 38)+(832 / 13)+(667 / 10)+(0.5 * 60) \times 31.11) * 24 * 9 * 293 / 1000000 \\
&=351 \mathrm{kWh} \\
& \quad(1 \mathrm{MMBtu}=293 \mathrm{kWh})
\end{aligned}
$$

$\mathrm{kWh}$ consumption $=$ Ideal Consumption / Response

$$
\begin{aligned}
& =351 / 2.25 \\
& =156 \mathrm{kWh}
\end{aligned}
$$




\subsubsection{House B:}

The product parameters:

Area: $667 \mathrm{ft}^{2}$

Height: $8 \mathrm{ft}$

Temperature Difference: $33.55^{\circ} \mathrm{F}$

Occupants: 3

CFM50: $940 \mathrm{cfm}$

Now the next step would be to convert the $\mathrm{CFM}_{50}$ to natural $\mathrm{ACH}$ :

$$
\begin{aligned}
\text { Natural CFM } & =\frac{\text { CFM50 }}{n} \\
\text { Natural CFM } & =\frac{940}{18.2} \\
& =51.6 \mathrm{cfm}
\end{aligned}
$$

Now, to convert cfm to air changes per hour:

$$
\begin{aligned}
\mathrm{ACH}= & \frac{\text { Natural CFM } \times 60}{\text { Area } \times \text { Height }} \\
& =\frac{51.6 \times 60}{667 \times 8} \\
& =0.58 \mathrm{ACH}
\end{aligned}
$$

The model was populated with data collected from the house A. The response results were obtained from the model and screenshots are provided in the section below.

The equation is as follows:

Response $=13.96-0.0117$ Area -0.1284 Del T -0.1067 Occupants +0.5089 ACH 


$$
\begin{aligned}
& =13.96-(0.0117 \times 667)-(0.1284 \times 33.55)-(0.1067 \times 3)+(0.5089 \times 0.58) \\
& =1.83 \\
& =((667 / 38)+(832 / 13)+(667 / 10)+(0.5 * 60) \times 33.55) * 24 * 9 * 293 / 1000000 \\
& =378 \mathrm{kWh} \\
& (1 \mathrm{MMBtu}=293 \mathrm{kWh})
\end{aligned}
$$

$\mathrm{kWh}$ consumption $=$ Ideal Consumption $/$ Response

$$
\begin{aligned}
& =378 / 1.83 \\
& =207 \mathrm{kWh}
\end{aligned}
$$

This value matches with the energy consumption values recorded for this period and will be verified through energy bills too. 


\subsection{Results and Discussion}

The model has been populated with the data collected in the host houses and results were obtained. The calculations on different losses and heat inputs were discussed in section 5.2. Table 5.2 compared the actual energy consumption with predicted energy consumption. The actual consumption was observed for one day and then was extrapolated for nine days. An average error of $15 \%$ is noted between the predicted values and the actual values of energy consumption. Table 5.3 shows the model values of energy consumption, actual values of energy consumption and the error found in the model.

\begin{tabular}{|c|c|c|c|}
\hline & $\begin{array}{c}\text { Energy Consumption } \\
\text { from the Model }(\mathbf{k W h})\end{array}$ & $\begin{array}{c}\text { Actual Energy } \\
\text { Consumption }(\mathbf{k W h})\end{array}$ & Error \\
\hline House A & 156 & 184 & $15.21 \%$ \\
\hline House B & 207 & 231 & $13.04 \%$ \\
\hline
\end{tabular}

Table 5.3: Comparison of Results

This section verifies that the model is valid and holds good within the $20 \%$ error limits and subsets of the range of the values used to populate the empirical model.

This model can be used to predict the energy consumption and the effectiveness of the thermal envelope within the limitations. The limitations of this model are:

1. The area of the house should not exceed $770 \mathrm{sq} f \mathrm{ft}$.

2. The thermostat inside the house should not be calibrated and it should not be programmed for setback control

3. The model cannot be used for summer months

4. The model can give readings with $30 \%$ error

5. The empirical model produce meaningful results only when the variables are in the ranges of values used to develop the empirical equation

6. ACH will have to be estimated as it is not possible to perform a blower door test every time the equation/model is used. 


\section{Suggestions to Home Owners:}

1. The variables should be within the limits as mentioned in Table 4.4 (b) to avoid absurd and negative response values.

2. For calculating $\mathrm{ACH}$, following steps should be followed:

a. Calculate effective leakage area using the following table

\begin{tabular}{|c|c|c|c|c|}
\hline & Units & Best Estimate & Minimum & Maximum \\
\hline Ceiling & in2/ft2 & 0.026 & 0.011 & 0.04 \\
\hline $\begin{array}{c}\text { Door Frame, } \\
\text { Wood }\end{array}$ & in2/ft2 & 0.004 & 0.001 & 0.004 \\
\hline Door, General & in2/ft2 & 0.015 & 0.011 & 0.021 \\
\hline Electrical outlets & in2/ea & 0.023 & 0.012 & 0.12 \\
\hline $\begin{array}{c}\text { Ceiling-wall } \\
\text { joint }\end{array}$ & in2/lfte & 0.07 & 0.0075 & 3.1 \\
\hline $\begin{array}{c}\text { Vents } \\
\text { cavity wall }\end{array}$ & in2/ea & 1.6 & 0.39 & 0.033 \\
\hline $\begin{array}{c}\text { Windows, not } \\
\text { weatherstripped }\end{array}$ & in2/ft2 & 0.0098 & 0.0007 & 0.035 \\
\hline
\end{tabular}

b. Calculate CFM50:

$$
\mathrm{CFM}_{50}=\mathrm{ELA} \times 10
$$

c. Calculate natural CFM:

$$
\text { Natural CFM }=\frac{\text { CFM50 }}{n}
$$

d. Convert natural cfm to air changes per hour: 


$$
\mathrm{ACH}=\frac{\text { Natural CFM } \times 60}{\text { Area } \times \text { Height }}
$$

Where,

$\mathrm{n}=$ Lawrence Berkeley Laboratory $(\mathrm{LBL}) \mathrm{n}$ factor for ventilation, 18.2

3. Once the response and all the variables are known, the effectiveness of thermal insulation can be assessed using the following table.

\begin{tabular}{|c|c|c|}
\hline Response & Rating & Description \\
\hline Less than 1 & Bad & Action needed immediately \\
\hline Equal to 1 & OK & $\begin{array}{c}\text { No action required but may } \\
\text { require in near future }\end{array}$ \\
\hline Greater than 1 & Good & No action required \\
\hline
\end{tabular}

Table 5.3: Effectiveness Rating in Residential Households 


\section{CHAPTER 6}

\section{CONCLUSION AND FUTURE WORK}

\subsection{Conclusion}

Based on the data analysis done by Multiple Linear Regression technique, an empirical equation was formulated to calculate the response if the variables, area, temperature difference and air changes per hour is known.

The response rating was developed after assessing the houses and analyzing the utility bills of the houses which were used to formulate the empirical equations. These equations are

empirically correct because they meet the MLR assumptions; the $\mathrm{R}^{2}$ values are quite high for an experimental study, which signifies that they explain considerable part of the observed variation in the data. Also, the results obtained from the empirical equation for the calculation of response are in close proximity with the experimental values. Consequently, these equations are reliable predictors of response and effectiveness of thermal barrier of a household insulation.

Empirical equations were also formulated by using a combination of other variables but the the fit was obtained using the final four variables mentioned above. Most of the MLR equations produced satisfactory results and yielded high $\mathrm{R}^{2}$ values. Some of the equations violated the MLR assumptions and hence were considered unreliable to be used. The empirical model was validating by testing the value of response from the empirical equation and then comparing it with the energy consumption in $\mathrm{kWh}$ in real time.

To check the robustness of the empirical equations, various random values were used to generate response functions and the results concluded the following limitations in the empirical model explained in the Table below.

\begin{tabular}{|c|c|c|}
\hline S.NO & Limitation & Reason \\
\hline 1. & Size of the house & No outlier population \\
\hline 2. & Season & Only heavy winter season could be used \\
\hline
\end{tabular}




\section{Table 6.1 (a): Limitation of the Empirical Model}

Therefore the final conclusions of the study are as follows.

1. A good estimate of a house's insulation effectiveness and the energy consumption in the form of electricity can be found out using the model equation developed.

2. The model will have outliers in specific cases.

3. The model equation is developed only for small apartments and for zone 5 winter season.

4. The model can be used to rate the effectiveness of house insulation.

\subsection{Future Work}

The ongoing research and more data points are required to make the model more reliable. Any system has to be refined by including minute details that can affect the system output. The development of empirical model in this study has given a feasible methodology to help the house owners to analyze their furnace heating utilization and insulation effectiveness for determining whether the house need any commissioning or retro-commissioning. However, the following work would further improve the appearance, comfort, robustness, and credibility of the empirical model.

1. Populating the model with more data points to get good significance on $\mathrm{ACH}$ variable.

2. The heating energy consumption used in the model should be obtained by installing a current transducer.

3. The temperature difference readings and energy consumption reading should be taken at small intervals for long periods to retrieve more accurate data.

4. The model should also include data from houses which have more than one floor and whose area is more than $770 \mathrm{sq} \mathrm{ft}$. 
5. The model should also include data from houses which are located outside West Virginia which have more than one floor and whose area is more than $770 \mathrm{sq} f t$ to make it more robust and valid in other parts of the world.

6. Evaluate more accurate ideal heating energy consumption by simulating the houses in eQUEST.

7. The model should be validated on an experimental model house where the variables can be varied and the response/results are already known. 


\section{APPENDIX C}

\section{Multiple Linear Regression Reports from Minitab 15}

To provide a better understanding of the various data and plots, an explanation of the different components is presented below.

Summary of Fit Table

- "R Square" $\left(\mathrm{R}^{2}\right)$ is the coefficient of determination, which is the proportion of variance accounted for, explained, or described by the regression model. If the regression is perfect, the $\mathrm{R}^{2}$ value is one. If the regression is a failure and the sum of squares of errors equals the total sum of squares, no variance is accounted for by regression and $\mathrm{R}^{2}$ is zero.

- "R Square Adj" is the adjusted $\mathrm{R}^{2}$ value, which measures the proportion of the variation in the predictand accounted for by the predictors. Adjusted $\mathrm{R}^{2}$ allows for the degrees of freedom associated with the sums of squares.

- "Root Mean Square Error" is the square of the differences between values predicted by a model and the observed values being modeled.

- "Mean of Response" is the values of the predictand calculated from the regression parameters and a given value of the predictor. This is an estimate of the mean of the predictand associated with an explanatory value of the predictor. The mean of response is used in the plots as a horizontal reference point.

- "Observations" are the number of data points used in the regression model.

Analysis of Variance Table

- "Source" has three rows, one for total variability and one for each of the two pieces comprising the total, Model or Regression, and Error or Residual. The "C" in "C Total" stands for corrected.

- "DF" is the degrees of freedom. For the Model, the number of degrees of freedom is the number of predictors used for the regression. For the Error, the degrees of freedom is the 
number of observations minus the number of predictors minus 1 . The degrees of freedom for $\mathrm{C}$ Total is the sum of the degrees of freedom for the Model and the Error.

- "Sum of Squares" is a way to find the function which best fits (least varies) from the data. It is the total variability in the response which is calculated from $\sum(y-\bar{y})^{2}$, where $\bar{y}$ is the sample mean. The "Corrected" in "C Total" refers to subtracting the sample mean before squaring. The amount of variation in the data that cannot be accounted for by this simple method of prediction is given by the total sum of squares. When the regression model is used for prediction, the uncertainty that remains is the variability about the regression line, $\sum(\mathrm{y}-\hat{y})^{2}$, where $\hat{y}$ is the predicted value of the predictand. This is the Error sum of squares. The difference between the Total sum of squares and the Error sum of squares is the Model sum of squares, which is equal to $\sum(\hat{\mathrm{y}}-\overline{\mathrm{y}})^{2}$.

- "Mean Squares" are the sum of squares divided by the corresponding degrees of freedom.

- "F Ratio" is the test statistic used to decide whether a model as a whole has a statistically significant predictive capability, that is, whether the regression sum of squares is big enough, considering the number of variables needed to achieve it. F is the ratio of the Model mean square to the Error mean square.

\section{Parameter Estimates Table}

- 'Term" is the predictor.

- "Estimate' is the regression coefficients in the regression equation.

- "Standard Error" is an estimate of the standard deviation of the regression coefficients.

- "t ratio" tests the hypothesis that a population regression coefficient is 0 when the other predictors are in the model. It is the ratio of the sample regression coefficient to its standard error. 
The different models which were tested during the development of final equation are as follows:

1. Regression Analysis: Response versus Del T, Occupants, ACH

\begin{tabular}{|c|c|c|c|c|}
\hline Predictor & Coeff & SE Coeff & T & P \\
\hline Constant & 2.631 & 1.44 & 1.83 & 0.095 \\
\hline Del T & -0.04881 & 0.04148 & -1.18 & 0.264 \\
\hline Occupants & -0.24173 & 0.06969 & -3.47 & 0.005 \\
\hline ACH & 2.0466 & 0.5417 & 3.78 & 0.003 \\
\hline
\end{tabular}

Parameter Estimates of the Empirical Model

\begin{tabular}{|c|c|}
\hline \multicolumn{2}{|c|}{ Regression Statistics } \\
\hline Multiple R & 0.866468 \\
\hline R Square & 0.750767 \\
\hline Adjusted R Square & 0.682794 \\
\hline Standard Error & 0.331462 \\
\hline Observations & 15 \\
\hline
\end{tabular}

\section{Summary of Fit}

\begin{tabular}{|c|c|c|c|c|c|}
\hline & Df & $\begin{array}{c}\text { Sum of } \\
\text { Squares }\end{array}$ & $\begin{array}{c}\text { Mean } \\
\text { Square }\end{array}$ & F & Significance F \\
\hline Regression & 4 & 3.6645 & 0.9161 & 13.6743 & 0.0005 \\
\hline Residual & 10 & 0.6700 & 0.0670 & - & - \\
\hline Total & 14 & 4.3344 & - & - & - \\
\hline
\end{tabular}

Analysis of Variance (ANOVA) 
2. Regression Analysis: Response versus Area, Occupants, ACH

\begin{tabular}{|c|c|c|c|c|}
\hline Predictor & Coeff & SE Coeff & T & P \\
\hline Constant & 3.26 & 3.19 & 1.02 & 0.33 \\
\hline Area & 0.00 & 0.00 & -0.72 & 0.49 \\
\hline Occupants & -0.16 & 0.10 & -1.68 & 0.12 \\
\hline ACH & 1.19 & 0.90 & 1.33 & 0.21 \\
\hline
\end{tabular}

Parameter Estimates of the Empirical Model

\begin{tabular}{|c|c|}
\hline \multicolumn{2}{|c|}{ Regression Statistics } \\
\hline Multiple R & 0.86 \\
\hline R Square & 0.73 \\
\hline Adjusted R Square & 0.66 \\
\hline Standard Error & 0.34 \\
\hline Observations & 15 \\
\hline
\end{tabular}

Summary of Fit

\begin{tabular}{|c|c|c|c|c|c|}
\hline & Df & $\begin{array}{c}\text { Sum of } \\
\text { Squares }\end{array}$ & $\begin{array}{c}\text { Mean } \\
\text { Square }\end{array}$ & F & Significance F \\
\hline Regression & 3.0 & 3.5 & 1.2 & 10.0 & 0.0018 \\
\hline Residual & 11.0 & 1.3 & 0.1 & & \\
\hline Total & 14.0 & 4.8 & & & \\
\hline
\end{tabular}

Analysis of Variance (ANOVA) 
3. Regression Analysis: Response versus Area, Temperature Difference, ACH

\begin{tabular}{|c|c|c|c|c|}
\hline Predictor & Coeff & SE Coeff & T & P \\
\hline Constant & 17.45 & 3.96 & 4.41 & 0.00 \\
\hline Area & -0.02 & 0.00 & -4.59 & 0.00 \\
\hline ACH & -0.06 & 0.65 & -0.09 & 0.93 \\
\hline Del T & -0.14 & 0.05 & -3.11 & 0.01 \\
\hline
\end{tabular}

Parameter Estimates of the Empirical Model

\begin{tabular}{|c|c|}
\hline \multicolumn{2}{|c|}{ Regression Statistics } \\
\hline Multiple R & 0.91 \\
\hline R Square & 0.82 \\
\hline Adjusted R Square & 0.77 \\
\hline Standard Error & 0.28 \\
\hline Observations & 15 \\
\hline
\end{tabular}

Summary of Fit

\begin{tabular}{|c|c|c|c|c|c|}
\hline & Df & $\begin{array}{c}\text { Sum of } \\
\text { Squares }\end{array}$ & $\begin{array}{c}\text { Mean } \\
\text { Square }\end{array}$ & F & Significance F \\
\hline Regression & 3 & 3.98 & 1.33 & 16.84 & 0.000201 \\
\hline Residual & 11 & 0.87 & 0.08 & & \\
\hline Total & 14 & 4.85 & & & \\
\hline
\end{tabular}

Analysis of Variance (ANOVA) 
4. Regression Analysis: Response versus Area, Temperature Difference, Occupants

\begin{tabular}{|c|c|c|c|c|}
\hline Predictor & Coeff & SE Coeff & T & P \\
\hline Constant & 16.25 & 3.04 & 5.34 & 0.00 \\
\hline Area & -0.01 & 0.00 & -5.39 & 0.00 \\
\hline Del T & -0.14 & 0.04 & -3.28 & 0.01 \\
\hline Occupants & -0.08 & 0.06 & -1.23 & 0.24 \\
\hline
\end{tabular}

Parameter Estimates of the Empirical Model

\begin{tabular}{|c|c|}
\hline \multicolumn{2}{|c|}{ Regression Statistics } \\
\hline Multiple R & 0.92 \\
\hline R Square & 0.84 \\
\hline Adjusted R Square & 0.80 \\
\hline Standard Error & 0.26 \\
\hline Observations & 15 \\
\hline
\end{tabular}

Summary of Fit

\begin{tabular}{|c|c|c|c|c|c|}
\hline & Df & $\begin{array}{c}\text { Sum of } \\
\text { Squares }\end{array}$ & $\begin{array}{c}\text { Mean } \\
\text { Square }\end{array}$ & F & Significance F \\
\hline Regression & 3 & 4.09 & 1.36 & 19.64 & 0.0001 \\
\hline Residual & 11 & 0.76 & 0.07 & & \\
\hline Total & 14 & 4.85 & & & \\
\hline
\end{tabular}

Analysis of Variance (ANOVA) 
5. Regression Analysis: Response versus Area, Temperature Difference, Occupants, natural CFM

\begin{tabular}{|c|c|c|c|c|}
\hline Predictor & Coeff & SE Coeff & T & P \\
\hline Constant & 14.12 & 4.41 & 3.20 & 0.01 \\
\hline Area & -0.01 & 0.00 & -2.78 & 0.02 \\
\hline Del T & -0.13 & 0.05 & -2.80 & 0.02 \\
\hline Occupants & -0.11 & 0.08 & -1.38 & 0.20 \\
\hline Natural CFM & 0.01 & 0.01 & 0.68 & 0.51 \\
\hline
\end{tabular}

\section{Parameter Estimates of the Empirical Model}

\begin{tabular}{|c|c|}
\hline \multicolumn{2}{|c|}{ Regression Statistics } \\
\hline Multiple R & 0.92 \\
\hline R Square & 0.85 \\
\hline Adjusted R Square & 0.79 \\
\hline Standard Error & 0.27 \\
\hline Observations & 15 \\
\hline
\end{tabular}

Summary of Fit

\begin{tabular}{|c|c|c|c|c|c|}
\hline & Df & $\begin{array}{c}\text { Sum of } \\
\text { Squares }\end{array}$ & $\begin{array}{c}\text { Mean } \\
\text { Square }\end{array}$ & F & Significance F \\
\hline Regression & 4 & 4.12 & 1.03 & 14.13 & 0.0004 \\
\hline Residual & 10 & 0.73 & 0.07 & & \\
\hline Total & 14 & 4.85 & & & \\
\hline
\end{tabular}

Analysis of Variance (ANOVA) 
6. Regression Analysis: Response versus Area, Temperature Difference, Occupants, $\log$ (natural CFM)

\begin{tabular}{|c|c|c|c|c|}
\hline Predictor & Coeff & SE Coeff & T & P \\
\hline Constant & 12.34 & 6.16 & 2.00 & 0.07 \\
\hline Area & -0.01 & 0.00 & -2.23 & 0.05 \\
\hline Del T & -0.13 & 0.05 & -2.75 & 0.02 \\
\hline Occupants & -0.11 & 0.08 & -1.41 & 0.19 \\
\hline Ln(natural CFM) & 0.38 & 0.52 & 0.74 & 0.48 \\
\hline
\end{tabular}

Parameter Estimates of the Empirical Model

\begin{tabular}{|c|c|}
\hline \multicolumn{2}{|c|}{ Regression Statistics } \\
\hline Multiple R & 0.92 \\
\hline R Square & 0.85 \\
\hline Adjusted R Square & 0.79 \\
\hline Standard Error & 0.27 \\
\hline Observations & 15 \\
\hline
\end{tabular}

Summary of Fit

\begin{tabular}{|c|c|c|c|c|c|}
\hline & Df & $\begin{array}{c}\text { Sum of } \\
\text { Squares }\end{array}$ & $\begin{array}{c}\text { Mean } \\
\text { Square }\end{array}$ & F & Significance F \\
\hline Regression & 4 & 4.12 & 1.03 & 14.13 & 0.0004 \\
\hline Residual & 10 & 0.73 & 0.07 & & \\
\hline Total & 14 & 4.85 & & & \\
\hline
\end{tabular}

Analysis of Variance (ANOVA) 
7. Regression Analysis: Response versus Area, Temperature Difference, Occupants, $\log (\mathbf{A C H})$

\begin{tabular}{|c|c|c|c|c|}
\hline Predictor & Coeff & SE Coeff & T & P \\
\hline Constant & 13.69 & 4.67 & 2.93 & 0.02 \\
\hline Area & -0.01 & 0.01 & -1.89 & 0.09 \\
\hline Del T & -0.13 & 0.05 & -2.75 & 0.02 \\
\hline Occupants & -0.11 & 0.08 & -1.41 & 0.19 \\
\hline Ln(ACH) & 0.38 & 0.52 & 0.74 & 0.48 \\
\hline
\end{tabular}

Parameter Estimates of the Empirical Model

\begin{tabular}{|c|c|}
\hline \multicolumn{2}{|c|}{ Regression Statistics } \\
\hline Multiple R & 0.92 \\
\hline R Square & 0.85 \\
\hline Adjusted R Square & 0.79 \\
\hline Standard Error & 0.27 \\
\hline Observations & 15 \\
\hline
\end{tabular}

Summary of Fit

\begin{tabular}{|c|c|c|c|c|c|}
\hline & Df & $\begin{array}{c}\text { Sum of } \\
\text { Squares }\end{array}$ & $\begin{array}{c}\text { Mean } \\
\text { Square }\end{array}$ & F & Significance F \\
\hline Regression & 4 & 4.13 & 1.03 & 14.25 & 0.0004 \\
\hline Residual & 10 & 0.72 & 0.07 & & \\
\hline Total & 14 & 4.85 & & & \\
\hline
\end{tabular}

Analysis of Variance (ANOVA) 
Temperature Data Collected (Sample- Building 777, Apt\#205)

\begin{tabular}{|c|c|}
\hline \multirow{2}{*}{\multicolumn{2}{|c|}{$\begin{array}{l}\text { Date Time } \\
11 / 8 / 2013\end{array}$}} \\
\hline & \\
\hline $22: 53$ & 74.424 \\
\hline \multicolumn{2}{|l|}{ 11/8/2013 } \\
\hline $23: 53$ & 74.206 \\
\hline 11/9/2013 0:53 & 74.077 \\
\hline 11/9/2013 1:53 & 74.554 \\
\hline 11/9/2013 2:53 & 74.381 \\
\hline $11 / 9 / 20133: 53$ & 74.12 \\
\hline $11 / 9 / 20134: 53$ & 74.511 \\
\hline 11/9/2013 5:53 & 74.163 \\
\hline $11 / 9 / 20136: 53$ & 74.295 \\
\hline $11 / 9 / 20137: 53$ & 74.295 \\
\hline 11/9/2013 8:53 & 74.163 \\
\hline 11/9/2013 9:53 & 74.163 \\
\hline \multicolumn{2}{|l|}{ 11/9/2013 } \\
\hline $10: 53$ & 74.163 \\
\hline \multicolumn{2}{|l|}{$11 / 9 / 2013$} \\
\hline $11: 53$ & 74.163 \\
\hline \multicolumn{2}{|l|}{$11 / 9 / 2013$} \\
\hline $12: 53$ & 74.163 \\
\hline \multicolumn{2}{|l|}{ 11/9/2013 } \\
\hline $13: 53$ & 74.163 \\
\hline \multicolumn{2}{|l|}{$11 / 9 / 2013$} \\
\hline $14: 53$ & 74.511 \\
\hline \multicolumn{2}{|l|}{$11 / 9 / 2013$} \\
\hline $15: 53$ & 74.424 \\
\hline \multicolumn{2}{|l|}{$11 / 9 / 2013$} \\
\hline $16: 53$ & 74.25 \\
\hline \multicolumn{2}{|l|}{$11 / 9 / 2013$} \\
\hline $17: 53$ & 74.338 \\
\hline \multicolumn{2}{|l|}{$11 / 9 / 2013$} \\
\hline $18: 53$ & 74.338 \\
\hline \multicolumn{2}{|l|}{$11 / 9 / 2013$} \\
\hline $19: 53$ & 74.12 \\
\hline \multicolumn{2}{|l|}{$11 / 9 / 2013$} \\
\hline $20: 53$ & 74.295 \\
\hline \multicolumn{2}{|l|}{$11 / 9 / 2013$} \\
\hline $21: 53$ & 74.163 \\
\hline \multicolumn{2}{|l|}{$11 / 9 / 2013$} \\
\hline $22: 53$ & 74.424 \\
\hline
\end{tabular}




\begin{tabular}{|c|c|}
\hline $11 / 9 / 2013$ & \\
\hline $23: 53$ & 74.163 \\
\hline $11 / 10 / 2013$ & \\
\hline $0: 53$ & 74.338 \\
\hline $11 / 10 / 2013$ & \\
\hline 1:53 & 74.424 \\
\hline $11 / 10 / 2013$ & \\
\hline $2: 53$ & 74.163 \\
\hline $11 / 10 / 2013$ & \\
\hline $3: 53$ & 74.467 \\
\hline $11 / 10 / 2013$ & \\
\hline $4: 53$ & 74.077 \\
\hline $11 / 10 / 2013$ & \\
\hline $5: 53$ & 74.12 \\
\hline $11 / 10 / 2013$ & \\
\hline $6: 53$ & 74.163 \\
\hline $11 / 10 / 2013$ & \\
\hline $7: 53$ & 74.25 \\
\hline $11 / 10 / 2013$ & \\
\hline $8: 53$ & 74.511 \\
\hline $11 / 10 / 2013$ & \\
\hline $9: 53$ & 74.077 \\
\hline $11 / 10 / 2013$ & \\
\hline $10: 53$ & 74.467 \\
\hline $11 / 10 / 2013$ & \\
\hline $11: 53$ & 74.163 \\
\hline $11 / 10 / 2013$ & \\
\hline $12: 53$ & 74.163 \\
\hline $11 / 10 / 2013$ & \\
\hline $13: 53$ & 74.338 \\
\hline $11 / 10 / 2013$ & \\
\hline $14: 53$ & 74.163 \\
\hline $11 / 10 / 2013$ & \\
\hline $15: 53$ & 74.467 \\
\hline $11 / 10 / 2013$ & \\
\hline $16: 53$ & 74.12 \\
\hline $11 / 10 / 2013$ & \\
\hline $17: 53$ & 74.381 \\
\hline $11 / 10 / 2013$ & \\
\hline $18: 53$ & 74.424 \\
\hline $11 / 10 / 2013$ & \\
\hline 19:53 & 74.338 \\
\hline $11 / 10 / 2013$ & \\
\hline $20: 53$ & 74.554 \\
\hline $11 / 10 / 2013$ & \\
\hline 21:53 & 74.554 \\
\hline $11 / 10 / 2013$ & 74.381 \\
\hline
\end{tabular}


22:53

$11 / 10 / 2013$

23:53

74.12

$11 / 11 / 2013$

0:53

74.163

$11 / 11 / 2013$

1:53

74.163

$11 / 11 / 2013$

2:53

74.12

$11 / 11 / 2013$

3:53

74.077

$11 / 11 / 2013$

4:53

74.077

$11 / 11 / 2013$

5:53

74.424

$11 / 11 / 2013$

6:53

74.12

$11 / 11 / 2013$

7:53

74.077

$11 / 11 / 2013$

8:53

74.511

$11 / 11 / 2013$

9:53

74.467

$11 / 11 / 2013$

10:53

74.597

$11 / 11 / 2013$

11:53

74.64

$11 / 11 / 2013$

12:53

74.077

$11 / 11 / 2013$

13:53

74.338

$11 / 11 / 2013$

14:53

74.338

$11 / 11 / 2013$

15:53

74.25

$11 / 11 / 2013$

16:53

73.861

$11 / 11 / 2013$

17:53

73.126

$11 / 11 / 2013$

18:53

72.48

$11 / 11 / 2013$

19:53

72.007

$11 / 11 / 2013$

20:53

71.62

$11 / 11 / 2013$

21:53

74.856 
$11 / 11 / 2013$

22:53

75.204

$11 / 11 / 2013$

23:53

75.29

$11 / 12 / 2013$

$0: 53$

75.463

$11 / 12 / 2013$

1:53

75.551

$11 / 12 / 2013$

2:53

75.117

$11 / 12 / 2013$

3:53

75.463

$11 / 12 / 2013$

4:53

75.117

$11 / 12 / 2013$

5:53

75.029

$11 / 12 / 2013$

6:53

75.333

$11 / 12 / 2013$

7:53

75.204

$11 / 12 / 2013$

8:53

75.029

$11 / 12 / 2013$

9:53

75.16

$11 / 12 / 2013$

10:53

75.376

$11 / 12 / 2013$

11:53

75.074

$11 / 12 / 2013$

12:53

74.163

$11 / 12 / 2013$

13:53

74.163

$11 / 12 / 2013$

$14: 53$

72.955

$11 / 12 / 2013$

15:53

71.877

$11 / 12 / 2013$

$16: 53$

70.974

$11 / 12 / 2013$

17:53

70.286

$11 / 12 / 2013$

18:53

69.685

$11 / 12 / 2013$

19:53

69.643

$11 / 12 / 2013$

20:53

73.731

$11 / 12 / 2013$

76.246 


\begin{tabular}{|c|c|}
\hline $21: 53$ & \\
\hline $11 / 12 / 2013$ & \\
\hline $22: 53$ & 76.681 \\
\hline $11 / 12 / 2013$ & \\
\hline $23: 53$ & 76.375 \\
\hline $11 / 13 / 2013$ & \\
\hline $0: 53$ & 76.375 \\
\hline $11 / 13 / 2013$ & \\
\hline $1: 53$ & 76.464 \\
\hline $11 / 13 / 2013$ & \\
\hline $2: 53$ & 76.071 \\
\hline $11 / 13 / 2013$ & \\
\hline $3: 53$ & 76.114 \\
\hline $11 / 13 / 2013$ & \\
\hline $4: 53$ & 76.203 \\
\hline $11 / 13 / 2013$ & \\
\hline $5: 53$ & 76.028 \\
\hline $11 / 13 / 2013$ & \\
\hline $6: 53$ & 76.246 \\
\hline $11 / 13 / 2013$ & \\
\hline $7: 53$ & 76.071 \\
\hline $11 / 13 / 2013$ & \\
\hline $8: 53$ & 74.943 \\
\hline $11 / 13 / 2013$ & \\
\hline $9: 53$ & 74.163 \\
\hline $11 / 13 / 2013$ & \\
\hline $10: 53$ & 73.645 \\
\hline $11 / 13 / 2013$ & \\
\hline $11: 53$ & 72.997 \\
\hline $11 / 13 / 2013$ & \\
\hline $12: 53$ & 72.523 \\
\hline $11 / 13 / 2013$ & \\
\hline $13: 53$ & 72.007 \\
\hline $11 / 13 / 2013$ & \\
\hline $14: 53$ & 71.62 \\
\hline $11 / 13 / 2013$ & \\
\hline $15: 53$ & 71.964 \\
\hline $11 / 13 / 2013$ & \\
\hline $16: 53$ & 72.007 \\
\hline $11 / 13 / 2013$ & \\
\hline $17: 53$ & 71.404 \\
\hline $11 / 13 / 2013$ & \\
\hline $18: 53$ & 70.887 \\
\hline $11 / 13 / 2013$ & \\
\hline 19:53 & 70.459 \\
\hline $11 / 13 / 2013$ & \\
\hline $20: 53$ & 70.072 \\
\hline
\end{tabular}


$11 / 13 / 2013$

21:53

70.201

$11 / 13 / 2013$

22:53

70.587

$11 / 13 / 2013$

23:53

70.372

$11 / 14 / 2013$

0:53

74.554

$11 / 14 / 2013$

1:53

75.16

$11 / 14 / 2013$

2:53

73.818

$11 / 14 / 2013$

3:53

73.299

$11 / 14 / 2013$

4:53

72.955

$11 / 14 / 2013$

5:53

73.126

$11 / 14 / 2013$

6:53

73.429

$11 / 14 / 2013$

7:53

73.04

$11 / 14 / 2013$

8:53

73.083

$11 / 14 / 2013$

9:53

73.342

$11 / 14 / 2013$

10:53

73.299

$11 / 14 / 2013$

11:53

72.912

$11 / 14 / 2013$

$12: 53$

73.213

$11 / 14 / 2013$

13:53

73.04

$11 / 14 / 2013$

$14: 53$

73.04

$11 / 14 / 2013$

15:53

73.213

$11 / 14 / 2013$

$16: 53$

73.04

$11 / 14 / 2013$

17:53

72.48

$11 / 14 / 2013$

18:53

71.877

$11 / 14 / 2013$

19:53

71.964

$11 / 14 / 2013$

75.204 
20:53

$11 / 14 / 2013$

21:53

75.204

$11 / 14 / 2013$

22:53

74.338

$11 / 14 / 2013$

23:53

74.077

$11 / 15 / 2013$

$0: 53$

74.12

$11 / 15 / 2013$

1:53

73.947

$11 / 15 / 2013$

2:53

74.295

$11 / 15 / 2013$

3:53

73.904

$11 / 15 / 2013$

4:53

74.034

$11 / 15 / 2013$

5:53

74.295

$11 / 15 / 2013$

6:53

74.077

$11 / 15 / 2013$

7:53

73.99

$11 / 15 / 2013$

8:53

74.338

$11 / 15 / 2013$

9:53

74.163

$11 / 15 / 2013$

10:53

73.947

$11 / 15 / 2013$

11:53

74.12

$11 / 15 / 2013$

$12: 53$

74.295

$11 / 15 / 2013$

13:53

74.163

$11 / 15 / 2013$

14:53

74.163

$11 / 15 / 2013$

15:53

74.077

$11 / 15 / 2013$

$16: 53$

74.424

$11 / 15 / 2013$

17:53

74.12

$11 / 15 / 2013$

18:53

74.163

$11 / 15 / 2013$

19:53

74.424 


\begin{tabular}{|c|c|}
\hline \multicolumn{2}{|l|}{$11 / 15 / 2013$} \\
\hline 20:53 & 74.25 \\
\hline \multicolumn{2}{|l|}{$11 / 15 / 2013$} \\
\hline 21:53 & 74.163 \\
\hline \multicolumn{2}{|l|}{$11 / 15 / 2013$} \\
\hline $22: 53$ & 74.163 \\
\hline \multicolumn{2}{|l|}{$11 / 15 / 2013$} \\
\hline 23:53 & 74.077 \\
\hline \multicolumn{2}{|l|}{$11 / 16 / 2013$} \\
\hline $0: 53$ & 74.381 \\
\hline \multicolumn{2}{|l|}{$11 / 16 / 2013$} \\
\hline 1:53 & 74.163 \\
\hline \multicolumn{2}{|l|}{$11 / 16 / 2013$} \\
\hline $2: 53$ & 74.424 \\
\hline \multicolumn{2}{|l|}{$11 / 16 / 2013$} \\
\hline $3: 53$ & 74.12 \\
\hline \multicolumn{2}{|l|}{$11 / 16 / 2013$} \\
\hline $4: 53$ & 74.511 \\
\hline \multicolumn{2}{|l|}{$11 / 16 / 2013$} \\
\hline $5: 53$ & 74.163 \\
\hline \multicolumn{2}{|l|}{$11 / 16 / 2013$} \\
\hline $6: 53$ & 74.163 \\
\hline \multicolumn{2}{|l|}{$11 / 16 / 2013$} \\
\hline 7:53 & 74.163 \\
\hline \multicolumn{2}{|l|}{$11 / 16 / 2013$} \\
\hline $8: 53$ & 74.338 \\
\hline \multicolumn{2}{|l|}{$11 / 16 / 2013$} \\
\hline $9: 53$ & 74.077 \\
\hline \multicolumn{2}{|l|}{$11 / 16 / 2013$} \\
\hline $10: 53$ & 74.597 \\
\hline \multicolumn{2}{|l|}{$11 / 16 / 2013$} \\
\hline 11:53 & 74.424 \\
\hline \multicolumn{2}{|l|}{$11 / 16 / 2013$} \\
\hline $12: 53$ & 74.25 \\
\hline \multicolumn{2}{|l|}{$11 / 16 / 2013$} \\
\hline $13: 53$ & 74.683 \\
\hline \multicolumn{2}{|l|}{$11 / 16 / 2013$} \\
\hline $14: 53$ & 74.727 \\
\hline \multicolumn{2}{|l|}{$11 / 16 / 2013$} \\
\hline $15: 53$ & 74.683 \\
\hline \multicolumn{2}{|l|}{$11 / 16 / 2013$} \\
\hline $16: 53$ & 80.316 \\
\hline
\end{tabular}




\section{References}

1. http://www1.eere.energy.gov/consumer/tips/m/home_energy.html

2. US DOE fact sheet

3. Industrial Sector Energy Consumption. http://www.eia.doe.gov/totalenergy/data/annual/\#consumption (accessed January 17, 2011).

4. Building Energy Data book http://buildingsdatabook.eren.doe.gov/default.aspx (accessed January, 2014)

5. ASHRAE 90.2

http://www.energyefficiencymatters.org/what-is-ashrae-standard-90-2 (accessed January, 2014)

6. http://yanpage.narod.ru/NCMA_TEKs/TEKs/Wce2743723fb62.htm\# (accessed January, 2014)

7. Insulations http://homeenergysaver.lbl.gov/consumer/faqs\#g3 (accessed January, 2014)

8. Set Back Temperature Control - Utilities Savings Factsheet (http://portal.ncdenr.org/c/document_library/get_file?uuid=6f993424-2f12-459c-8526099318b59c3d\&groupId=38322)

9. King, J.C., Trechsel, R.Heinz, Building Air Change Rate and Infiltration Measurements: A Symposium, Issue 719

10. Regression Analysis http://www.stat.yale.edu/Courses/1997-98/101/linmult.htm (accessed January, 2014)

11. http://reliawiki.org/index.php/Multiple_Linear_Regression_Analysis (accessed January, 2014)

12. EnerWin Software Manual (1996). Energy Calculation for Windows, Texas A and M University, College Station, TX, USA

13. Al-Homoud, S.Mohammad, 2003, "The Effectiveness of Thermal Insulation in Different Types of Buildings in Hot Climates", Journal of Thermal Envelope and Building Science , pp. 235-247 
14. Kashiwagi, Dean.T, Moor, C.William, 1993, "The Relationship between Energy Cost and Conservation Measures, Building Design and Insulation Levels", Journal of Building Physics, Vol 16 no. 4, pp. 375-394

15. Porte, M, 1985, "Competitive Advantage, Creating and Sustaining Superior Performance", NY: The Free Press

16. Mattsson, Bjorn, 2006, "The influence of wind speed, terrain and ventilation system on the air change rate of a single-family house", Energy, 31(5), pp 719-731

17. Hilado, J C, 1979, "Laboratory Method for Determining Effectiveness Of Thermal Insulation", Journal of Building Physics, pp- 3-32

18. Asadi, Somayeh, 2011, "Thesis: Evaluation of the thermal performance and cost effectiveness of radiant barrier thermal insulation materials in residential construction", Louisiana State University

19. Amery, A.F., Kippenhan, C.J., "A long term study of residential home heating consumption and the effect of occupant behavior on homes in the Pacific Northwest constructed according to improved thermal standards", Energy, 31, pp: 677-693

20. Tumma, Preecha, Chirarattananon, Surapong, Hien, Vu Duc , Chaiwiwatworakul, Pipat, Rakkwamsuk, Pattana, 2013, "Thermal Performance of insulated walls enclosing residential spaces in Thailand", Energy and Buildings, 61, pp: 323-332

21. Yao, Runming, Steemers, Koen, 2004, "A method of formulating energy load profile for domestic buildings in the UK", Energy and Buildings, 37, pp-663-671

22. Carlos,J, Lamberts, R, 2008, "Development of envelope efficiency labels for commercial buildings: Effect of different variables on electricity consumption", Energy and Buildings, 40(11)

23. Wojdyga, K, 2008, "An influence of weather conditions on heat demand in district heating systems", Energy and Buildings, 40

24. Mattsson, B, 2004 "The influence of wind speed, terrain and ventilation system on the air change rate of a single-family house", Proceedings of ASME-ZSIS international thermal science seminar II, Bled, Slovenia

25. Chung, W, Hui, Y.V., 2009 "A study of energy efficiency of private buildings $n$ Hong Kong”, Energy and Buildings, 41(6), pp:696-701 